\title{
LEGIBILITY
}

A major purpose of the Technical Information Center is to provide the broadest dissemination possible of information contained in DOE's Research and Development Reports to business, industry, the academic community, and federal, state and local governments.

Although a small portion of this report is not reproducible, it is being made available to expedite the availability of information on the research discussed herein. 


\section{Technology App'ications Bulletins}

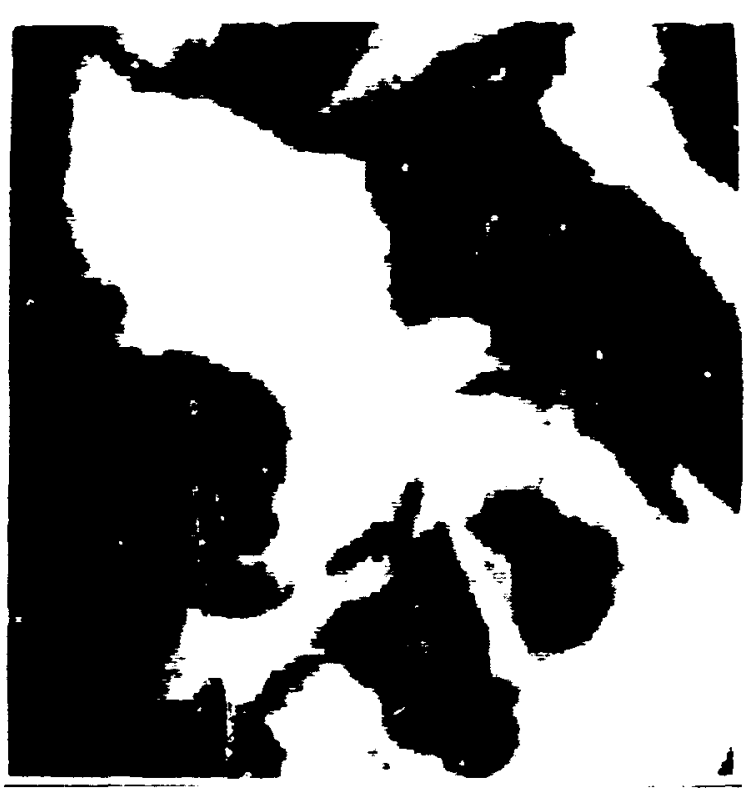

ON THE COVES: Color compoevite dipital $X$-rev imeco of the clementul distributions in a malechite ore. Rac represents the manganese distribution. green represents the iron diatribution. and blue represents the copper dietribution. Date for constructing the imege, which spans 1- $\mathrm{mm}^{2}$ erea of the spocimen. were taken with the HkXPP-5. a iigh-resolution X-ray microprobe. The color composite is useful in determining the extent of essociation of the elements. (Cover imege by Donald A. Cerpenter, Y-12 Plant Development Division.)

Office of Tochnology Applications

Vice Prasident

W. W. Carpentizr

\section{Information Services}

Manager of Technctogr Transter

Donald W. Jarec'

Secretary

Pauine Hughes

\author{
Publication Division \\ Editor \\ Walter Koncinsk!. Ji. \\ Typography \\ Sandi Lyttle \\ Makeisp \\ Larry Davis \\ Bob Eldridge
}

\section{Graphics Division \\ Leon Smith \\ Larry Bohannan \\ Cover Dosign \\ Vickie L. Comer}

Martin Marietta Energy Systems. Inc.

(Energy Systems). operates five facilities for the U.S. Department of Energy (DOE):

- the Oak Ridge National Laboratory (ORNL), which is a large. multidisciplinary research and development (R\&D) center whose primary mission is enorgy research;

- the Oak Ridge $Y-12$ Plant, which engages in defense research, development, and production; and

- the uranium-enrichment plants at Oak Ridge; Paducah, Kentucky; and Portsmouth, Ohio.

Much of the research carried out at these facilities is of interest to industry and to state or local governments. To make information about this research availahle, the Energy Systems Office of Technology Applications publishes brief descriptions of selected technologies and reports. These techriology applications bulletins describe the new technology and inform the reader about how to obtain further information, gain access to technical resources, and initiate direct contact with Energy Systems researchers.

Office of Technology Applications

Information Services

Martin Marietta Energy Systems, Inc.

P.O. Box 2008

Oak Ricige. TN 37831-3257

Telephone: (615) 574-4192; FTS 624-4192 


\section{CONTENTS}

TECHNOLOGY APPLICATIONS NEWS

ARTIFICLAL INTELLEENCE, ROBOTICS, AND MANUFACT'RANG PROCESSES

Agorithms for Efficient Use of Mutiprocessor Hardware

MEASUREMENTS AND CONTROLS

HAXRP-5 High-Resolution X-ray Microprobe

Fracture-Mechanics Anabysis on a Distributed-Memory Paraled Processor $\ldots \ldots \ldots$

Linear Harmonic Anahsis of Free-Piston Stirling Engines $\ldots \ldots \ldots \ldots \ldots$

Single-Board Microcontroller Sutable for Rapid Prototyping $\ldots \ldots \ldots \ldots \ldots$

Demodulation Circuit for ac Motor Current Signature Anahsis . . . . . . . . . . . . . . . 31

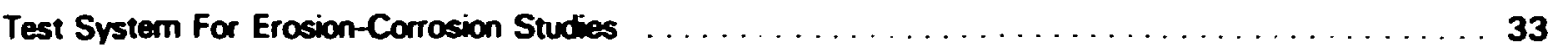

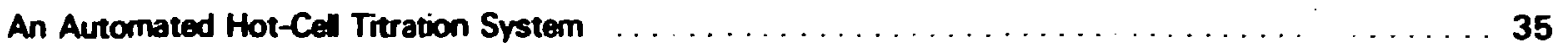

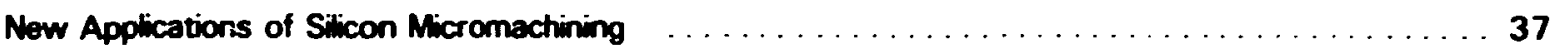

Instrumentation System for Precision Measurements of Flow Vectors $\ldots \ldots \ldots . \ldots$

MEOKCAL AND BLOMEDUCAL TECHNOLOGY

Radiolabeling Technique for Earty Cancer Detection $\ldots \ldots \ldots \ldots \ldots \ldots \ldots \ldots$

\section{ENERGY CONSERVATION}

Triple-Effect Absorption Chiller Using Two Refrigeration Circuits . . . . . . . . . . . . . . 43

Seven-Effect Absc ption Chiller Using Three Refrigeration Circuits $\ldots \ldots \ldots \ldots$

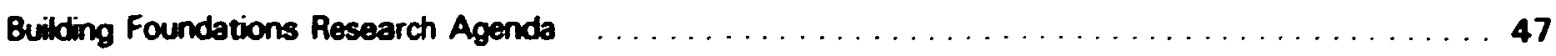

An Enhanced Computer Program for Modeling Absorption Heat Pump Systems . . . . . . . . . . . . 49

Infiltration Reduction for Single-Famity Houses $\ldots \ldots \ldots \ldots \ldots \ldots \ldots$

Occupant Evaluation of Commercial Office Lighting $\ldots \ldots \ldots \ldots \ldots \ldots$

Documentation for Residential Reference House Energy Demand Model $\ldots \ldots \ldots 5$

The Princeton Scorekeeping Method Compared with Energy End-Use Load Data . . . . . . . . . . 57

TRANSPORTATION

Review of Nonresidential Transportation Energy Use Data . . . . . . . . . . . . . . . . . . $5 \mathbf{5 9}$

Technology Transfer for DOE's Office of Transportation Systems $\ldots \ldots \ldots \ldots 1$

\section{ENERGY PRODUCTION}

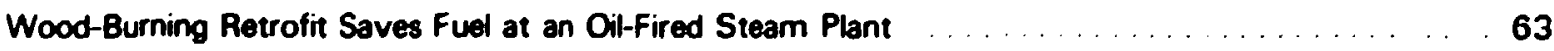

Retiability Studies for Compressed-Gas-Insulated Apparatus . . . . . . . . . . . . . . . . . 65

Assessment of Material Requirements for Advanced Steam Cycle Systems . . . . . . . . . . . . . 67

Study of Solai Power Supply System at Mississippi County Community College . . . . . . . . . . . . 69

An All-Metal Rer ntrant Vacuum feedthrough $\ldots \ldots \ldots \ldots \ldots \ldots \ldots$

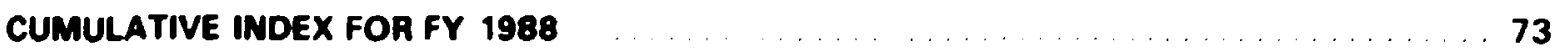




\section{Alvin W. Trivelpiece Named ORNL Director}

Energy Systems has announced the appointment of Alvin W. Trivelpiece as director of ORNL. He also serves a.s a vice president of Energy Systems, which manages four other energy-related facilities in additior to ORNL. Dr. Trivelpiece assumed full responsibility for his new appointments oi January 1.

In announcing the appointment, Energy Systems President Clyde C. Hopkins said. "We are extremely fortunate to have Dr. Trivelpiece lead our team at ORNL. His experience in acadernics, industry, and governmen: will enable him to provide strong guidance in both strategic planning and the implementation of science and technology programs. His strong scientific and engineering credentials will ensure the commitment to high standards within the Laboratory, and his personal character and leadership will provide new direction for ORNL."

Before joining ORNL. Dr. Trivelpiece was executive officer of the American Association for the Advancement of Science. He has also been the director of DOE's Office of Energy Research; corperate vice president for Science Applications, Inc.; vice president for engineering and research at Maxwell Laboratories, Inc.; professor of physics at the University of Maryland; and assistant director for research in the U.S. Atomic Energy Commission's Division of Controlles Thermonuclear Research.

Dr. Trivelpiece said that he accepted the position with Energy Systems because "it's an opportunity to be closer to hardware and science, which is really where my background is." An advocate of the Superconducting Super Collider.

Dr. Trivelpiece has stressed the importance of basic research and technology transfer to the well-being of the U.S. economy. (Q:ioted with permission from Energy Daily.

October 6, 1988.)

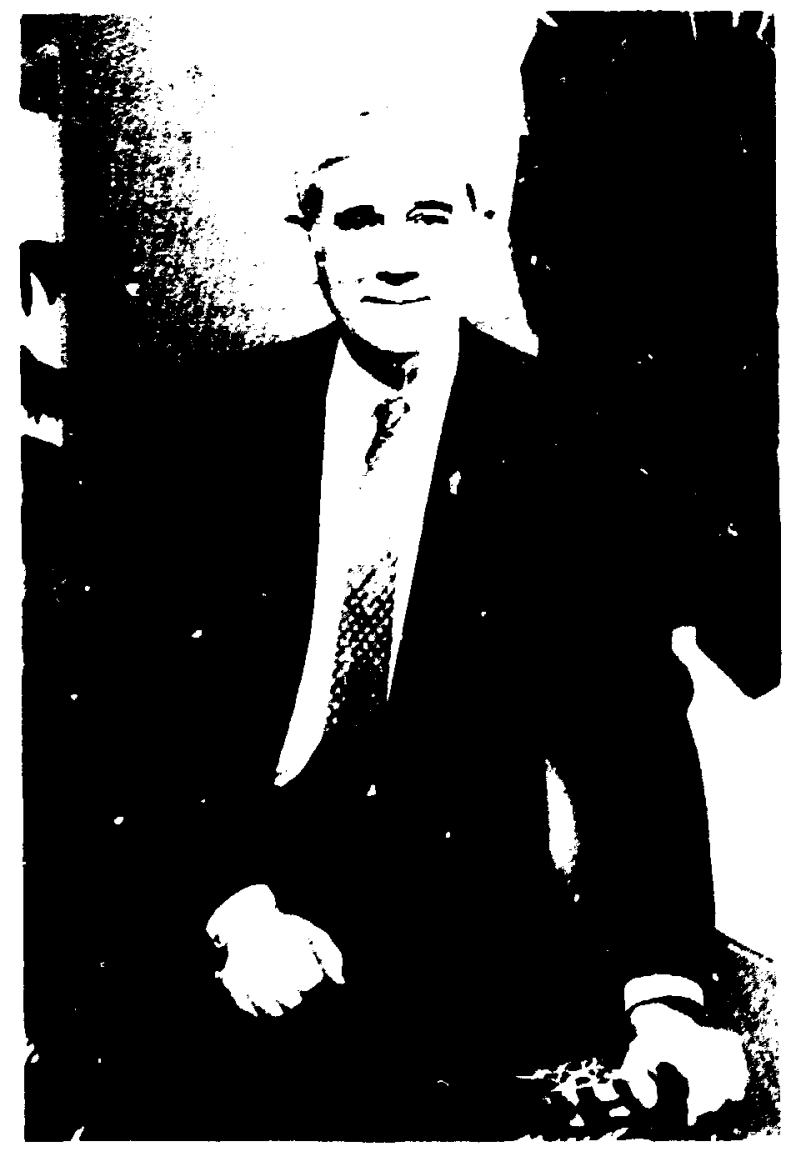




\section{R\&D 100 Awards}

Each fall. Resejrch \& Development magazine recognizes the top 100 technical innovations of the year with its R\&D 100 awards (formerly the HR 100 awards). The winners are selected from thousands of scien:ific and technical achievements workdwide. They arc chosen because of their importance, unique ress, and usefulness to mankind. This year, the OPSNET computer architecture. developed at ORNL, and the HRXRP-5 high-resolution X-ray microprobe, developed at the Oak Ridge Y-12 Plant, both won R\&D 100 awards. Their developers were honored on September 22 in ceremonies at Chicago's Museum of Science and Industry.

\section{The ORSNET Parallel Comp ster}

\section{Avoilable for Licensing}

The OPSNET parallel computer was developed by John D. Allen, Jr.. and Phip L. Butier of ORNL's Instrumentation and Controls Division. It executes the OPS5 expert system language. which is used to emulate the decision-making processes of experts in fields such as medical diagnosis, organic chemical synthesis, and intelligent robot control. Previously, uses of expert systams for real-time process control have been limited by stow execution speeds, even with powerful mainframe computers. OPSNET outperforms conventional computer architectures and does so at a fraction of the cost of other parallet machines.

Ask for bulletin Number 650.

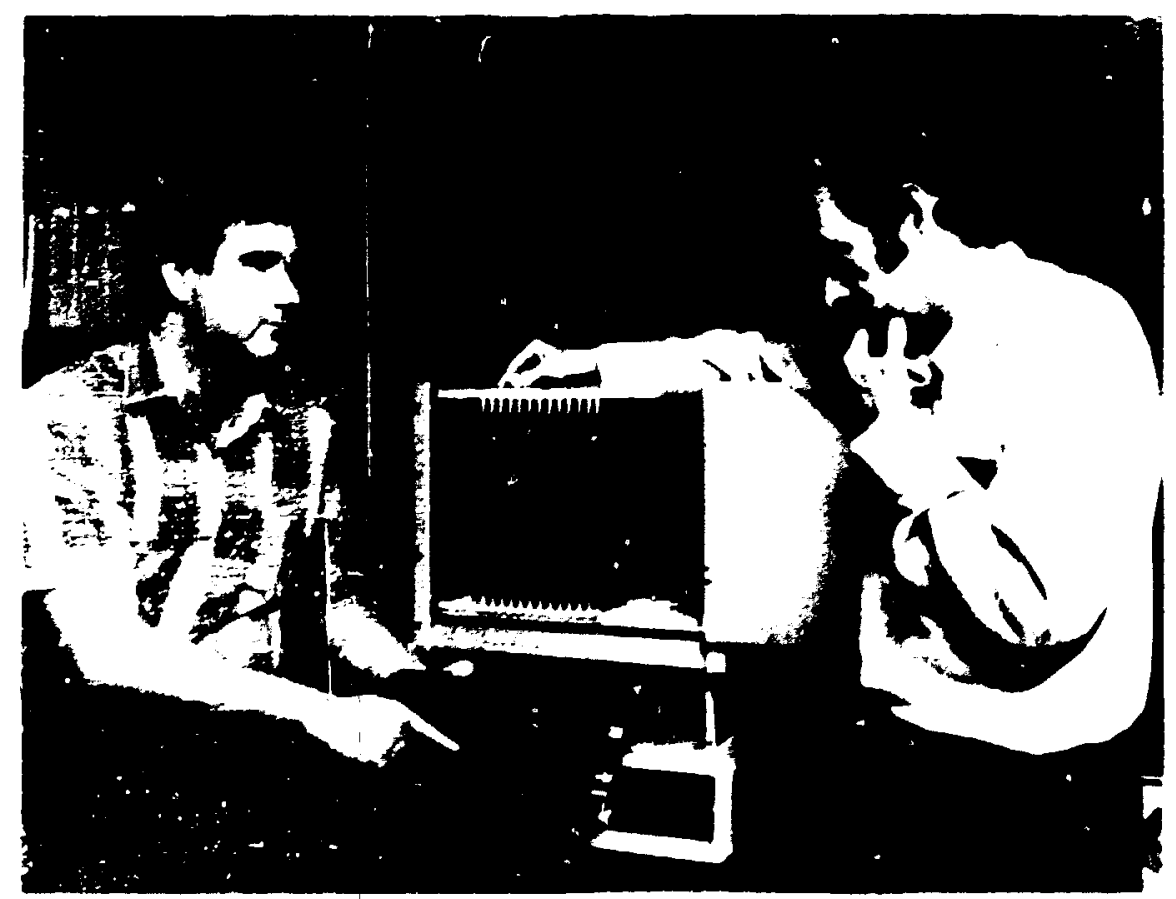

Philip L. Butbor flefte and Jahn H. Allon. Jr., of OANL's Inatrumenestion and Controds Division, with the OPSNET machine. 
The HRXRP-5 was developed by Donald A. Carpenter, Roger L. Lawson, Mark A. Taytor, Gary M. Haney, and Karl Z. Morgan of the Y-12 Plant Development Division. It is an analytical device that produces color images of chemical-etement distributions in metal, ceramic, composite, biological, and geological specimens. Typically. analyses with the HRXRP-5 are carried out in air with little or no sample preparation. Analysis time is fast enough to maintain a high sample throughput, and relatively large specimens can be analyzed because no vacuum chamber is required.

See Bulletin Number 674 in this issue.

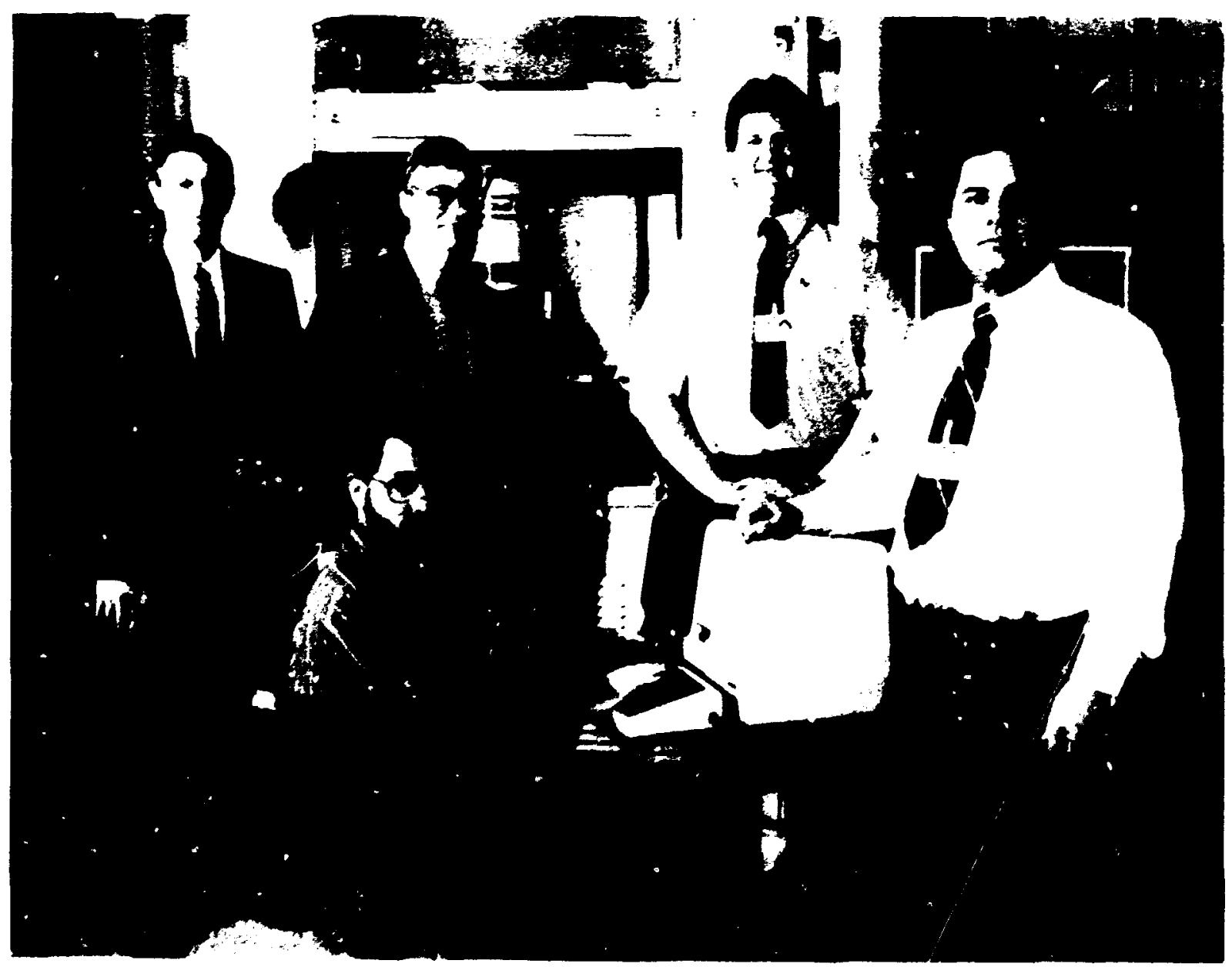

The dovalopors of the HAXRP-6 X-ray microprobe (loft to right): Karl Morgan, Desn Carponter. Gary Harvey. Mark Toytor (easted), and Roger Loweon. 
ORNL's Program Planning and Analysis Office has continued to sponsor speakers in its "U.S. Global Competitiveness and the National Laboratories" lecture series. Four speakers have appeared since Senator Lim Sasser began the program with a keynote address in February 1988. These speakers offered their observations about the relationship between scientific research and industrial applications. They presented specific examples of how private industries can reap the benefits of Uasic research.

Dr. Richard N. Foster, director of the McKinsey \& Company management consulting firm, gave a presentation based on his widely acclaimed book. Innovation: The Attacker's Advantage. According to Foster, the lifetime of a developing technology is finite and limited by the amount of R\&D needed to fully realize that technolugy's potential. The national laboratories can help industrial managers estimate the value of a technology during its maturation.

Dr. Siegfried S. Hecker, director of the Los Alamos National Laboratory, sought to clarify the identities of national laboratories and to define their role in the U.S. bid for global competitiveness. He described a new, precompetitive way for DOE laboratories to work with private industry, using the new superconductivity pilot center program as an example.

Dr. Fumio Kodama, professor of innovation policy at Saitama University and director of Japan's National Institute of Science and Technology Policy, spoke ahout techrological diversification in Japan. He explained how Japan's "research association scheme" has enabled corpeting private industries to collaborate successfully on R\&D projects.

The fourth speaker was Dr. Ralph E. Gomory, senior vice president for science and technology for IBM and Research \& Development magazine's choice for "Scientist of the Year" in 1987. Speaking from the corporate point of view. Dr. Gomory described the relationship between scientific research and the manufacturirig and development of commercial products. 
Foster addressed technological innovation from the standpoint of a corporate executive officer whose task it is to maximize the return from product R\&D. According to Foster, every technological innovation has its limits, and the cost of improved performance increases as that limit is approached. The size of the gap between the current state of the art and what is unknown about the new technology determines both the "level" and the useful lifetime of that technology. A large gap indicates a high technology, and its useful lifetime lies within the time it takes to close that gap.

A student of the science historian Thomas Kuhn, Foster has observed that technological innovation proceeds in a discontinuous, "revolutionary" manner although it may be perceived as a smooth, "evolutionary" process. For example, the replacement of the vacuum tube by the

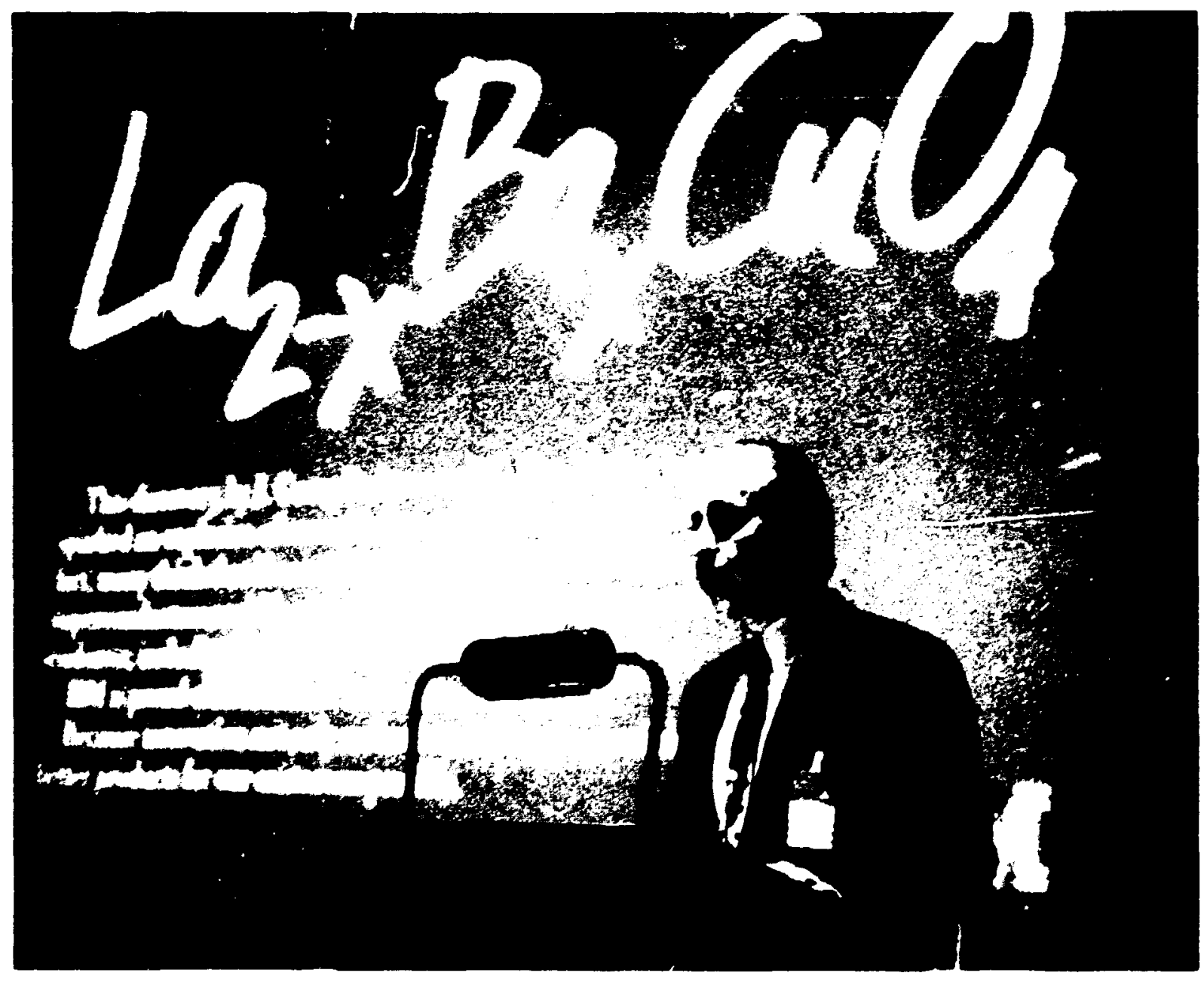

Dr. Richard W. Foster, director of MeKineey 2 Compeny: "I think the national labe heve e unique robe to play in the economic lendecaps by telling our people whot these limits of performence are and why. H's basic science question." 
transistor could be interpreted as an evolutionary step for the electronics industry generally.

However, for the companies involved, it was a revolution in which the dominant companies lost to newcomers who were trained and tooled up for the new technology. Based on many examples like this one. Foster has concluded that, "Untike in conventional military warfare, the attacker has the advantage in the markeiplace. . . . The technological productivity of the new technology is so many times superior to that of the older technology that you start with an intred economic advantage."

The lifetime of a technology follows an arc that climbs slowly at first, i.ven steadily and quickly as increasingly difficult problems affecting its performance are solved. This progression will continue until the problems become so difficult that the gains in pertormance are no longer worth the effort that they require. At this point, it is an opportune time for an innovative technology (such as transistors) to replace the mature technology (vacuum tubes).

According to Foster, corporate executive officers need to recognize and gauge the upper limit of a developing technology so they can manage its useful lifetime responsibly. However, scientists close to the basic research are better able to assess a new technology's limitations and can serve as useful advisors to decision-makers in industry: "I think the national labs have a unique role to play in the economic landscape by telling our people what these limits of performance are and why. li's a basic science question." 


\section{Superconductivity Pilot Centers}

Hecker stated his perception of the current and future role of national laboratories in the technology transfer process. Technology transfer from the national laboratories to private industries has been strongly encouraged by the federal government. However, according to Hecker, the current method of technology transfer has frustrated both the laboratories and industry because it is being handled like a sales transaction and because it is governed by a daunting amount of bureaucracy.

Hecker said that "technology has been treated too much as a commodity that can be bought or sold or passed around when, in fact, it has to be woven into the fabric of commercial innovation." According to him, the relationship between the laboratories and industries ought to be a partnership in which the three principal partners in the technology transfer process have definite obligations. The laboratories must recognize that technology development should be guided by market pull. Industry, in turn, must recognize the benefits of collaborative technology development in the precommercial, precompetitive stages that will benefit U.S. industry as a whole; the laboratories are not now and should not become "job shops" for individual companies. Federal agencies need to mirimize bureaucracy and nurture these partnerships.

Most of the federally funded laboratories were started in response to war or crisis and continue to be well suited for high-risk, goal-oriented projects. As Hecker put it, "We are often

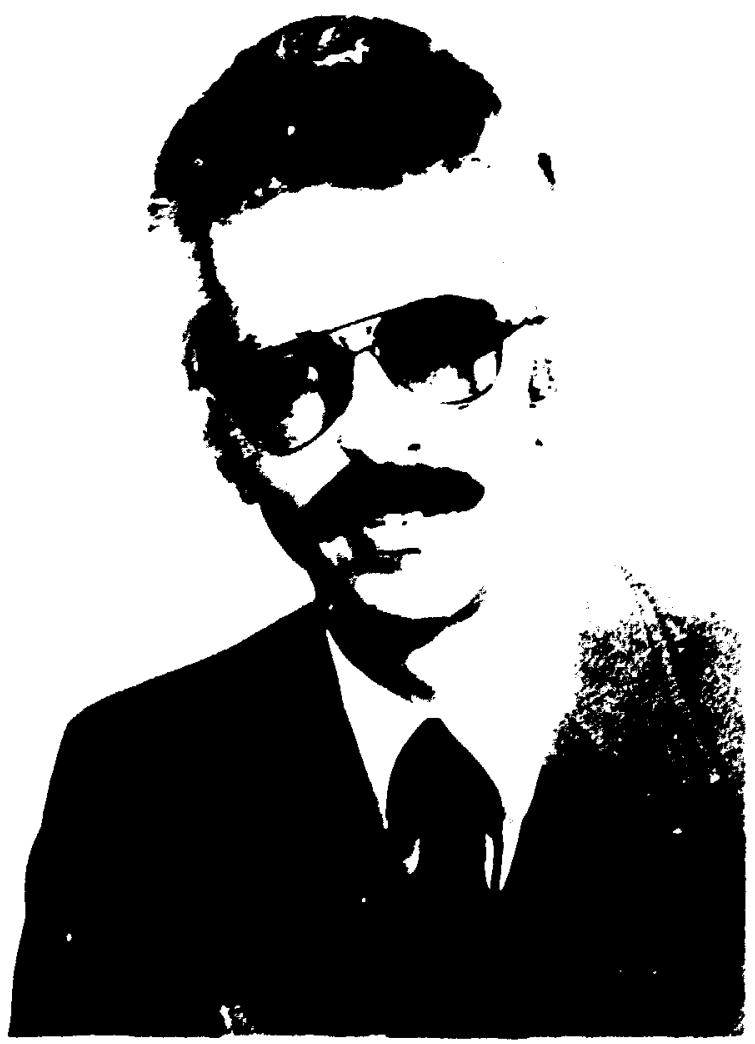

Dr. Siegfried 8. Hecker, director, Los Alemos National Leboratory: "Technology has been treated too much as a commodity that can be bought or sold or pasead around, whon in fect it has to be woven into the fabric of commercial innovation." 
assigned responsibilities beyond any person's known competence." One major responsibility currently assigned to the national laboratories is to identify and pursue strategic technologies suitable for collaborative R\&D.

Hecker described the new superconductivity pilot centers as a project that will demonstrate a precompetitive collaboration on a strategic technology. Applied high-temperature superconductivity is a new, high-risk and potentially highly licrative field. The new pilot centers at ORNL. Los Alamos, and Argonne will focus on generic technology development and collaboration with industry.

An agreement that will expedite this experimental program is being finalized by DOE. The agreement will provide the criteria for joint R\&D projects between industry and the national laboratories. These criteria include collaborative and cost-shared research, protection for proprietary information, exclusive patent and use rights, and licensing provisions for laboratoryowned intellectual property. 
Kodama described his research into the technological diversification that has taken place recently in Japanese industry. 5y analyzing an extensive data base maintained by the Japanese government, he has devised methods to quantify the influence of R\&D investments on economic restructuring in Japan. [Details of this analysis can be found in Dr. Kodama's article, "Technological Diversification of Japanese Industry," Science 23314761), 291-96 (July 18, 1986).]

Dr. Kodama has observed among Japanese corporations a "paradigm change," which has taken place since 1985. Although once primarily oriented toward production, Japanese companies now spend much more money on R\&D than on capital investment. He redefined "corporation" to suit what he has observed happening in Japan: The corporation could be said to be sisifting from being a place for production to being a place for thinking: thinking for survival, thinking for the future." The Japanese government has taken steps to exploit this paradigm change by encouraging and directing these large private investments in technological R\&D.

The Japanese government has instituted a "research association scheme," which can cause the creation of new companies and which improves existing ones. In this R\&D program, the government works with competing companies to develop concerted research efforts. The government also provides funds and tax benefits. The competing companies share costs and researchers; thay avoid conflicts of interest by solving problems that they share but are not

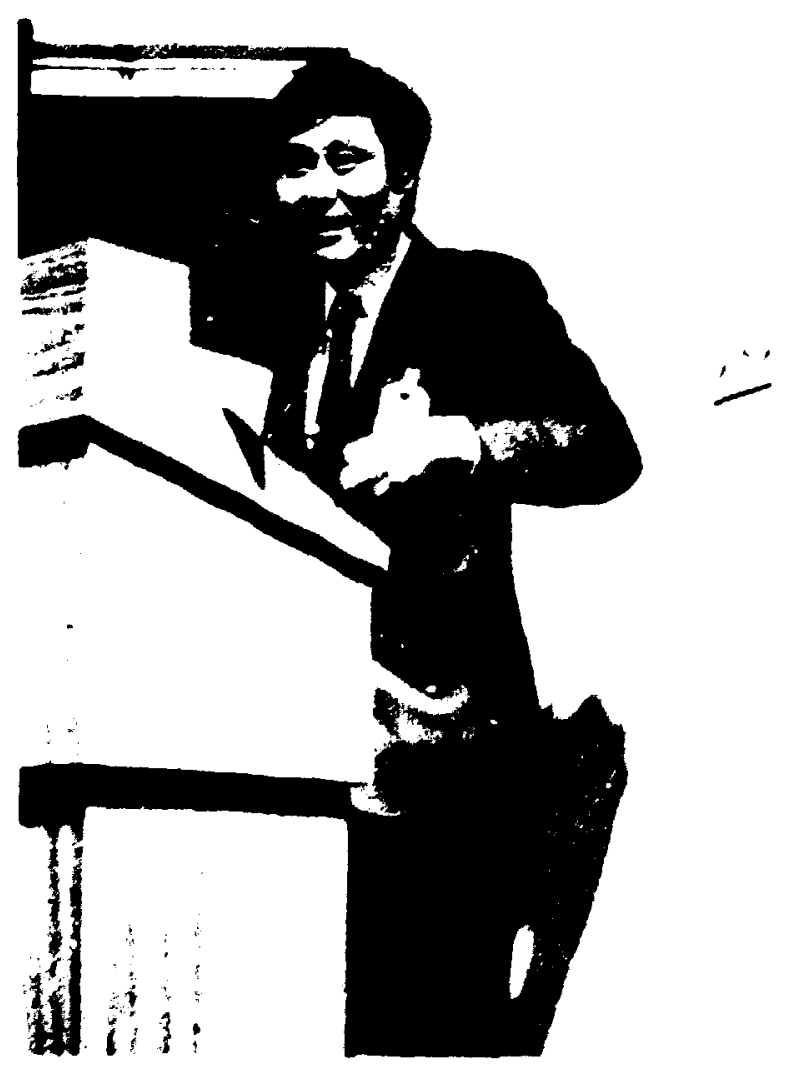

Dr. Fumio Kodama, profeceor of innovation policy at Eaitama Univereity and director of Japan's National Inatitute of Science and Technology Policy. "The corporetion could be sald to be shifting from being a place for production to baing a place for thinking: thinking for survival, thinking for the future." 
directly related to their product line. Existing vendors and support companies utirefit from this research, and now companies may be formed to satisfy the new materials needs brought about by this research. Participating companies commonly form parallel, in-house research teams that work conciurrently with this research effort. Investment in a parallel team is considered venture capital for the individual companies.

Kodama used the Very Large Scale Integration Project to illustrate a successful example of this scheme. With government support, competing producers of computer chips collaburated to improve the production of silicon crystals. The companies avoided conflicts of interest by solving problems that concentrated on making silicon rather than making chips. In this way, they created new opportunities for vendors of silicon crystals, optical fiber, and manufacturing support equipment witnout jeopardizing their own product line. 


\section{The Role of Science in Manufacturing}

Speaking from the point of view of American industry. Gomory discussed the role of science in product development. He offered specifir. reasons for close collaboration between private industry and the national laboratories. He defined two distinct methods of product development, which he demonstrated with two models: the ladder and the cycle.

The ladder model of product development describes the comparatively rare occasion when novel scientific discoveries make possible novel technical applications. Gomory offered the examples of the new developments in nuclear physics that led to the building of the atomic bomb and the new developments in solid-state physics that enabled the development of the transistor. These new discoveries descended the ladder from the realm of science into the realm of manufacturing and development. Prevalent in universities and government research laboratories, this ladder mechanism is dominated by scientis:s, whose expertise governs the work of the engineers.

Much more common is the product-development cycle, which takes place within individual private companies. Once a product is established, it undergoes recurrent refinement: design r!lange to prototype to manufacture. This cyclic process is dominated by engineers within the company. It is a closed system, constrained by manufacturing deadlines and by the tooling capabilities of the manufacturer. This cycle is also fueled by the market; a company with a faster cycle time has the appearance of being an industry leader

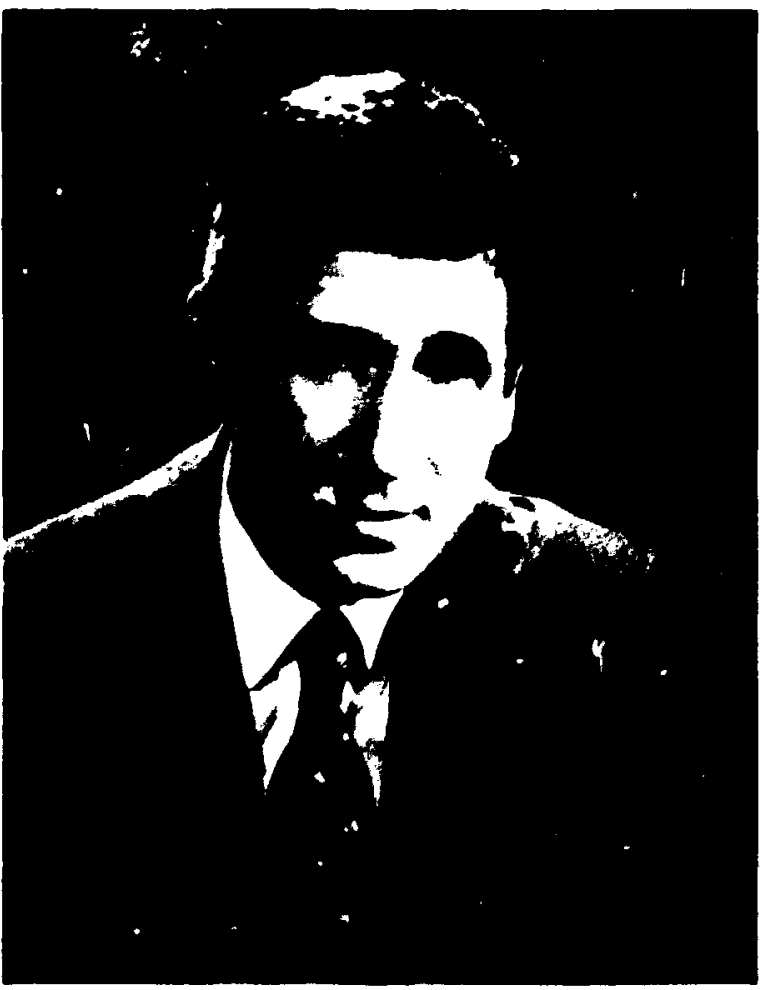

Dr. Ralph E. Gomory, senior vice president for sciance and technology, IBM Corporation: "It is extremely important that . . . the engineers in the manufacturing and dovelopment cycle, go out arud look for now ideas and pull in those that fit." 
Because this refinement cycle is a closed system, scientists conducting basic research without knowledge of the constraints involved have bitte chance of having their new ideas applied to converitional manufactured goods. An engineer with hands-on experience with a prouict can apply a novel ides at an opportune moment during the cycle; however, it is nearty impossible for someone on the outside to impose a new idea, no matter how good that ides appears to be. For that reason. Gomory said that "it is extremely important that ... the sngineers in the manufacturing and development cycle go out and iook for neiv ideas and pull in thoss that fit." 
Energy Systems has granted a license to Wyle Laboratories of El Segundo, California, to market a device that diagnoses motor-driven systems by analvzing current flow through the systenis efectric motor. The motor current signature analysis (MCSA) device was developed by David M. Eissenberg and Howard D. Haynes of ORNL's Engineering Technology Division. The work was part of the Nuclear Regulatory Commission Plant Aging Research Program to assess the aging of motor-operated valves used in nuclear power plant safety systems.

This new diagnostic tool is suitable for widespread application as a means for cost-effective condition monitoring of many types of electric-motor-driven mechanical equipment. Advantages of MCSA inchude the use of noninvasive jamp-on current probes as sensors, which can be located anywhere along the power line to the motor, insluding at imote motor-control centers. In addition, unlike accelerometers, which can sense in one plane only, the MCSA can detect and monitor all mechanical loads.

Ask for Bulletin Numbor 608.

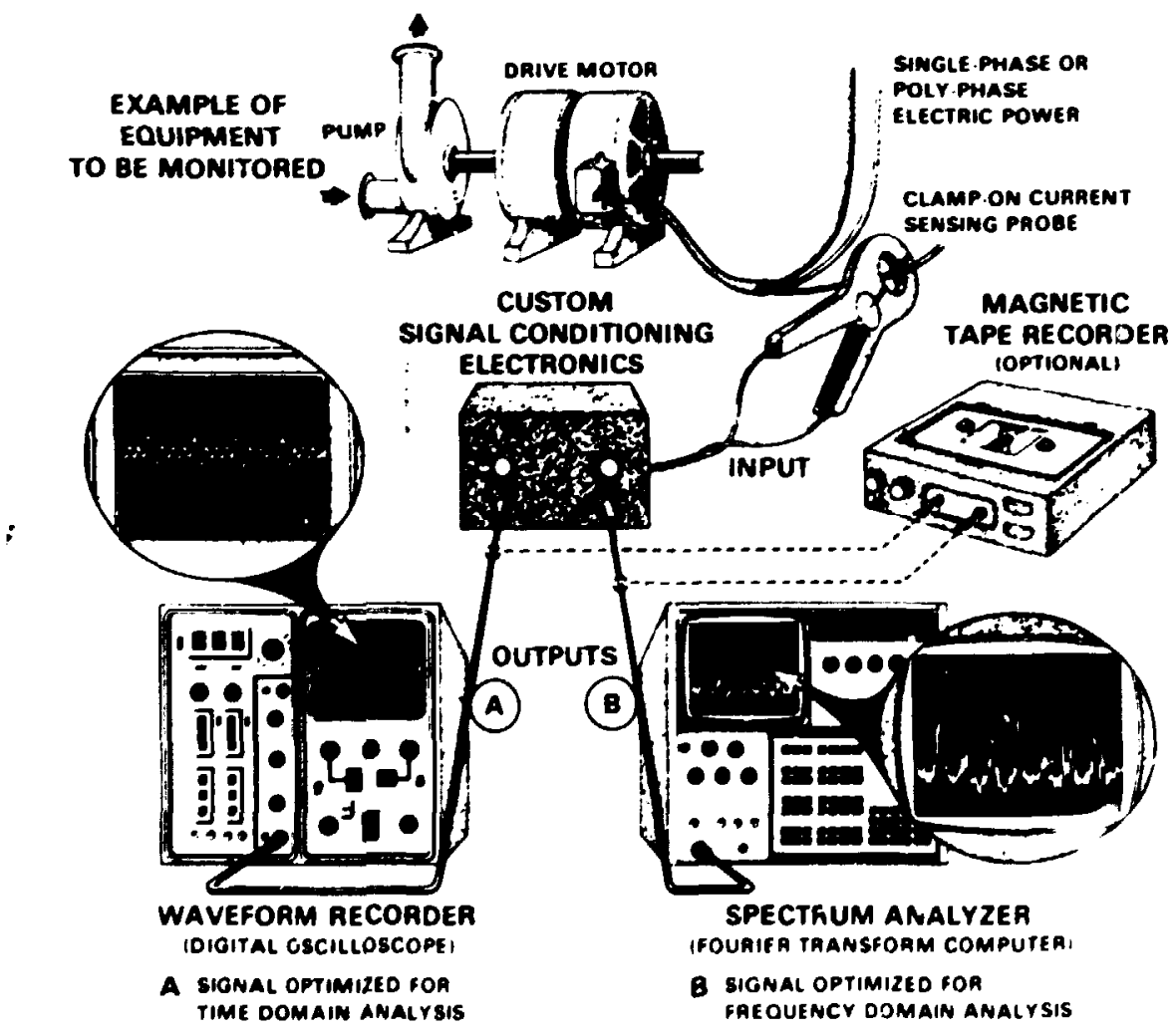

MC8A applied to e centrifugal pump. The output signals obtained in A and B are analyzed to detormine load changes within the pump and motor thet correspond to degradotion and sorvico wear and thus provide evidence of incipient failure. 


\section{Roof Research Center Dedicated}

The Roof Research Center, operated by ORNL's Energy Division, was officially dedicated during a public ceremony on September 14 . Designated as a national user facility, this $\$ \mathbf{2 . 8 - m i l l i o n}$ experimental station is used for research to iprove th: thermal efficiency of all typos of roof systems white maintaining durability and long service. all at competitive prices. The centerpiece of the Roof Research Center is the Large-Scale Climate Sirnulator, which consists of two chambers. One chamber simulates outdoor weather conditions; ihe other, indoor conditions. A second facility. the Roof Thermal Research apparatus, is used primarily to monitor the long-term field thermal performance of different types of roof systems.

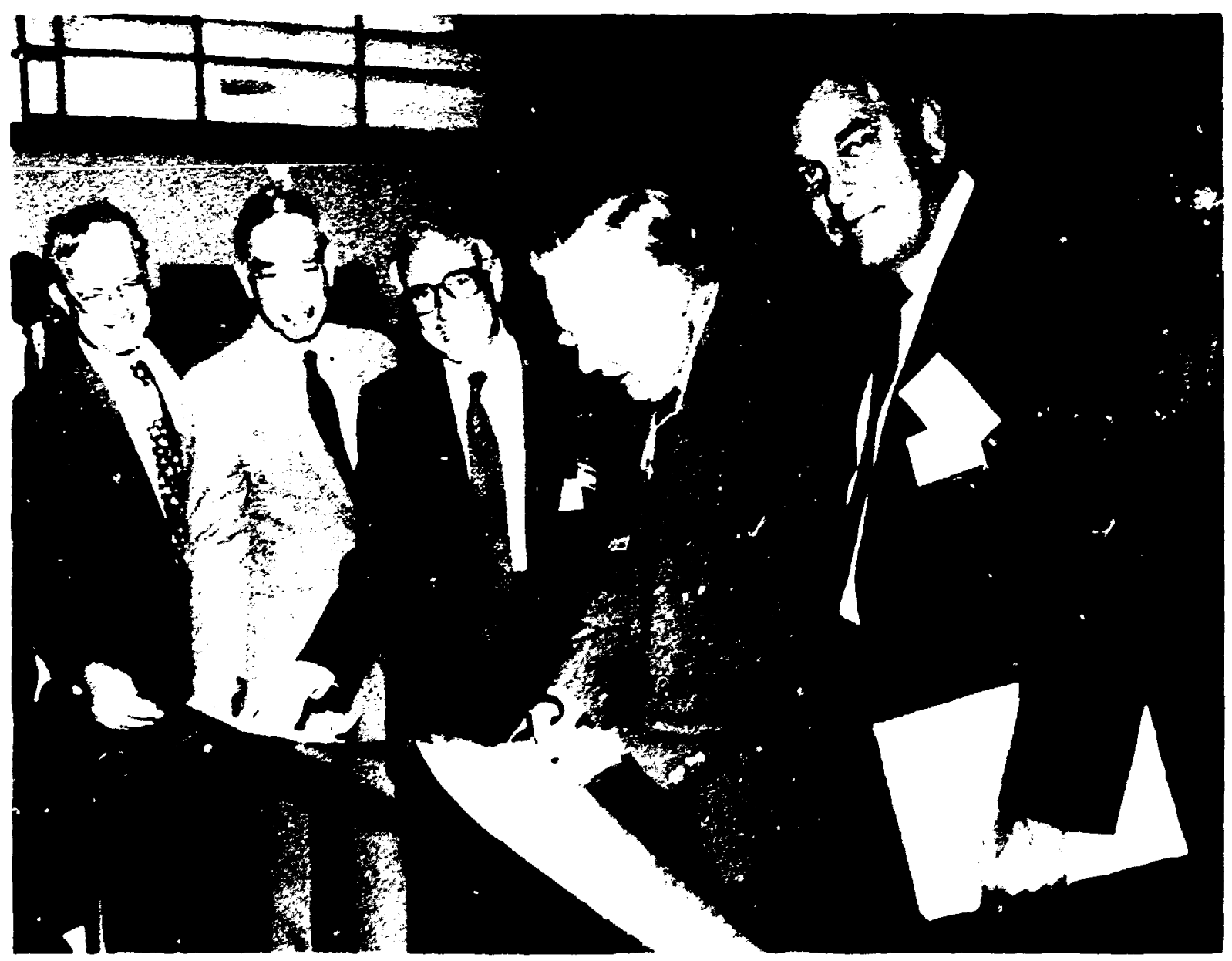

John Barg. DOE principal deputy aseistant secrotary for Consorvation and Ronewable Enorgy. cuts the ribbon (made of roofing folt) at the dedication of the ORNL Roof Research Conter. Also pictured are (loft to right) George Courville, program manager, Building Thermal Envelope 8yatems and Matorials; Murrey Rosenthal, OANL aseociate director for Advenced Enorgy Syetems; Roger Bangston, vice president and general manager of Mnnville Corporation's Roofing Divizion; and Marlin Pottoiger, president, National Roofing Contractors Aseociation. 
Specific projects for the center can be suggested by DCE and ORNL staff and by the roofing industry. Provisions are also available for a limited amount of proprietary research for specific companies. A users' manual, A National User Facility for Thermal Performance and Durability of Roofing Systems is available to those interested in research at the Roof Research Center.

Ask for Bult:- Number 633. 


\section{Imaging Agent Licensed to Du Pont for Research Applications}

Energy Systems has granted a license to E. I. du Pont de Nemours and Company for an ORNL nuclear medicine technology that can be used to manufacture a chemical compound that may hetp doctors detect cancer in its early stages. "This is the first royalty-bearing license for a nuclear medicine tect: lology developed at ORNL," said Bill Carpenter, Energy Systems vice president for technology applications. "The ayreenvent enables Du Pont to supply the compound to research institutions across the country." Du Pont will sell the new compound through its Medical Products Department in Boston.

A group of ORNL researchers, led by Prem C. Srivastava of the Nuclear Medicine Group in the Health and Safety Pesearch Division, designed and synthesized the new chemical agent known as iodophenylmaleimide. This agent is labeied with radioactive iodine and can be attached to antibodies specific to proteins produced by cancer colls. When linked to the antibody, the ORNL compound will be attracted to tumors where specialized cameras can detect the radiation, thus helping doctors locate the tumors at an early stage in their development.

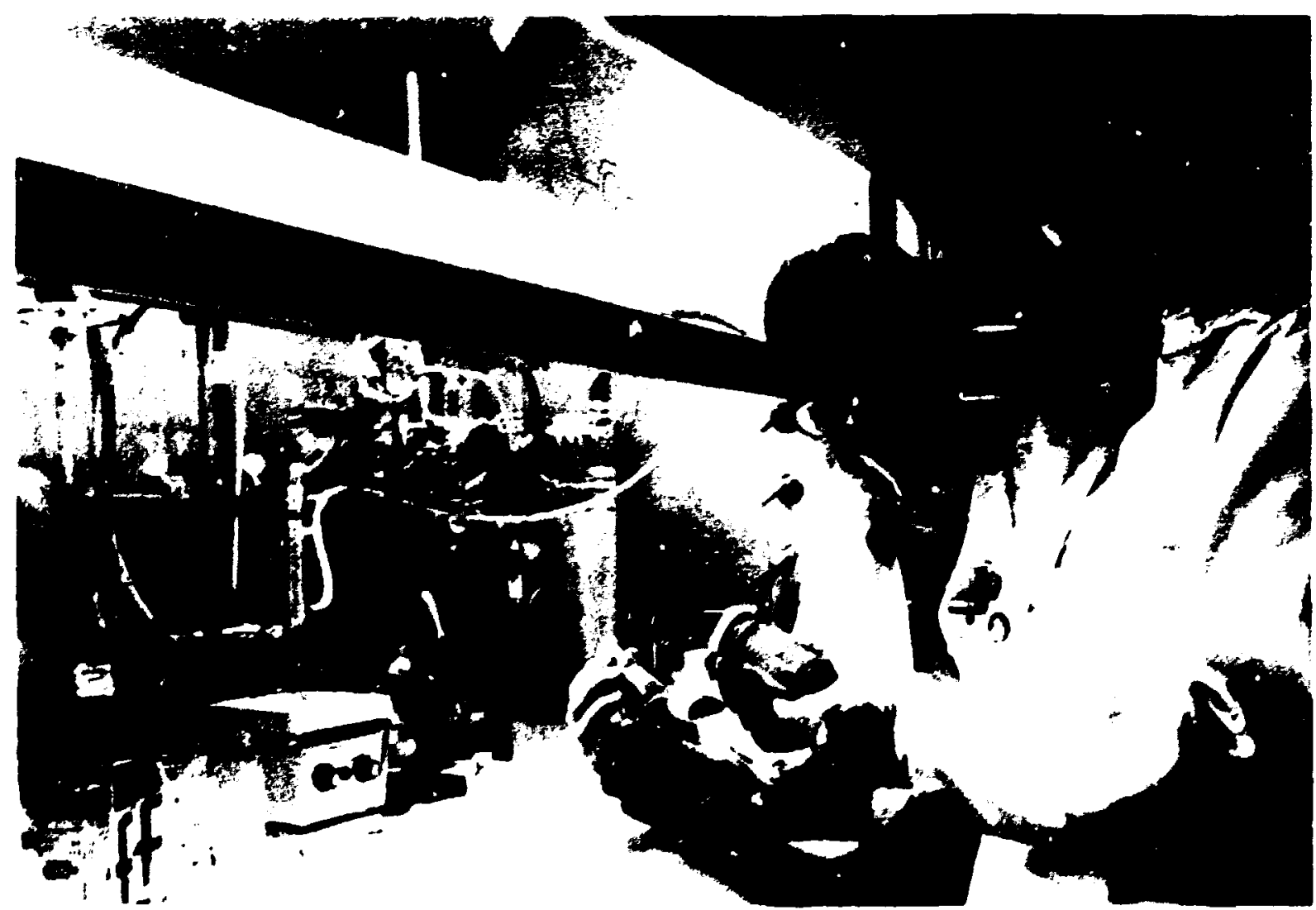

P. C. Srivesteve (right) led the team thet developed the newly liceneed iodophenylmabimide imeging egent. He is shown being seaisted by team member John Allred. 
Studies at ORNL and the University of Michigan show that the ORNL agent enables antibodies to ietain the iodine much better than agents now being used. This capability would gieatly decrease the patient's exposure to radiaticn from released iodine. In addition, iodine retention increases the half-life of the radilabeled antibody, which ensures opiimum therapeuic effect.

See Bulletin Number 683 in this issuf. 


\section{TECHNOLOGIES AVAILABLE FOR LICENSING}

The following technologies are currently available for licensing from Energy Systems:

- ZZX-4200 High-Temperature Thermal Insulation Structures (Bulletin Number 600)

- Nicke! Aluminides

(Bulletin Number 599)

-Whisker-Reinforced Ceramic Matrix Composites

(Bulletin Number 568)

- Automatic Coordinate Measuring System

(Bulletin Number 612)

- Lead-Indium Phosphate and Lead-Scandium Phosphate Glasses for Optical Components (Bulletin Number 622)

- Ultrasonic Ranging ar.d Data System

(Bulletin Number 579)

- Triple-Effect Absorption Chiller Using Two Refrigeration Circuits (Bullotin Numbar 684)

- Seven-Effect Absorption Chiller Using Three Refrigeration Circuits (Bulletin Number 685)

- Motor Current Signature Analysis Process

(Bulletin Number 608)

- Demodulation Circuit for ac Motor Current Signature Analysis (Bulletin Number 678)

- OPSNET Parallel Computer (Bulletin Number 650; 


\section{ALGORITHMS FOR EFFICIENT USE OF MULTIPROCESSOR HARDWARE}

Key words: Shared-memory multiprocessor; distributed-memory muttiprocessor; hypercube; computational algorithm; linear systems

Because of recent developments in computer hardwere, berge and powertul perallel computer architectures have become commercially avaiable. Distributed-memory muttiprocessors (such as the hitel and Nabe hypercubesl and shared-merrory multiprocessors (such as a Sequent Balance 8000) are potentially much faster than similar single processors and chesper than serial processors of similer aggregate power. The challenge for computer programmers lies in developing algorithms that maximize the efficiency of these new machines. Researchers in ORNL's Mathematical Sciences Section are developing and refining a varioty of alporithms for efficient perallel processing.

For example, algorithms and software for serial computers have akeady reached a high state of devalopment for performing matrix factorizations and using the resuting factors in the solution of systems of linoar equations, such as a system derived from the diacretization of a partial differential equation. The six ORNL reports deacribed in this bulletin present and analyze aborithms for such matrix computations on shared- and distributed-memory parallol computers. Aborithms have been daveloped for the LU factorization, where the matrix factors are a lower triangular matrix $L$ and an upper triangular matrix $U$, and for the QR factorization. where the factors are orthogonal $Q$ and upper triangular $R$.

In the ORAll report. Solvtion of Sparse Positive Definite Systerns on a Shared-Monory

Mutiprocessor, algorithms are presented for performing the Cholosky factorization (which is an $L U$ factorization with $U$ equal to the transpose of $U$ of a sparse matrix and for solving the resinting sparse triangular systems on a shared-mremory perallel computer. Numerical experimenis demonstrating the performance of these algorithms on a Sequent Balance 8000 system are documented.

QR Factorization of a Dense Matrix on 2 Shared-Memory Mutiprocessor contains a new algorittm for computing an orthogonal decomposition of a rectangular matrix on a shared-memory computer. This algorithm, which uses Givens rotations, features a low synchronization cost. Analyses and experiments performed on an eight-processor Sequent Balance 8000 show that the algorithm is effective in balancing the load and producing high efficiency (speed-up).

Truee reports containing tested factorization algorithms are also available for distributedmemory multiprocessors. Parallel Solution of Triangular Systems on Distributed-Momory Multiprocessors presents several algorithms for solving triengular systems of linear equations. Now wavefront algorithms have been dovoloped for both row-oriented and column-oriented matrix 
storage. The pertormance of new and previously proposed aborithms is analyzed theoretically and ilustrated empirically cising implementations on Amtek, Intel, and Nabe hypercubes.

LU Factorization Algorithms on Distributed Memory Mutiprocessor Architectures describes four approaches for implementing the $L U$ factorization on a hypercube. Four algorithms were analyzed to determine whether the choice of storage scheme for the coefficient matrix a pivating strategy affects the efficiency of parallet fact Jrization; the algorithms preferred for given sets of concitions were identified. Empirical results were obtained by implementing the aborithms on an intel iPSC hypercube.

OR Factorization of a Danse Matrix on a Hypercube Muttiprocessor describes a scheme that involves embedding a two-dimensional grid in a hypercube network. An algorithm for reducing a rectangular matrix to upper triangular form using orthogonal transformations on a hypercube mutiprocessor is described. Numerical experiments were performed on a 64-processor intel iPSC hypercube to verify the theoretical resutts.

The problem of load balancing on a hypercube has also been addressed. A row-oriented implementation of Gaussian elimination with partial pivoting on a local-merrory multiprocessor is described in Gaussian Elimination with Partial Pivoting and Load Balancing on a Multiprocessor. The simple, inexpensive load-balencing scheme described in this report maintains computational balance in the presence of pivoting. An analysis of the communication costs of the algorithm is developed, along with an analysis of the computation performed in each node processor. Experiments using an Intel iPSC hypercube are described to demonstrate the extent to which the analytical model predicts performance.

\section{Additional information:}

Office of Technology Applications Mertin Merietro Energy Systems, Inc. P.O. Box 2008

Odk Aidoe. TN 37831-6257

Tolephone: (6 15) 574-4192; FTS 624-4192

E. Chu and A. George, OR Factorization of a Dense Metrix

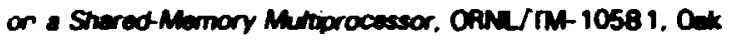
Pidpe Netionel Leboretory (October 1987 ).

E. Chu and A. Georop. OR Factorization of a Donse Metrix on a Hyperabe Mutriprocesseor. ORNe/TM-1069 1. Oak Ridge Nationd Leboratory (Februery 10. 19881.

G. A. Geist and C. H. Romins. LU Factorization Aborittions on Distributed-Momory Newtiprocaseor Archinactures. ORNL/TM-10383. Oak Ridpo Netiond Laboratory Merch 1987.

A. Georos and E. Chv, Gevesien Elimination with Pertied Pivoling and Load Bedencing on a Mutiproceseor.

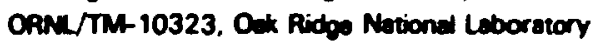
(March 1987).

A. Georpe of al., Solvtion of Spurse Pavitive Definite Systems on a Shered-Memory Mutiproceseor. ORNL/TM-10260. Oak Ridos Nationd Laboratory (Uenuery 1987).

M. T. Hoath and C. H. Romine. Paraluy Solvtion of Trianguler Systems on Distributed-Momory Mutiprocesecors. OANK/TM-10384, Ouk Ridos Mationd Laboratory (March 1987). 


\section{MEASUREMENTS AND CONTROLS}

\section{HRXRP-5 HIGH-RESOLUTION X-RAY MICROPROBE}

Key words: X-ray microprobe; elemental fhorescence; nondestructive testing

A new high-reschution $X$-ray microprobe, the HRXRP-5, has been developed at the Oak Ridge Y-12 Plant. The HRXRP-5 produces highresolution color images of the distributions of chemical elements in metals, ceramics, and composites, as well as in biological and geological materials (Fig. 1). It uses a highly collimated. intense $X$-ray beam as a fluorescence probe. $A$

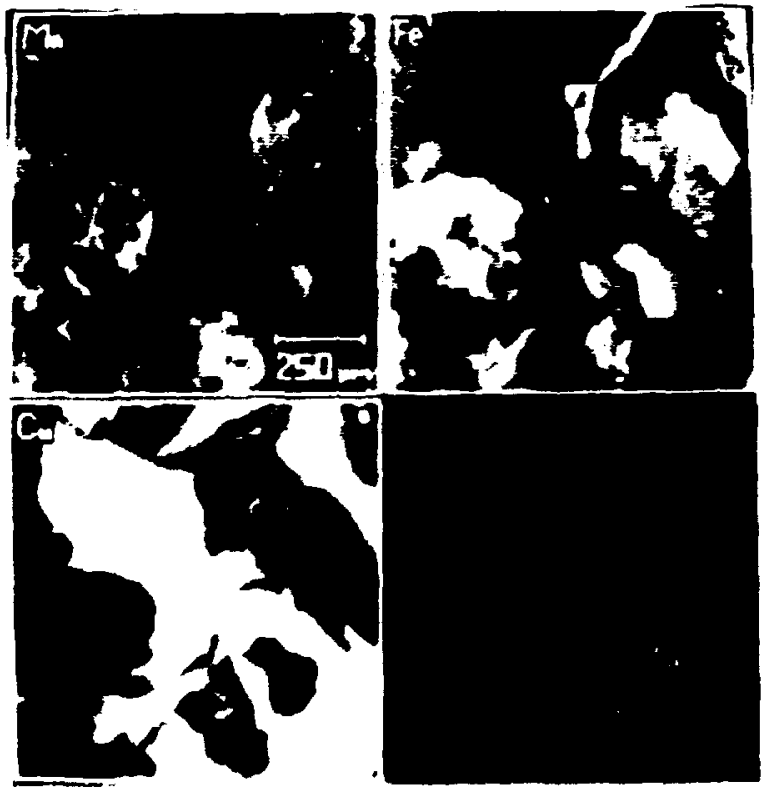

Fig. 1. Elemental dietibution in e maischite ore. These orey scale imeges show separtete slomem distributions in - higher-contreat format than the color composite (see cover). Comparieons between the two formats feciltate feature location and characterization. typical anahysis with HRXRP-5 is corried out in air with little or no sample preparation and is fast enough to maintain a high sample throughput.

During an analysis, a highly collimated $X$-ray beam impinges upon the sample surface, causing specific elementel fluorescence. The fluorescent $X$ rays are captured with a solid-state detector and then separated by energy to identify each element present in the analysis volume. This analysis is repeated up to 40,000 times per sample by translating the sample in a grid pattern normal to the incident $X$-ray beam. Elemental spatial distributions are displayed on a graphics workstation as color, grey-scale, or color topographic images.

The HRXRP-5 fils a technological gap between high-resolution electron-beam microprobes and low-resolution $X$-ray beam devices. With the $X$-ray microprobe, analyses are carried out in air. whereas electron-beam microprobes require a high vacuum. Unlike electron bearns, which are limited to the near surface, $X$ ray beams can penetrate up to $40 \mu \mathrm{m}$ beneath the surface, depending on the material analyzed. In addition. the low peak-to-background ratio inherent in $X$-ray beam instruments results in greater sensitivity than electron-beam instruments. Because electrical conductivity is not required, the specimens do not need to be coated with a thin film of conducting substance. Thus, nondestructive tests can be carried out on ceramics and biological materials in addition to metals and alloys. 
The HRXRP-5 occupies a urique position in the field of $X$-ray beam-induced $X$-ray fluorescence instrumentation because of its high resolution and speed. The unique features of the HRXRP-5 are its high-brilience, leboratory-based $X$-ray source combined with a tighty coupled collimation system consisting of extremely fine-bore glass capilary tubing. The source is a microfocus $X$-ray tube with a 10- $\mu \mathrm{m}$ focal spot operated at $22 W$ power.

The end of the capillery tube is placed only a fow milimeters from the focal spot of the $X$-ray tube by means of a unique coupling system that uses an O-ring fitting to maintain the vacuur. inside the $X$-ray tube. $X$ rays emanating from the focal spot are transmitted down the glass capillery tubing by total external reflection from the smooth capillary walls with an intensity loss proportional to length of the tubing rather than to the square of the distance, as in conventional $X$-ray collimation using metal pinholes. A spatial resolution of nearly $5 \mu \mathrm{m}$ is obtained routinely with the HRXRP-5. Typical scans resulting in 5 um spatial resolution require from a fow minutes to about $1 \mathrm{~h}$ (com;ared to the many hicis $s$ to several days required for other instruments using laboratory sources of $X$ rays).

\section{Additional information:}

Otfice of Tectnolooy Applications Matin Mrierte Enoroy Systems, inc. P.O. Bax 2008

Oak Pidps. TN 37831-6257

Telephone: (615) 574-192; FTS 624-4192

D. A. Corpenter of a., "A Scaning X-floy Microprobe with Geas Cepiliny Colimotion, pp. 391-93 in Nicrobeam Antyaio-88, ed. D. E. Nenbury, Sen Fruncieco Press. 1988. 


\section{MEASUREMENTS AND CONTROLS}

\section{FRACTURE-MECHANICS ANALYSIS ON A DISTRIBUTED-MEMORY PARALLEL PROCESSOR}

Kay words: Fracture mechanics; nuclear power reactors; computer modeling; parallel processing

For more then a decade, ORNL has conducted research in fracture mechanics as part of the Heavy Section Steel Technology (HSST) program sponsored by the Nuctear Regulatory

Commission. The HSST program is devoted to assessing and extending the margin of safety against fracture of the tick-walled steel pressure vessebs used in light-water-cooled nuchar power reactors. This program couples material and structural testing with analytical studies using finte-element fracture mechanics to determine the behavior and structural integrity of steal pressure vessels containing crack-like flows.

The fracture-mechanics approsch accepts that some flows will be present in a structure, but assumes that conditions cen be establishod to onsure that the flaws do not grow to an unacceptable size during the lifetime of the structure. Life prediction in fracture mechanics requires calculation of crack-tip stress intensity parameters to quantify both stable crack growth and the conditions for unstable fracture in complex geometries under complex loads.

Over the last decade, numerical techniques such as the finite-dement method have been established as powerful aids to fracture analysis. However, thess numerical solutions are often executed at a considerable computing cost. especially for nuclear and aerospece applications in which a high degree of accuracy is necessary. Computation research being done for the HSST program has several goals. Two goals in the area of parallel computing are mapping key finiteelement algorithrns to a parallal processor and demonstrating the possible savings in execution time when perallal processing replaces serial processing.

A parallet-processing code was developed based on a fracture-analysis system originally designed to accommodate the limitations of microcomputers. The parallel code was designed to use a large number of processors if the problem size warrants it. This program contains a virtual crack extension technique for evaluation of the crack-tip stress-intensity parameterz and deals with 2-dimensional geometries, linear elastic material behavix, and static loadings.

A parallet muliffontal solution technique, which assigns one front to each processor, was developed and tested using a hypercube parallet processing computer. For the test, a small example problem lending information to crack extension in plates (such as neutron-hardened boiler plates) exposed to thermal shocks (Fig. 1) was run. This example was implemented on five processors (four hypercube processors and one host).

The problem was partitioned into four subproblems, each of which was assigned to its own processor. Additional "super boundary 


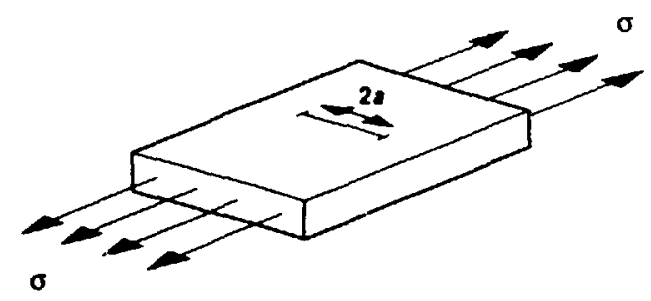

$\sigma$

(a)

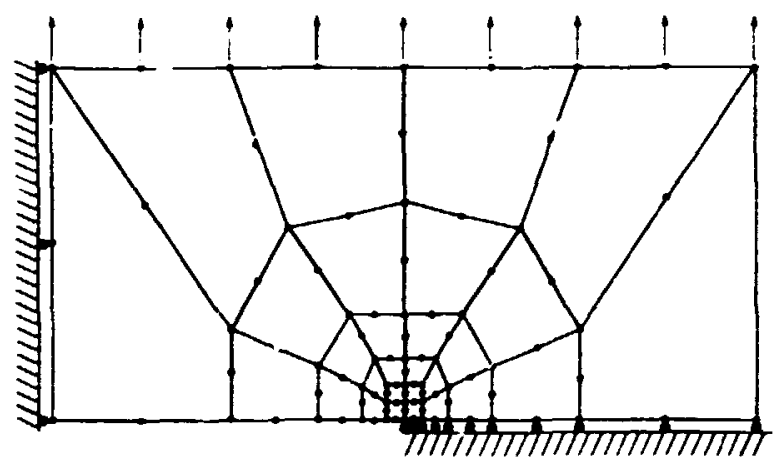

(b)

Fio. 1. (a) leon for the cimple frecture problem of a plete with a center creck of length 20 loaded mechenically to the otrees lovel $\sigma$. (b) Finito-element mech of problem in ( $b$ ) contuining 28 ebments and 101 nodes. The roller boundaries on the left and bottom sides provide symmotry. Strees is epplied as loads on top nodes. The crack is contained in the bottom-center two elements.

elements." around which communication and redundant calculations revolve, were also definusd (Fig. 2). Each processor operated on the assumption that it was solving an entire problem although only the host processor knew the complete structure of the test problem. Overall execution time for the the test problern was decrsased by more than $58 \%$ in comparison with serial processing. Even larger savings are possible when problem size and/or complexity increase. More complex problems, such as some nonlinear fracture problems, could greatly benefit from employing ideas from this method of finiteelement fracture analysis.

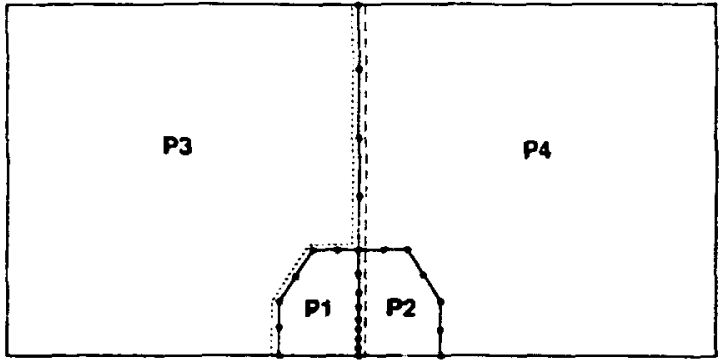

Fig. 2. Pertitioning of sample into four blocks/ eubproblems, with two super boundary elements (SaEs) dellinented by decthed lines. The dots are the nodes on the block boundaries belonging to the gate. Each block (P1-PA) is ascigned to he own hypercube procesecor.

\section{Additional information:}

Office of Toctmology Applications

Martin Mariotta Energy Systems, Inc.

P.O. Box 2008

Oak Ridge, TN 37831-6257

Telephone: (615) 574-4192; FTS 624-4192

J. A. Cinerd and G. A. Goist, Implementing Fracture Anetyais on a Distribured-Manory Parallel Procesesor. ORNL/TM-10367. Oak Ridoe Notionel Leboratory (March 1987). 


\section{MEASUREMENTS AND CONTROLS}

\section{LINEAR HARMONIC ANALYSIS OF FREE-PISTON STIRLING ENGINES}

Koy words: Freo-piston Stirling engines: modeling theory; thermodynamics; dynamics

Researchers in ORNL's Engineering Technology Division have developed the linear harmonic analysis (LHA) method, which provides insights into both the thermodynamics and dynamics of freo-piston Stirling engines (FPSEs). Unlike a numerical approach, LHA provides a semiclosedform solution that offers additional insights into the underlying physical processes of FPSEs and provides a solid basis for further theoretical development.

This research was based on the Sunpower RE-1000, a well-tested, well-documented commercial reference engine (Fig. 1). The RE- 1000 engine contains a single power piston and a displacer sprung to the engine housing. For the current version of LHA, the working space of the engine is divided into three control volumes, and motion of the engine housing is neglected. However, LHA is not limited to such a simple representation; more control volumes or dynamic equations could be added if necessary.

Cylinder heat transfer, pressure drop, and seal leakage losses are all included in the current version of LHA. These variables are included simultaneously as part of the thermodynamic/ dynamic calculations so that all of the interactions between the losses, thermal performance, and dynamic behavior are ar zounted for. Traditional solution methods have time-stepping integrations

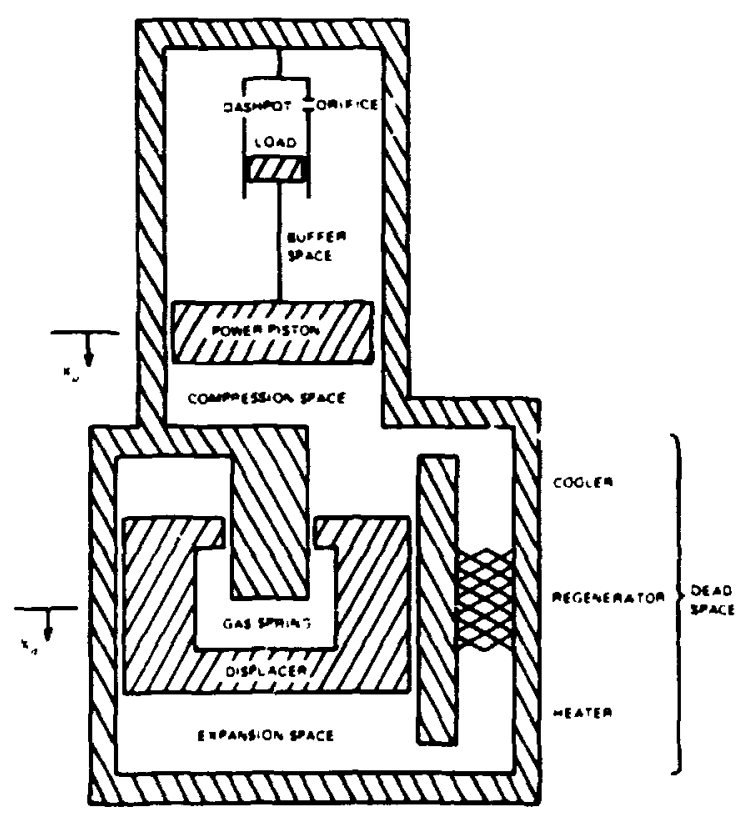

Fig. 1. Simplfied echematic of a freo-platon stirling engine.

that can be plagued by numerical instabilities and can use large amounts of computer time. The LHA solution method accounts for the important thermodynamic losses that are coupled together in FPSEs, yet it is efficient enough for optimization studies.

Execution time for LHA is about 100 times less than the time required for an equivalent numerical integration method. Even with its speed, LHA has sufficient mathematical accuracy for most practical Stirling engine applications. The mathematical accuracy of the LHA assumptions was verified by independently sciving the same 
nonlinear equations using a mumerical integration method and compering the results. The differences between the LHA and numerical predictions were loss than 5\% for all important paraneters, which is about equal to or less than the uncertainty associated with typical Stirting engine experimental measurements. This combination of computational speed and mathematical accuracy makes LHA ideal for FPSE optimization programs.

LHA also has advantages over other linear closed-form solution methods that have been developed for FPSE dynamic problems. AN previousty published closed-form solutions are second-order anatyses in which the losses are treated seperately. LHA method is a third-order analysis where the losses, as well as their interactions, are included intrinsically in the FPSE dynamic solution.

\section{Additional information:}

Office of Tectunatory Applications Mertin Meriotte Enorgy Syotems, Inc. P.O. Box 2008

Oak Ridos. TN $37831-6257$

Tdimphone: (6 15) 574-4192; FTS 624-4192

N. C. J. Cren. F. P. Grifin, and C. D. Wes., Limer Harmonic Anedysis of Stirling Engine Tharr.xodmamics. ORN/CON-155, Onk Ridoe Notionel Loboratory (Auguat 1984).

N. C. J. Chen and F. P. Gritin. Lineer Hamonic Anatrais of frew-Piston Stirting Engin Themodmamics. ORN/CON-172, Onk Pidos National Lboratory Hun 1988).

N. C. J. Chen. F. P. Giffin, and C. D. Weat. Linoer Hermonic Antyrie for Stifing Machines and Sacond Lm Andysie of Four mportent Losese," pp. 1973-81 in 19th intereccioty Eneror Conversion Engisearing Conference, Vol. 3. American Nucleer Socioty. Sen Frencieco, Aup. 19-24, 1984. 


\section{SINGLE-BOARD MICROCONTROLLER SUITABLE FOR RAPID PROTOTYPING}

Koy words: Microcontroller: computerized housing design; rapid prototyping

The National Association of Home Eunders (NAHB) Smart House Project is a cooperative research and cievelopment effort involving American home builders and a number of major corporations. The purpose of the project is to incorporate current technology in the distribution and use of energy and communication services in the home. ORNL is contributing to the Smart House Project by providing technical advice and consulting services to NAHB in the areas of overall evaluation and design, project management, and development of facilities for use in design evaluation and system integration.

Certain parts of the designs now used for home electrical and gas-distribution systems are as much as 100 years old. In spite of the radical change in energy-use patterns (from primarily lighting to primarily heating and cooling use), the basic energy-distribution and control systems used in homes have not changed in several decades. As a result, the needs of modern homes are not being met. The Smart House Project will provide designs for intelligent control and coordination services among appliances and the devices used to control their operation.

The Smart House design must meet rigid requirements for reliability, installability, and maintainability. This design will also establish a new standard of safety for power distribution in the horne. primarily by incorporating closed-bop control of electrical appliences. With this feature. branch circuits are do-energized except when power is necessary to operate appliances. To initiate the flow of power, the device controling an appliance (such as the switch on a vacuum cleaner) must send an abetronic message to the control for the circuit laading to the appliance. After the circuit is powered, the control for the circuit requires a continuing "nominal operation" signal from the appliance to maintain the supply of power.

Researchers in ORNL's Energy Division evahuated a commercially available, singlo-board microcontroller for use in developing and testing Smart House products (Fig. 1). Two ORNL reports, Evaluation of a Singlo-Baard Microcontroller Suitable for Rapid Prototyping, and 1)ptimizing the Zilog 28 FOATH Microcontrollor for Rapid Prototyping, concern criteria ORNL has developed for evaluating microcontrollers intended for use in rapid prototyping, the adaptation of a commercially available microcontroller to meet these requirements, and a summary evaluation of both the prototyping requirements and the performance of the candidate microcontroller.

Based on experience in laboratory development and testing for DOE conservation programs.

ORNL presented requirements that should be met by a microcontroller suitable for rapid prototyping. A cominercially available, FORTHbased microcontroller then was evaluated against 


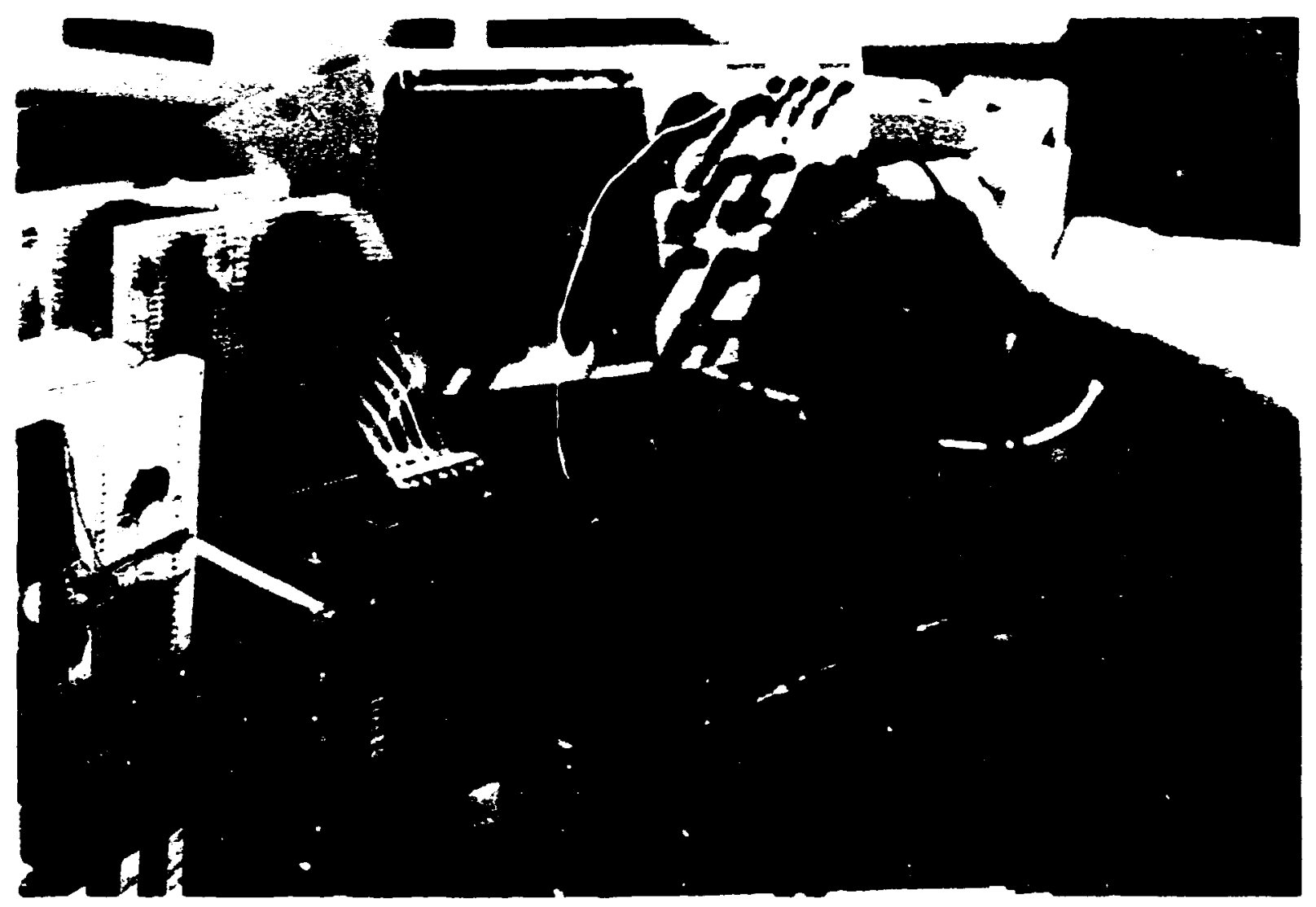

Fig. 1. Single-board microcontroller for wa in developing and tenting smart Howes producte.

these requirements. The study showed that a full-screen editor can be developed for the tested single-board microcontroller in about $40 \mathrm{~h}$.

Execution speed of a FORTH control program can range from 12 times slower to 3 times faster than IBM AT FORTH, depending on the degree of optimization of the microcontroller FORTH program. The report shows how 28 FORTHprovided system primitives can be redefined to achieve fast execution speed. Also, ORNL devised s sirrifito modification of Z8 FORTH to support multitasking. The microcontroller that was evaluated generally met rapid-prototyping requirements. The test resulted in concern about the readability of FORTH control programs, the execution speed of nonoptimized FORTH, ard the need to augment the basic complement of FORTH words provided with the microcomputer.

\section{Additional information:}

\section{Office of Technology Applications}

Mertin Mariette Eneroy Srstems, inc.

P.O. Box 2008

Oak Ridoe. TN 37831-6257

Telephon: (615) 574-4192: FTS 624-4192

R. Edwerds, Evatuotion of a Singla-Bowerd Microcontrallor Surtsble for Repid Protoryping, OANL/TM-10361, Oak Ridoe National Labochatory (February 1987).

R. Edwerds Jotimuzing the Zikg Z8 FOATH Microcontrolier for Rapud Protorypung. ORNL/TM-10463. Oak Ridoe National Loboratory (September 1987). 


\section{DEMODULATION CIRCUIT FOR AC MOTOR CURRENT SIGNATURE ANALYSIS}

Key words: Nondestructive testing; ac electric motors; electrically driven equipment; spectral analysis

\section{Motor current signature analysis (MCSA)} diagnoses mechanical problems in equipment driven by electric motors by capturing. processing, and analyzing the electrical signals generated by the motor. This technology. developed at ORNL, is currently avaibale for icensing from Energy Systems. In applying MCSA to ac-motor-driven equipment, one of the issues faced was how to deal with the $60-H z$ line frequency and its harmonics.

Because of their magnitudes, the $60-\mathrm{Hz}$ frequency and its harmonics dominate the frequency spectrum of any signal detected in the power line feeding the electric motor. In the original development of MCSA, this problem was solved by effectively demodulating the desired signel from the 60-Hz carrier by means of an rms-to-dc converter. However, because of the characteristics of this detection device, it also actod as a low-pass fiter, partially suppressing the desired frequencies near and above $60 \mathrm{~Hz}$.

An improvement to the existing demodulation technique. which provides a higher measurement resolution and sensitivity. has been developed for application to MCSA. This techrique uses two welk-known detection methods: amplitude and phase demodulation. The application of these methods to MCSA is shown in Fig. 1.

It has been found that periodic, load-induced variations in motor current signals simultaneously

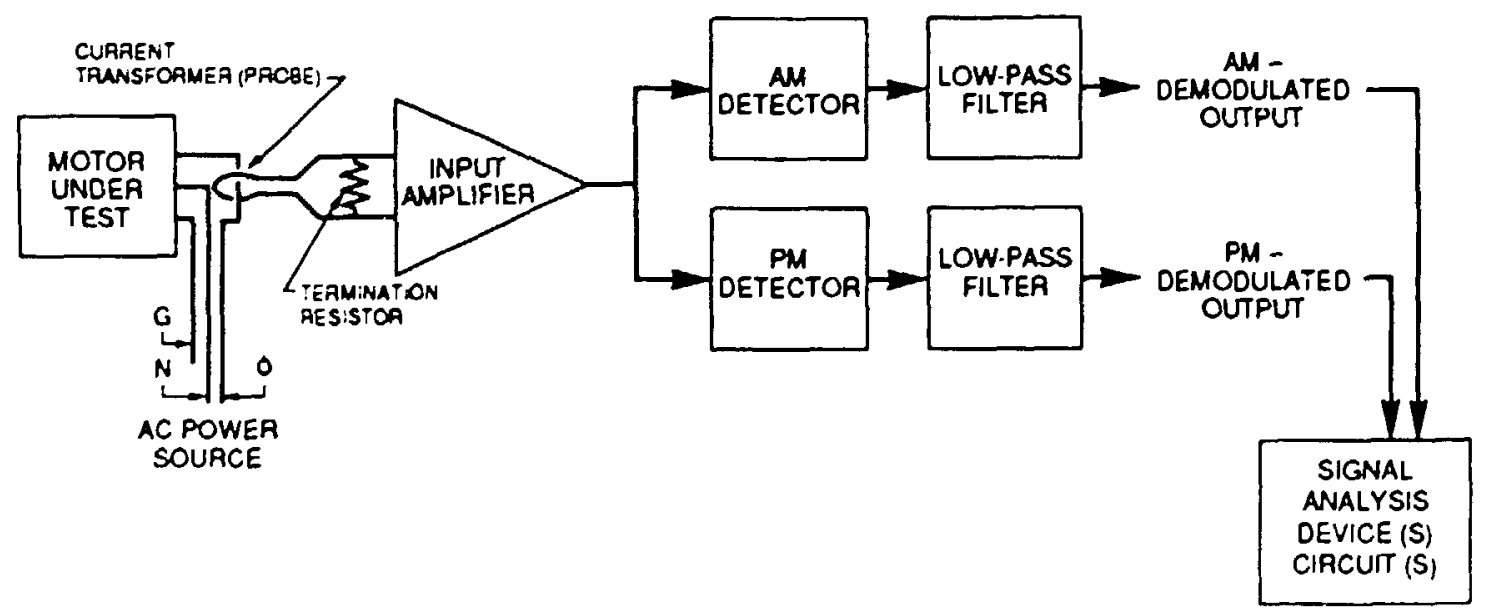

Fig. 1. Block diegrem of the demodulation clicun for ac motor current signature analyais. 
produce amplitude-modulation (AM) and phasemodulation (PM) effects. However. certain types of frequency sources tend to produce proportionately more of one type of modulation than the other. For that reason, both $A M$ and PM detectors are provided in this design for analysis and comparison. The AM demodulator can be provided in the form of integrated electronic chips or discrete element circuits. It may be one of several types, but preferably it should be a synchronous or "product" detector. The PM demodulator can be a quadrature. discriminator, FM feedback, phase-locked loop. or putse-counting/pulse-width type. In addition. the use of phase demodulation can provide an instantaneous power-factor measurement for the motor if the PM detector is referenced to the applied ac line voltage rather than to the current.

This demodulation system can be implemented with standard electronic components and added onto the other spectral analysis equipment needed to implement MCSA. Although the circuit and MCSA were developed initially for monitoring motor-operated valves and compressors in gaseous diffusion urarium-enrichment plants, the techniques may be applied as wey in industry for monitoring, diagnostics, trend analysis, and preventive maintenance programs for a wide variety of electrically powered devices.

\section{Additional information:}

Office of Tectnoloov Applications Murtin Mariotu Energy Systems, inc. P.O. Box 2008

Onk Pidpo. TN 37831-6257

Telephone: (615) 574-4192: FTS 624-4192

"Motor Curreme Signoture Anelvis Procass." Bulotin No.

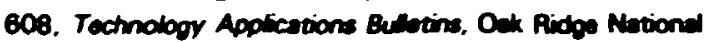
Leboratory Winter 1988). 


\section{MEASUREMENTS AND CONTROLS}

\section{TEST SYSTEM FOR EROSION-CORROSION STUDIES}

Key words: Coal conversion systems; erosion; erosion-corrosion testing; material degradation; scanning electron microscope

The combination of erosion and corrosion can cause considerable material degradation in systems such as gas turbines and coal conversion systems. For that reason, many researchers have studied these problems. Conventionally. this research has been carried out in two ways.

One test is performed with a gas gun, which directs a gas stream loaded with solids onto a target. The test particles are about the size of the erosive particles in systems of interest. However, because many grams and even hundreds of grams of particles strike the surface, onhy cumulative effects are measured; little or nothing is learned about the response of the target material to individual impacts. Another technique, in which single particles are used to investigate the basic deformation response of the target, employs particles considerably larger than those found in the systems of interest.

Consequently, it is not clear that the material behavior observed in the experiments is characteristic of that under impacts by much smaller particles.

Researchers in ORNL's Metals and Ceramics Division have constructed a system that permits studies of the impact effects of single particles of the size found in coal conversion systems. Furthermore, the test samples can be examined at temperature and under corrosive conditions with a scanning electron microscope. Erosion and corrosion studies have been performed separatehy with this device, and eventually these tests will be performed simultaneousty.

The experimental system combines a commercially available scanning electron microscope (SEM) with a gas-operated gun (Fig. 1) that shoots single particles at a specimen at high velocity and a hot stage that heats both the specimen and the corrosive test gas and directs the gas onto the specimen. The specimen holder and hot stage can be rotated about the stationary gun so that the angle of impact can be varied from 10 to $90^{\circ}$ (perpendicular to the flight pith of the projectile). To rapidly remove both the propellant gas and the corrosive test gas, a turbomolecular pump supplements the SEM's standard pumping system. A custom-designed photoelectric velocity measurement system, built into the barrel of the gun, measures the velocity of the projectile. The velocity measurements can be used to relate momentum or kinetic energy values to the damage caused by the projectile striking its target.

Two commercially available measuring devices, separate from the test assembly, are used to evaluate test saniples. A profilometer is used to make two-dimensional scans of the surfaces resulting from impacts or corrosion (Fig. 2). An ultralow-load microindentation apparatus measures the hardness in and around the impact craters. For example, indentation tests of craters 


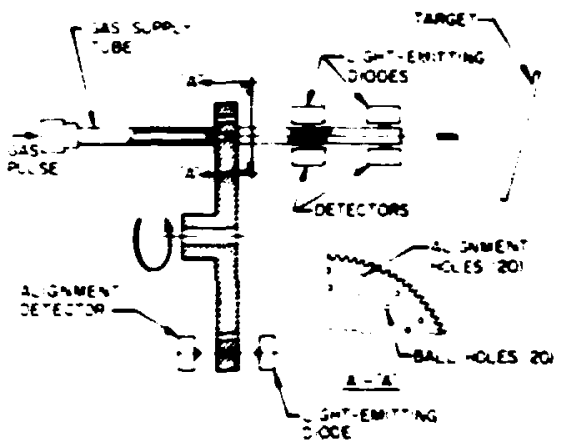

Fip. 1. Schamatic drewing of the currenth uned crosive-partich oun (not to cocel). The gen is fed by a coar-driven, 20-ehot rotery magaxino. Fech chember containing a prejectlb ball is cecompenied by en

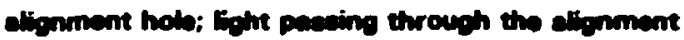
hole from a bint-enitting dods to a detector indicates thot a projectils is correcthy pochtioned to fire.

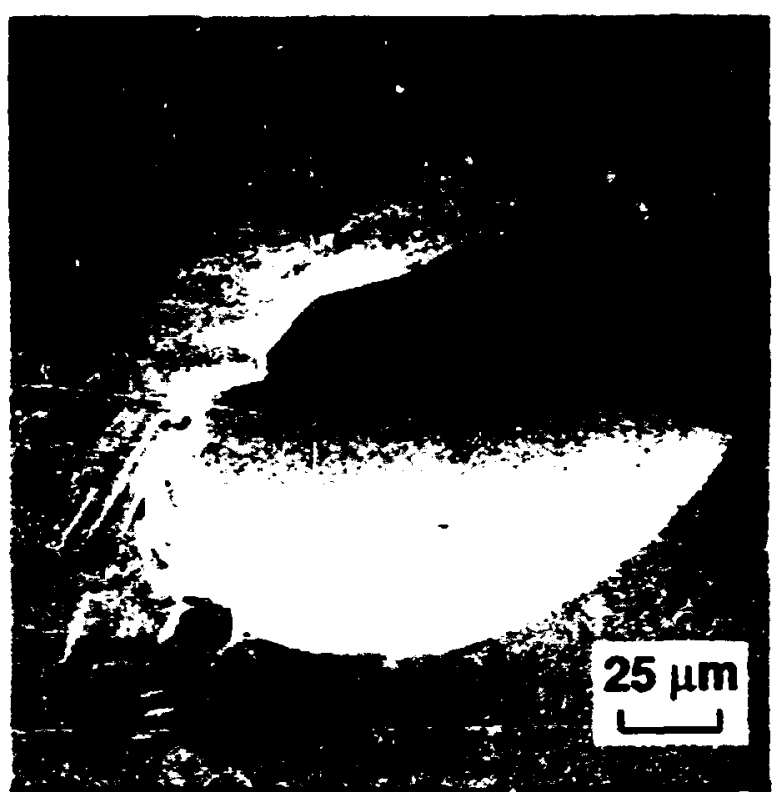

())

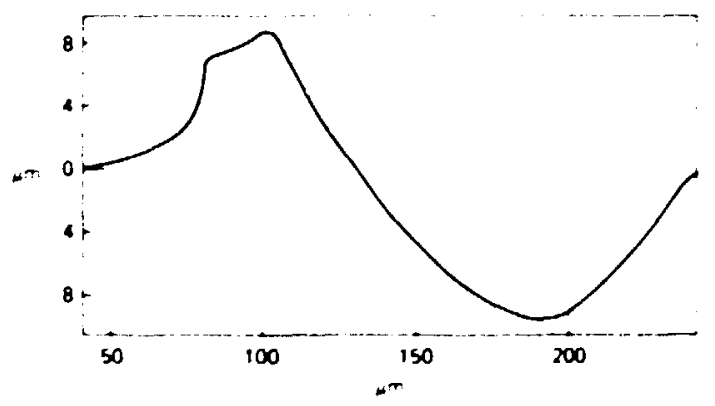

(b)

in a nickel-based alloy showed that the mittom of a crater was generally harder than the surrounding unaffected surface. In addition, an imago-entancement systern was added to the imaging electronics; this addition onables creation of a permanent digital record of images and produces images with greatly reduced noise levels.

\section{Additional information:}

Office of Technology Applications

Mertin Meriotts Energy Systems, inc.

P.O. Box 2008

Oak Ridop, TN 37831-6257

Telephono: (615) 574-4192: FTS 624-4192

J. R. Keiser. Dasign. Construction, and hitid Resutts for on Eravion-Corrasion Test Systom, ORNL/TM-10049, Odk Ridoe National Leoratory (May 1986).

Fir. 2. (a) gex imace of en wosion ireter formed by the inpact of a tungetten carbids bell imto a terest eample and (b) a two-dimentional profilometer trece of the same crater. 


\section{MEASUREMENTS AND CONTROLS}

\section{AN AUTOMATED HOT-CELL TITRATION SYSTEM}

Key words: Titration system; hot cell; nuctear fuel reprocessing

Operation of a nuctear-fuet-reprocessing plant requires an anabytical support laboratory capable of meeting process-control, product-quality, and nuclear-safeguard requirements. Because of the radioactivity accompanying many of the samples. the anahtical instruments must be selected. modified, or specifically developed for use in hot cells. Titrimetric procedures have been used successtully in hot cells and are generally immune to radiation-induced bias. The principal disadvantage of titration, which has led to the development of automated titration systems, is that it is gonerally a time- and manpowerintensive procedure.

An automated titration system has been developed in ORNL's Analytical Chemistry Division specifically for operation in a hot-cell environment (Fig. 1). This system is composed of an in-cell titrant delivery unit, in-cell electronics systerns, computer interfaces, a microcomputer, and software. The titrant delivery unit inside the hot cell is linked to the microcomputer in the operator area of the laboratory by means of a signal-distribution box.

The operating principle of the titrant delivery unit is the piston displacement of liquid. The delivery drive consists of a stepping motor that turns a precision-ground lead screw. Attached to the motion-converston nut is a permanent magnet

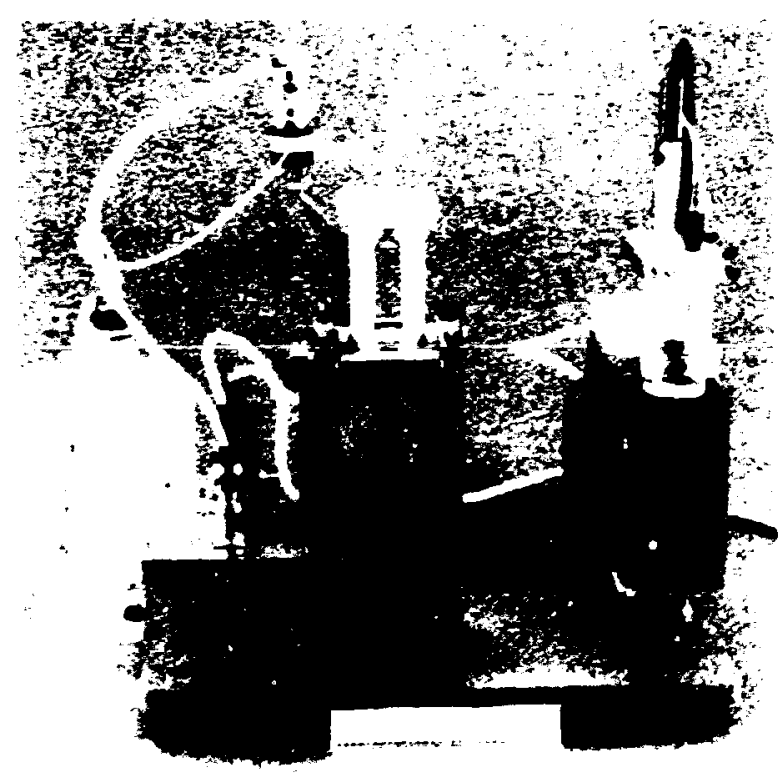

Fio. 1. W-cell spetem of the Oake remote theter.

that actuates Hall-effect proximity switches to stop the stepping motor at the tull and empty positions of the buret. The end of the piston push rod connects to the piston with the coupling system shown in Fig. 2. The orientation of the piston push rod is fixed; the piston is free to rotate. When the push rod is positioned at the buret change position, this coupling system allows the buret to be cemoved and atteched by sliding it horizontally. The buret is positioned on the delivery unit housing by a spring-loaded locating pin with a hemispherical head and is clamped securely to the delivery unit housing. A 


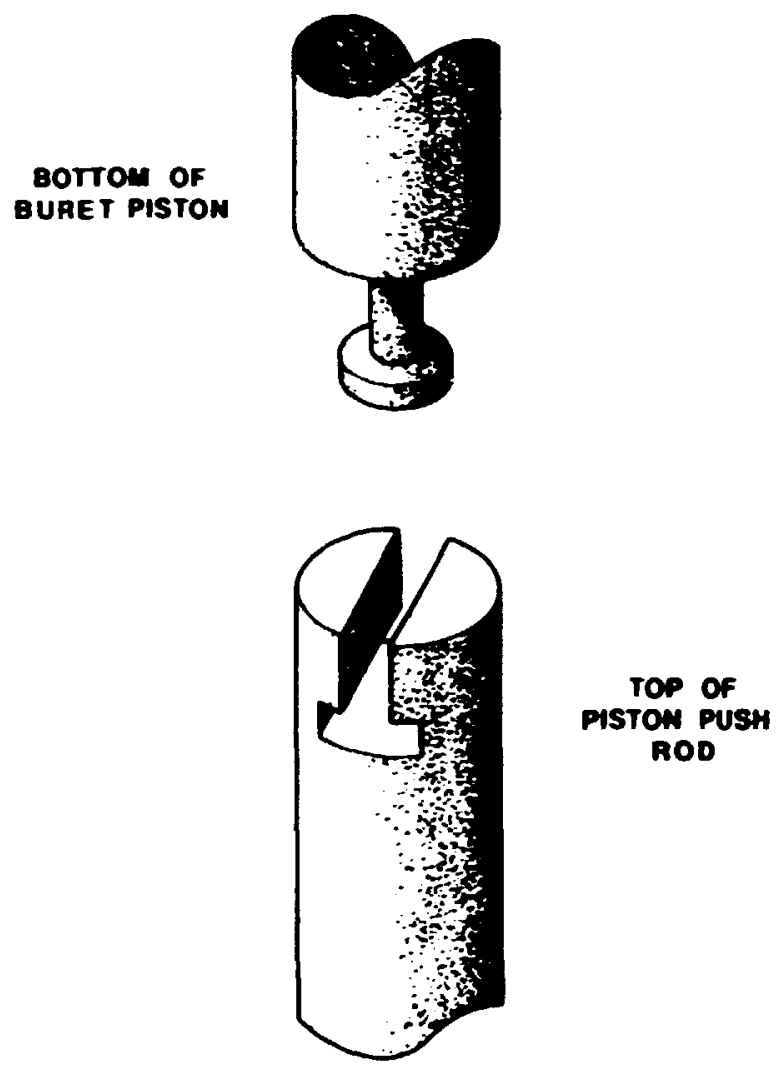

Fig. 2. Puah rod-to-piaton coupling for thtrame delivery unit.

three-way solenoid valve mounted on the buret housing is used to control the direction of fluid flow during all movements of the buret piston.

Interchangeable burets having barrels fabricated from precision-bore Pyrex tubing are available with capacities of 5,10 , and $25 \mathrm{~mL}$. The means of the absolute error in delivered volume for these burets are $0.9,1.1$, and $1.8 \mu \mathrm{L}$, respectively.
An elevator module is used to position the titration vessel under the electrades and titrant delivery :ubes. It is powered by a reversible ac motor; limit-of-travel signals are generated by Hall-effect proximity sensors, which are actuated by a permanent magnet attached to the rear of the elevator table.

Data indicate that the titrant delivery unit performs its task with tigh accuracy and precision. The titration system has been used successfully for potentiometric titrations for several years in support of nuclear-fuet reprocessing R\&D activities. Evaluation studies have shown that this system's accuracy and precision are not limited by titrator performance factors but by sample preparation procedures. the equitibrium constant of the titration reaction. and statistical uncertainities associated with the standard titrant.

This system is atso capable of performing amperometric titrations. Changing between the potentiometric and amperometric modes of operation involves changing the in-cell transducers, the in-cell eloctronics, and the titrator control program.

\section{Additional information:}

Office of Technology Applicatione Mertin Meriatts Energy Systems, Inc. P.O. Box 2008

Oak Ridge. TN $37831-6257$

Telephone: (6 15) 574-1192; FTS 624-4192

L. N. Klen. A Hor-Cell Titration System, OANU/TM-10780. Oak Pidoo Notional Leboratory (Juty 1988). 


\section{NEW APPLICATIONS OF SILICON MICROMACHINING}

Kor words: Miniature sensing devices; alpha detector: small-angle $X$-ray scattering

The use of photolithography and anisotropic etching of silicon waters to make strong, thin membranes has reated a large family of miniature sensing devices such as pressure transducers and accelerometers. Engineers at OANL have fabricated thin windows by anisotropic chemical etching of single-crystal silicon. These windows are mechanically strong and yet transparent to many kinds of radiation. Two applications of these windows have been developed: a rugged alpha detector and a fluid sample cell for smalt-angle $X$-ray scattering.

In conventional alpha-radiation detectors, the photomultiplier tube is shielded by a window that blocks ambient light but allows alpha particles to pass through. Aluminized Mylar, the most commonly used window material, is easily damaged by particles such as dirt and sand. Therefore, it is expensive to use atpha detectors in the field because they have very short life expectancies. Experiments have shown that etched silicon is an acceptable replacement for aluminized Mylar.

The now design (Fig. ") is substantially more resistant to environmental contamination and mechanical damage than the conventional design. This rugged alpha detector is physically compatible with existing instruments, so it can be easily retrofitted to replace the more fragile Mylar-window design. Its detection efficiency is

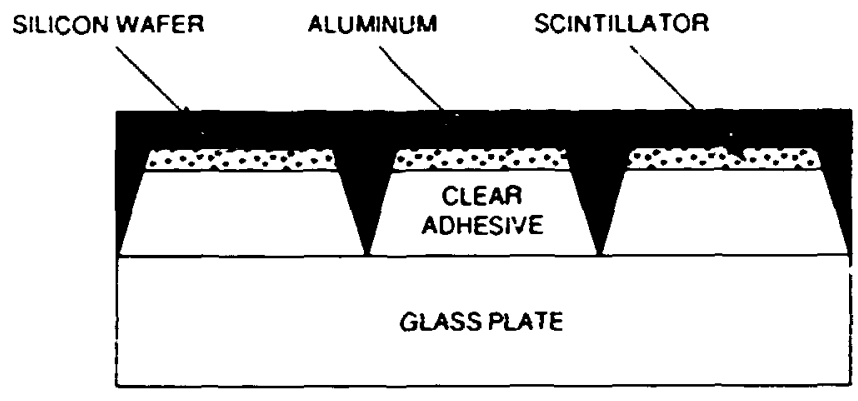

Fio. 1. Deaion for a rugeed elphe detector waing a chemically micromechined silicon wofer. Thicteneseces ore not to scals.

comparable to the older detector, yet it is highly resistant to thermal shock, abrasion, and moisture.

The second application of etched silicon wafers that was studied was their use as containers for liquid samples to be studied by the ORNL 10-m small-angle $X$-ray scattering (SAXS) camera (Fig. 2). It is difficult to examine hiquid samples in the SAXS because the $X$-ray beam line is evacuated, and the liquid must therefore be contained in a sealed capsule with thin windows.

Two common window materials are beryllium and Mylar; both materials present difficulties. Beryllium windows have unacceptably high scattering, and Mylar windows tend to balloon outward, changing the effective sample thickness. Experiments have shown that etched silicon wafers would not have either of these drawbacks: they would also be able to form strong, airtight joints by soldering to lowexpansion alloys. 


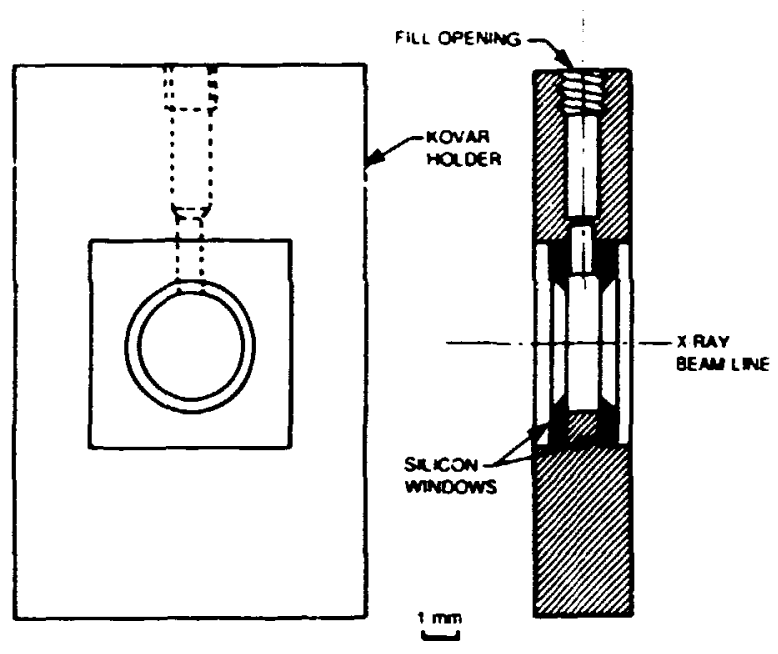

Fit. 2. Fuld sample holder for emall-engis $X$-roy ceottering. Note thet a hols could elso be drilled from

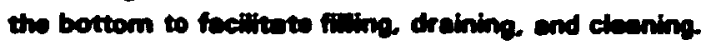

\section{Additional information:}

Office of Technology Applications

Martin Mariette Energy Sroterns, he.

P.O. Bax 2008

Oak Ridog. TN $37831-6257$

Telaphone: (6 15) 574-4192; FTS 624-4192

R. J. Leuf it a., Now Applications of Silicon Micromachining. ORN/TM- 10590. Ont Pidpo Notiond Leborntory (Wun 1988). 


\section{INSTRUMENTATION SYSTEM FOR PRECISION MEASUREMENTS OF FLOW VECTORS}

Key words: Three-dimensional fluid-flow vector; Pitot tubes; data acquisition

A new instrumentation system developed at ORNL can be used to make precision measurements of the three-dimensional fluid-flow vector in open channels, tunnels, and tubes. This system was designed originally to measure flowing water at 0 to $80^{\circ} \mathrm{C}$. but it could be adapted to measure other liquids or gases. Probes fabricated to date have a Monel tube sheath with nickel capillary-tube Pitots set in a silver solder matrix, but other construction materials could be used if required. In some applications, measurements can be made at static pressures up to several hundred pounds per square inch. The system is composed of three major components: a fixed flow probe, a sensor/electronics module (ifig. 1), and a computer-based data acquisition and analysis system.

The 0.250 -in.-diam flow probe has a $40^{\circ}$ (half angle) conical tip with seven 0.062 -in. Pitot tubes in 8 closu-packed hexagonal array. The probe has a cone of acceptance of $\pm 30^{\circ}$ in both pitch and yaw. The seven Pitot tubes extend to a seven-channel sensor/electronics module several feet away. For water speeds o: 20 to $60 \mathrm{ft} / \mathrm{s}$, differences in velocity magnituce can be resolved to $\pm 0.1 \%$ and angular differerices to $0.1^{\circ}$. Accuracy is estimated at $1 \%$ for magnitude and $1^{\circ}$ for vector angles.
The sensor/ebectronics module (1.75 in. diam and 6 in. long) is sealed and filled with oil. It contains seven solid-state pressure transducers, seven constant-current sources and analog signat-conditioning channets, and an sight-channel muiiplexer that scans the transducer array and transmits data to the date acquisition and analysis system. The eighth channel of the multiplexer transmits a signal proportional to the temperature of the pressure transducer microchip in a typical measuring channet. The frequency response of the module is restricted by $=100-\mathrm{Hz}_{2}$ low-pass firter in each analog channel to avoid signal errors caused by aliasing.

The sensor/electronics module includes a special diaphragm vatve for liquid-flow applications. This valve permits the flushing of the fluid-sensing tubes, a process which can be followed by sealing to isolate the individual sensing channels. A sealed bladder inside the module equilibrates the pressure inside the module with the static pressure of the fluid without allowing the fluid to conteminate the electronics. The comput $r$-based data acquisition and analysis system, w'ich was designed to acquire data from 30 probes and is remote from the sensor/electronics module, updates the pressure measurements from each probe at a $2-\mathrm{kHz}$ rate.

The flow-measurement system requires empirical calibration in a tow tank, water tunnel, or wind tunnel to develop a calibration matrix 

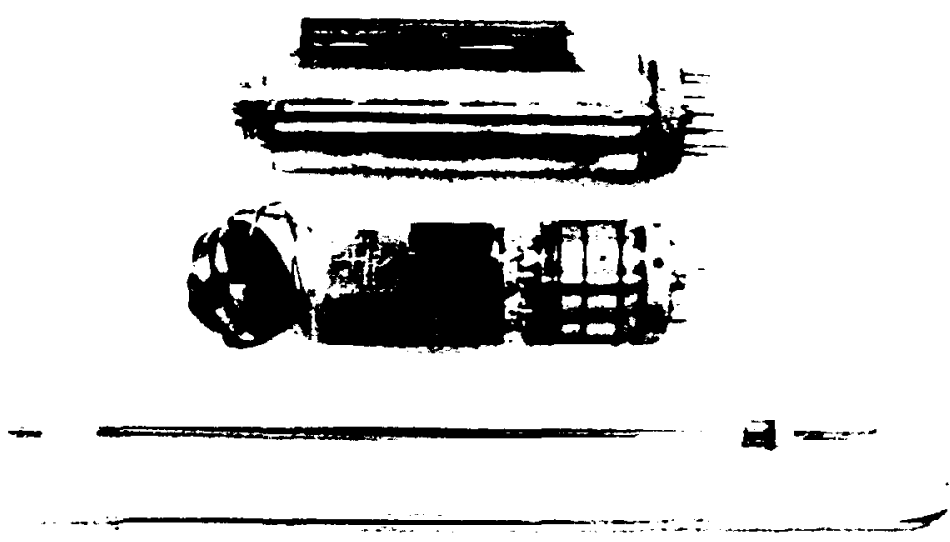

Fig. 1. Components of flow vector instrumentedion system. The sensing/electronice module (top) is connected to the fixed probe (bottom), which conteins seven Pltot tubes in a hexegonal erroy.

covering the speed, yaw, and pitch ranges of expected use. Calibration coefficients developed from these measurements allow the data acquisition and analysis system to calculate flow vectors from the relatioriships among the Pitot pressure measurements independently of any static or reference pressure measurement. However, the local pressure inside the sensor/etectronics module cannot differ from the total fluid pressure at the Pitot port by more than 25 psi without potential damage to the solidstate pressure transducers.

\section{Additional information:}

Otfice of Technology Applications Martin Moriotta Energy Systems, inc. F.O. Box 2008

Oak Ridoo, TN $37831-6257$

Telephone: (615) 574-4192; FTS 624-4192

-A Now Instrumentation Syetem for Precision Measurements of Flow Vectors, I\&C Signels, Development Bullotin No. 7. Oak Ricgo Netional Laboratory (Jenuary 12, 1988). 


\section{RADIOLABELING TECHNIQUE FOR EARLY CANCER DETECTIOHA}

Kor words: Radiolabeling; maleimides:

radioimmunodetection; radioimmunotherapy

Researchers in the Nuclear Medicine Group of ORNL's Health and Safety Research Division have developed a new radiolabeling technique that may provide a safe and an effective method for the earty diagnosis and treatment of cancer. This tectnique exploits the immune sys' 3 m's ability to protuce antibodies that target specific proteins produced by cancer cells. It is an improvement over previous techniques for radiolabeling antibodies because the radiolabel (radioactive iodine) remains firmly bound to the antibody.

By chemically binding a radioactive isotope to these special antibodies, the ORNL team has produced new compounds that can carry radioactive isotopes through the bloodstream to a malignant tumor (Fig. 1). In this way, researchers can locate a tumor by using special imaging devices (radioimmunodetection) or, by using a different isotope, destroy cancerous cells (radioimmunotherapy). These compounds can locate a primary tumor early, before it has had time to spread the seecs of cancer throughout the rest of the body.

In the conventional procedure, radioactive iodine $\left({ }^{123}\right)$ or ${ }^{\left.131_{1}\right)}$ is attached to the amino acid tyrosine, which is a part of the antibody.

However, using conventionally radioiodinated antibodies for cancer diagnosis or treatment has the drawback of in vivo deiodination (the release of iodine from the labeled antibodies injected into

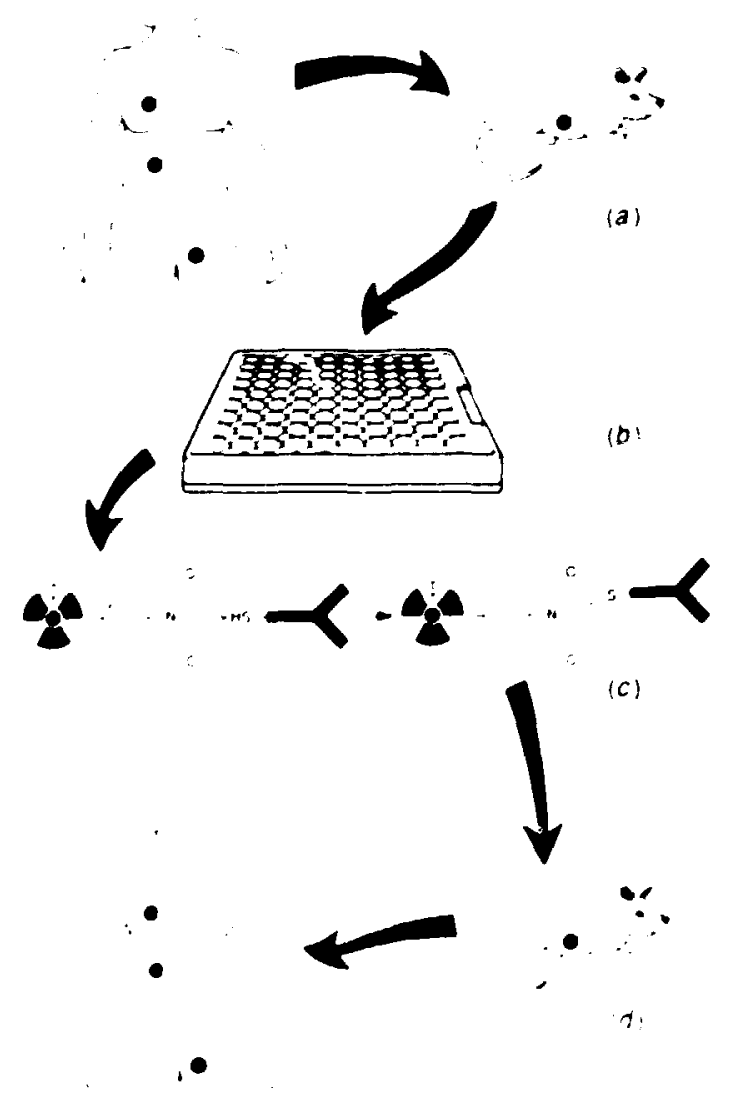

Fig. 1. Stepe involved in the preparation of radiolabeled antibody for immunodetection and therepy of cancur. (a) Tumor celts from a cencer petient are injected into a mouse; the mouse produces antibodies specific to entigens produced by the cancer calls. (b) The entibody-producing colle are cloned and produce more entibodies. (c) Antibodies from the cloned calle cen be labeled with redianctive iodine by meane of the ORNL technique. (d) The lebeled antibodies corry the isotope to the cencer site, initially in test enimale and then, if successful, in humen cancer potiants. 
the body). Two problems are caused by in vivo deiodination: the therapeutic in vivo half-life for the radiolabeled antibody is reduced, and unwanted, potentially cancer-causing radioactive iodine becomes trapped in the thyroid or stomach, resulting in an increased exposure to radiation.

The technique developed at ORNL minimizes daiodination. The researchers designed and synthesized a new radiolabeled maleimide agent lan organic compound containing nitrogen, hydrogen, and oxygen), which can be covalently attached to a benzene ring (phenyl) that includes a stably bound ${ }^{125} 1$ atom. The new imaging agent, called iodophenylmaleimide, can be prepared using an iodine-resctive mercury acetate maleimide kit developed at ORNL. This imaging agent has a strong affinity for the sulfhydry (thicl) group that is naturally or artificially attached to an antibody.

Although $126 /$ was solected for experimental reasons, the new agent could also be labeled with ${ }^{123}$ / for diagnosis or with ${ }^{131}$ / for therapy. Other radioisotopes that could be used with modifications of functional groups on the maleimida agent are indium-111 ( ${ }^{11}$ In), vttrium-90 $\left({ }^{90} \mathrm{n}\right.$, and rhenium-188 $\left({ }^{180} \mathrm{Re}\right)$.

A preliminary study carried o't at the University of Michigan, using nude mice implanted with melanoma and colon tumors, showed that the ORNL maleimide agent can label antibodies that seek out these types of cancer cells and that in vivo deiodination of the laboled antibody is insignificant (Fig. 2). Studies done with rats at OANL compared the performance of the ${ }^{125} 1$-maleimide-lavaled antibody with the performance of conventionally prepared $\left({ }^{131} 1\right.$-tyrosine-linked) antibody and confirmed that using the ORNL agent results in less release and therefore less thyroid uptake of the radioactive iodine.

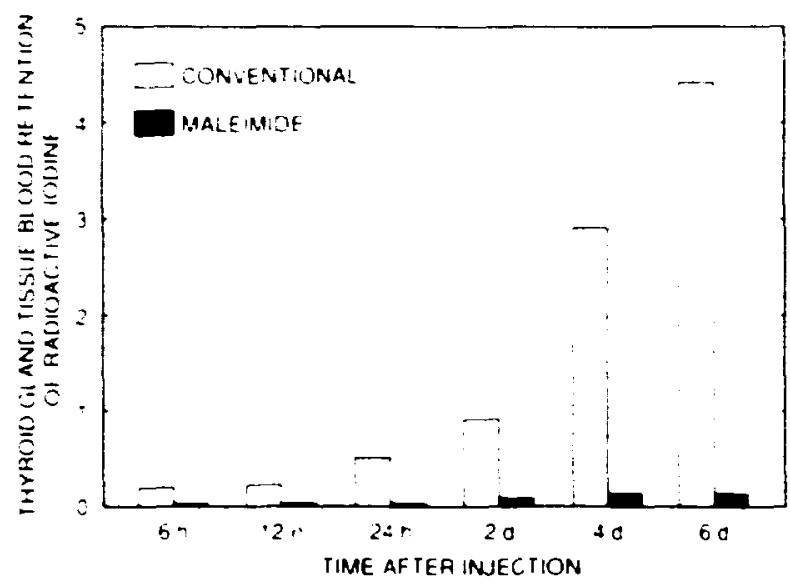

Fig. 2 . In studies at the University of Michigen using nude mice, the makimide-bobeled entibody reculted in dramatically lower lodine uptake in thyroid gland theus compered with bodins uptake from use of the same amoumt of antibody labeled by the conventional technigus uaing trroaine linkege. The low thrroid upteke indicates a relatively hioh in vive stability of the OAML-doveloped egemt, lodophenywaleimide.

U.S. Patent Number 4,735,792,

"Radioiodinated Maloimides and Use as Agents for Radiolabeling Antibodies," has been granted for this technology.

\section{Additional information:}

Office of Technology Applications Martin Marietta Energy Syeterns, Inc. P.O. Box 2008

Oak Ridge, TN 37831-6257

Telephone: (615) 574-4192; fTS 624-4192

P. C. Sivastava. "Now Radiolabeling Techniqua May Aid Early Cancer Detection," Oak Ridge National Laboratory Roviow $21(1), 34 \cdot 5$ (1988).

P. C. Srivastava, "Radioiodinated Moloimides and Use as Agonts for Radiolabeling Antibodiss," U.S. Potent $4.735,792$ (1988)

P. C. Srivastava of al. "Evaluation of $\mathrm{N}-\left(\mathrm{p}-\left[{ }^{128} \mid\right]\right.$ rodophenvimalermide for Labeling Monoclonal Antibodies," pp. 296.97 in Seventh Internotional Symposium on Radropharmacoutical Chemistry Abstracts. University of Groningon. the Netherlends, 1988. 


\section{TRIPLE-EFFECT ABSORPTION CHILLER USING TWO REFRIGERATION CIRCUITS}

Key words: Absorption chiller; absorption refrigeration; refrigeration; air-conditioning

In the United States, most large buildings are air-conditioned using electrically driven chillers. Absorption chillers, which are driven by natural gas, provide an alternative to electric chillers. However, currently available absorption chillers that use conventionel single-effect and doubleeffect cycles are relatively inefficient compared with good electric chillers. A new, triple-effect absorption circuit using two refrigeration circuits (Fig. 1), which greatly improves cooling efficiency of absorption systems, has been designed and demonstrated with computer simulations at ORNL.

Conventional absorption chillers are not economical in most parts of the United States, but because of high foreign fuel costs and scarce electricity, single-effect and double-effect chillers are widely used and are growing in use annually etsewhere in the world. In the late 1960s, U.S. manufacturers were virtually without foreign competition for the sales of absorption chillers workdwide. However, since the early 1970s, the Japanese have been steadily improving the conventional double-effect chillers. Japanese

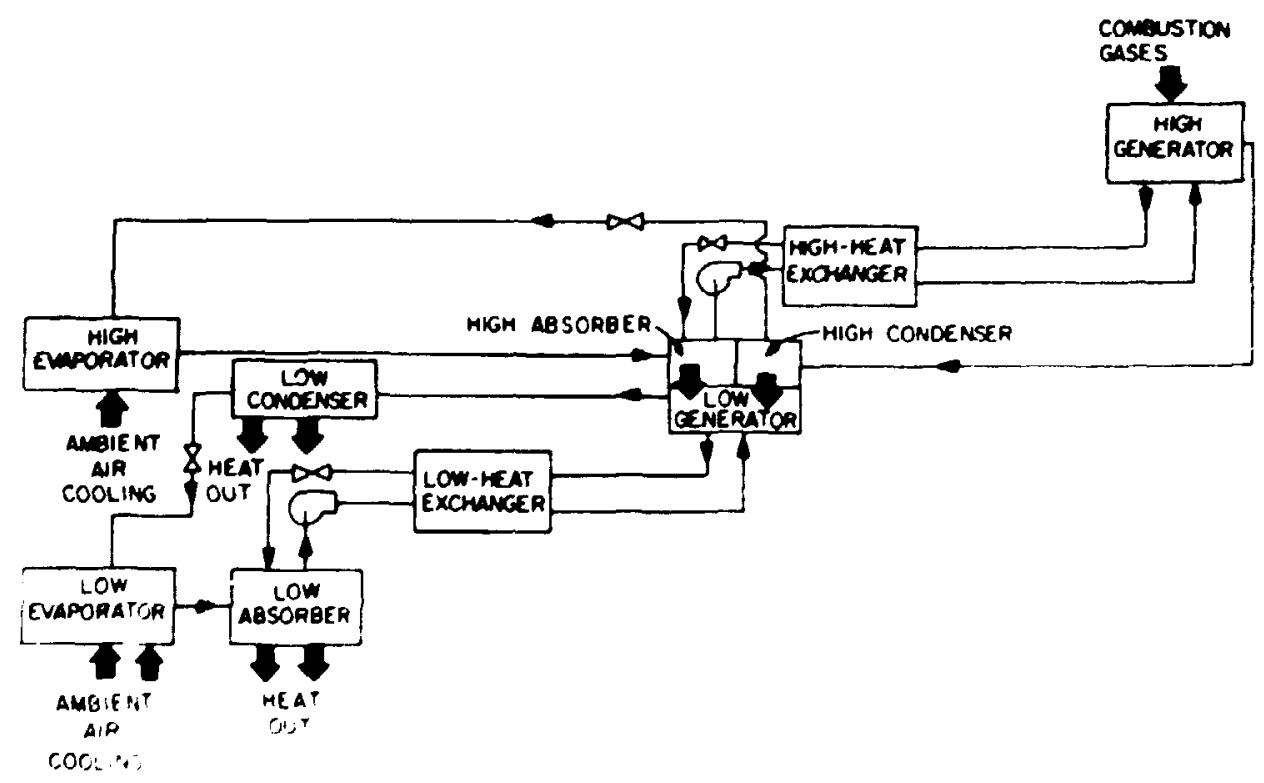

Fig. 1. Diegrem of the new triple-effect sbsorption chiller using two refrigeretion circuits. 
manufacturers now dominate world

manufacturing and sales of absorption chillers.

The new triple-effect absorption chiller concept developed at ORNL is calculated to be 30 to $60 \%$ more efficient than the best equivalent double-effect chiller now manufactured by the Japanese. In addition, because the triple-effect cycle uses heat more efficiently than doubleeffect cycles, the total heat-exchange requirements for the triple-effect cycle are less than they are for double-effect cycles, making the triple-effect chiller potentially less expensive to build. Figure 2 shows the energy efficiencies of all existing technology compared with the tripleeffect efficiency levels.

In an absorption refrigeration circuit, a primary fluid (refrigerant) in a gaseous state is absorbed by a secondary fluid (the absorbent). This absorbent/refrigerant combination is known as a solution pair. Heat absorbed by the refriggrant vapor is transferred to the absorbent and rejected by the absorbent to a heat sink. Heat from an external source is supplied to maintain the continuity of the cycle. Currently, absorption chiller designs include single-effect, double-effect, and dual-loop systems.

The cooling efficiency, or coefficient of performance (COP), of a cooling system is determined by the ratio of cooling effect to heat

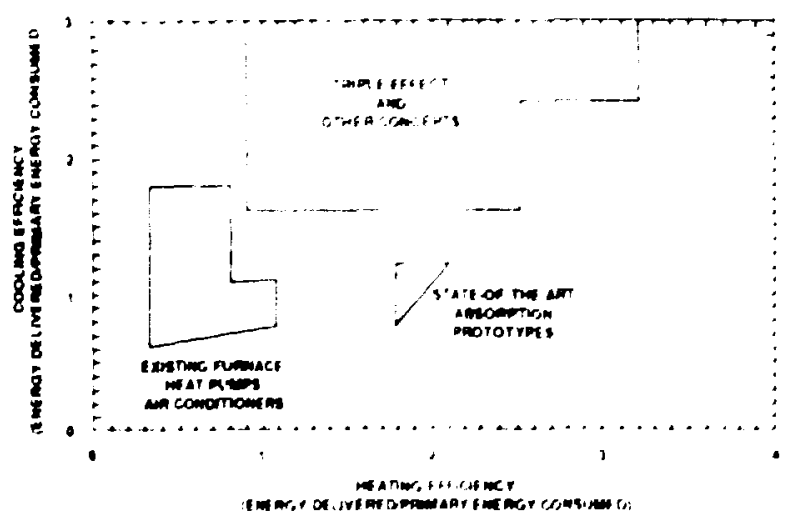

Fig. 2. Abeorption cycles heve been identified with performence potential well boyond current technology. input. The COP of single-effect chillers is typically between 0.5 and 0.7 . Performance can be improved to COPs between 0.7 and 1.25 by using the double-ffect evaporation principle and a double-effect system, in which external fuel energy can be effectively used twice in the highand low-temperature generators. The efficiency of dual-loop cycles is about the same as that for double-effect cycles in air-conditioning and refrigeration applications.

The new triple-effect absorpticn chiller design viekds a cooling COP of about 1.7 to 1.9. Two distinct single-effect refrigeration circuits, operating at high and low temperatures, are combined to effectively use the external heat input three times. A modification to a typical refrigerant/absorbent solution pair allows the high-temperature circuit to operate at a higher temperature than can be obtained compared with conventional double-effect solutions The reject heat of both the condenser and the the absorber of the high-temperature circuit is directed to the generator of the low-temperature circuit. thereby producing about $50 \%$ more refrigerant vapor than double-effect chilters can.

U.S. Paten: Number 4,732,008 has been granted for the triple-effect absorption chiller.

\section{Additional information:}

\footnotetext{
Otfice of Technology Applications

Martin Marwetra Energy Systems. inc

P.O. Box 2008

Oak Rirge TN 37831-6257

Telephone $1615,574-4192$. FTS 624-4192

A C. C... . ault "Tripte Effect Absorption Chater Uitimg

INr. Fu." garation Circuits U. U. Patent No. 4.732.008

(Ma: it 1988)

R C U. vididi, "DOE Absorption Program Overvow." of int, 11,9 in Procedings of the 2nd DOE ORNL Hes:

Piums i i. itarence Research and Development on Hest

Pumps. Space Conditioning Applications. Crystal Gateway

Marriell Washingron. O.C. April 17-20, 1988. Oak Audge

Natuonai i atratatory. August 1988
} 


\section{SEVEN-EFFECT ABSORPTION CHILLER USING THREE REFRIGERATION CIRCUITS}

Key words: Absorption chiller; absorption refrigeration; refrigeration; air-conditioning; heating

The seven-effect absorption chiller is a concept currenty being studied at ORNL. This new absorption chiller design, which uses three refrigerant circuits (Fig. 1), car: be used as an absorption cycle for air-conditioning. Various configurations of this cycle are also possible that would provide heat during the winter.

Absorption refrigeration cycles are heatoperated cycles in which a primary fluid (refrigerant) in a gaseous state is absorbed by a secondary fuid (the absorbent). This

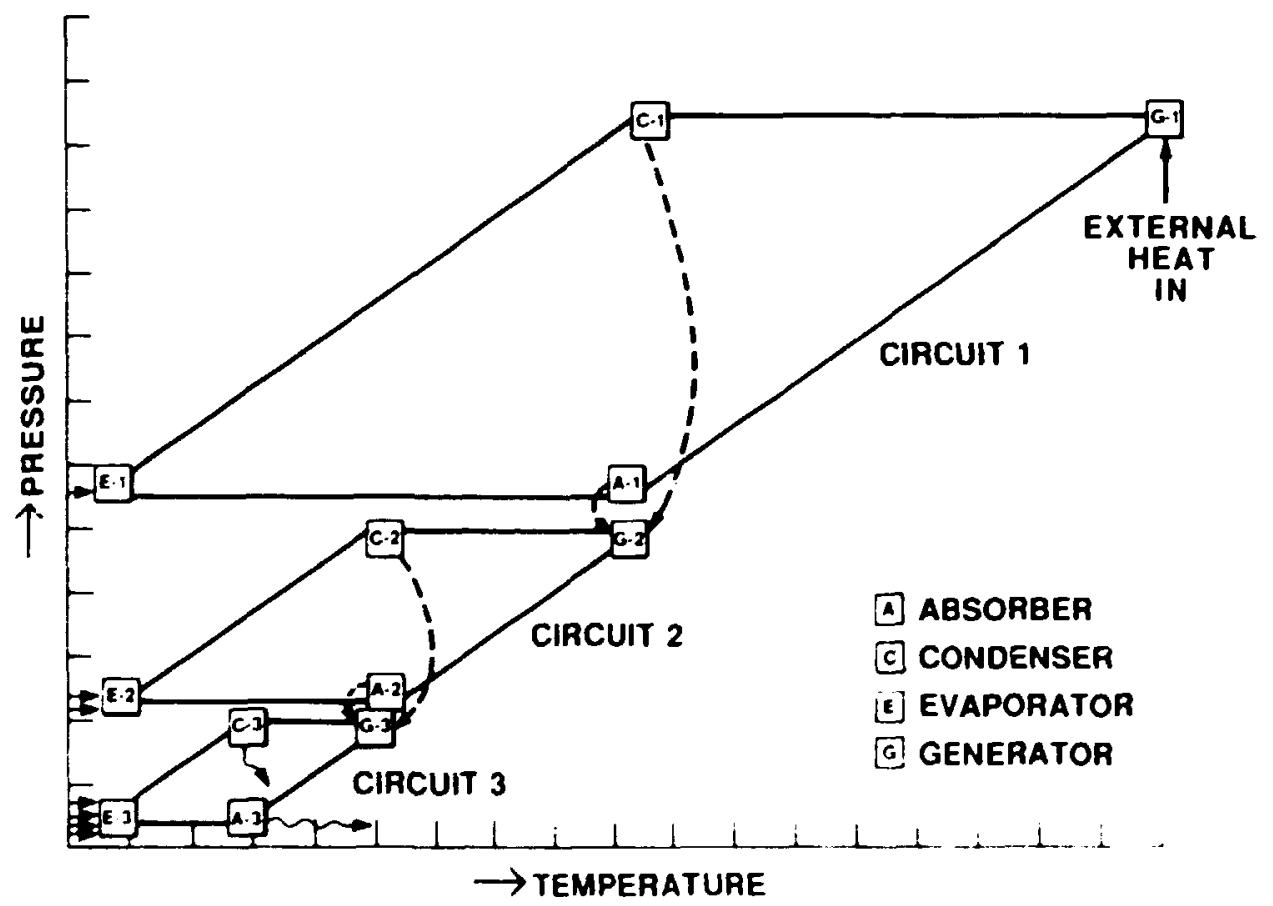

Fig. 1. The eoven-effect ebeorption cycle. A heet exchanger trensfors reject hest from the condenser and -beorber from circuit 1 to circuit 2 and from circuh 2 to circuit 3. This concopt produces 1 unit of refrigerstion effect in the high-temperature eveporotor (circuit 1). 2 units in the medium oveporetor (circuit 2). and 4 units in the lower eveporetor (circuit 3), vietding a total of 7 units of reftigeration effect for 1 unit of external thermal enorgy. 
absorbent/refrigerant combination is known as a solution pair. The unique feature of the seveneffect chiller is that three thermally coupled single-effect absorption cycles operate to effectively use heat input seven times, thereby increasing efficiency substantialty. It is not possible to use the same solution pair for all three single-effect cycles; different solution pairs can be selected to maximize efficiency.

Because of its higher efficiency, the seveneffect system would use less than $50 \%$ of the primary energy needed to drive the best airconditioning systems now available. This new concept offers the potential of an improved coefficient of performance (COP), the measure of efficiency given by the ratio of heat energy extracted for cooling (or heat added for heating) to the work needed to operate the cycle. The
COP for the seven-effect absorption chiller is in the range 2.19 to 3.12 . By comparison, the COP of a single-effect absorption cycle is typically 0.5 to 0.7. More-efficient double-effect and duatloop cycles both have about the same COP 11.0 to 1.21.

\section{Additional information:}

Office of Tectinoloor Applications Mertin Meriete Eneroy Systems, inc. P.O. Box 2008

Oak Ridoo, TN 3783i-E s7

Telephon: (6 15) 574-4192; FTS 624-4192

No turther documantation is wablo for this technalogy. 


\section{Technology Applications Bulletins}

Bullotin Number 686

Oak Ridge National Laboratory

ENERGY CONSERVATION

\section{BUILDING FOUNDATIONS RESEARCH AGENDA}

Key wordx: Building foundations; thermal efficiency; research program

A significant amount of heat is lost each year in the United States from houses with poorty insulated foundations. Most of these foundations have substantial surface area and less resistance to haat loss than a double-pane window. Little had been done to reduce this waste of energy until ORNL conducted a study for DOE and recommended that a research program be undertaken to provide data for ener gy-efficient foundation design. As a result of this recommendation, the DOE Building Foundations Research Review Pand, composed of buildings specialists from both the public and private sectors, convened to set the agenda for a cooperative research program (Fig. 1).

Members of this panel produced the Building Foundations Research Agenda by selecting and

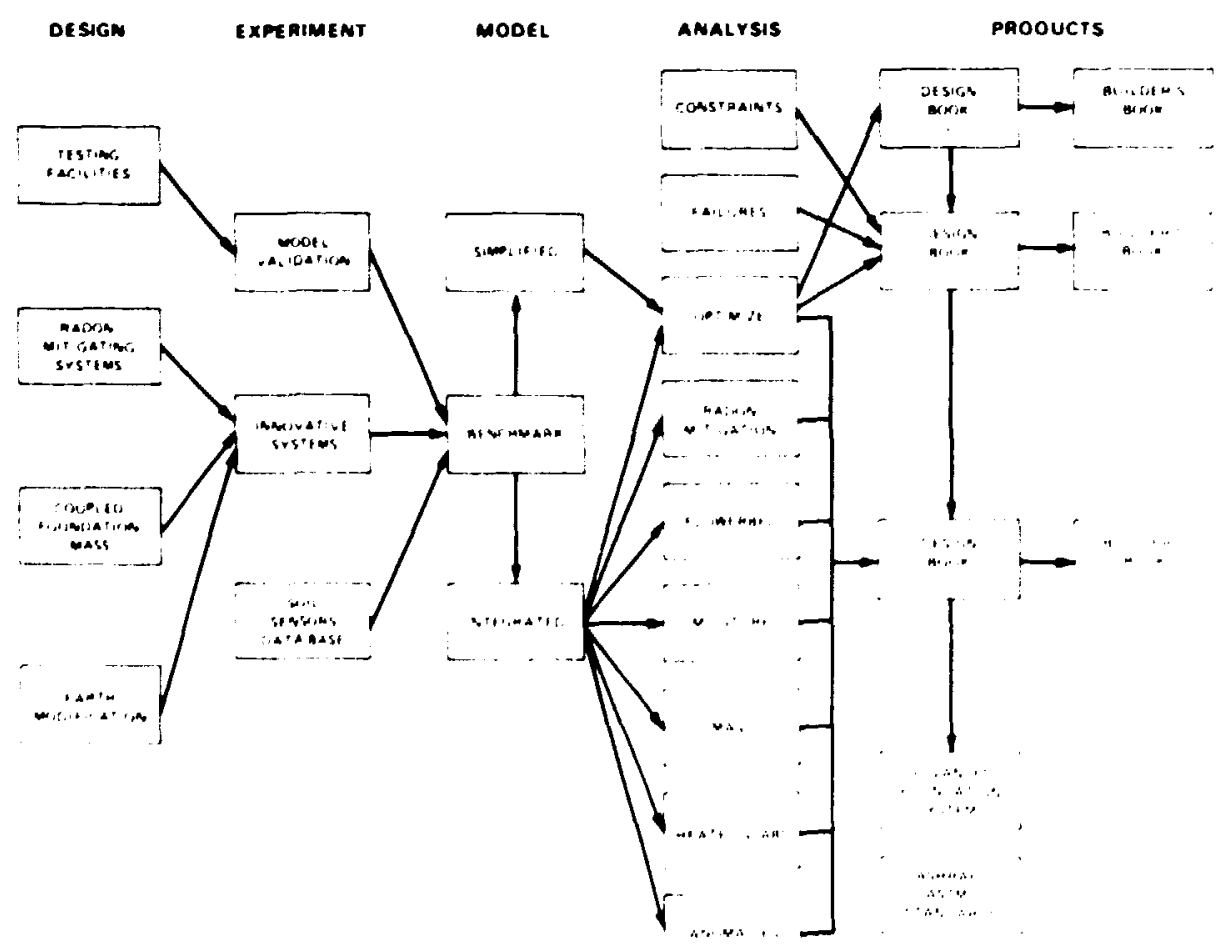

Fig. 1. Flow chart of Bullding Foundations Aesearch Program. 
ranking specific issues concerning the optimization of foundation construction. This agenda addresses the interactions of a variety of factors, including thermal performance, structural integrity, indoor air quality, radon mitigation. waterproofing, drainage, and moisture migration. The research described in this agenda is applicable primarily to new residential construction with masonry foundations, including slab-on-grade, crawt-space, and basement systems. To a lesser extent. pressure-treated wood systems, foundations for small commercial buildings, and retrofits of existing buiblings are also considered.

The major objectives of this ongoing research are to improve the technical information about building foundations and to disseminate that information effectively to the buildings community. Improvements to the technical base include accurate soil characterization for calculating foundation heat loss, a validated foundation heat- and mass-transfer alc... inm that can be coupled to whole-building simulation models, critical experimental results from one or more well-characterized test sites, and detailed field measurements and design tools that enable builders to estimate the thermal performance of whole buildings. This information will be disseminated principally through publication of research results and handbooks for designers and builders.

The ORNL report. Buiding Foundations Research Agenda, contains the agernda. the detaits of hrw it came into existerice, and a list of the reviow panel members. Thr Building Fuundation Dasign Handbook, propcsed and outlined in this report, has since been written and is currently avaidable. This handbook serves as a companion to the new ASHRAE Standard S0.2. Now Residential Construction.

\section{Additional information:}

Otfice of Tectnologr Applications Mortin Mariette Energy Syatems, the. P.O. Bax 2008

Oak Ridgo. TN $37831-6257$

Telephone: (6 15) 574-4192; FTS 624-4192

DOE/ORML Buiding Foundations Resaerch Reviow Pand and J. Chriatien, Buidting Foundetions Research Agonds, ORNL/CON-222, Oak Ridoe Nationd Laborstory (December 1986).

Kenneth Lebs of al., Buiding Foundetion Dexion Hencbook, ORNL/Sub-72143/1 (May 1988).

\footnotetext{
Ascosernent of the Eneror Sovings Potential of Buiding Foundations Resarch," Bubtin No. 634, Tectnoloor Appications Bullotins. Oek Ridos Nationel Leboratory.
} 


\section{ENERGY CONSERVATION}

\section{AN ENHANCED COMPUTER PROGRAM FOR MODELING ABSORPTION HEAT PUMP SYSTEMS}

Key words: Absorption systems; chemical heat pumps; computer simulation

The need for reliable and effective systemmodeling programs for absorption systems has grown with the development of working chemical heat pumps. Several computer models have been developed, but these models can only simulate a single system having a particular design. flow arrangement, and working material. Researchers at Technion (the Israed Institute of Technolcgy). under subcontract to OANL, have developed a modular, user-oriented simulation program that can be used to model a variety of absorptionsystem configurations. This program, called ABSORB, has been enhanced by further research in ORNL's Energy Division.

The main ABSORB program contains unit subroutunes and property-data subroutines. The nit subroutines contain all the fundamental squations applicable to the physics of standard josorption system components isuch as absorbers, desorbers, evaporators, and condensers). The user can specify individual unit subroutines, which are then called up by the main ABSOAB program. The connection between difterent units is made automatically by the main program, which specifies the output of one to be the input of another. The unit subroutines call on the property-data subroutines for the therrinodymamic properties of the working materiak. This separation between the unit subroutines and property-data subroutines provides the flexibitity for each unit to operate with different working materiaks.

The original code for ABSORB has been modified in a continuing effort to improve its robustness, flexibility, and applicability. Modifications include (1) a revised strategy for solving the system equations. (2) increased modularization of the program, and (3) efforts to employ the code to determine an optimum economic design of a heat pump system.

The solution routine originally selected was written specifically for the simultaneous solution of a system of nonlinear algebraic equations. The revised approach uses a nonlinear optumization program, which permits the user to specify bounds on the variables and inequality relationships among the variables as a part of the problem statement, thus simplifying the treatment of these constraints.

The program was modified to increase its modularity and thereby its readability and its adaptability in regard to future enhancements. This modification was achieved principally by employing separate routines to generate the constraint equations and their first derivatives. Thus, calculations of overall material balance, component material balance, enthalpy balance. heat-exchanger energy balance, and equilibria are 
performed in separate subroutines called by the unit subroutines instead of being calculated in line in each unit subroutine.

The ABSORB code was validated for three systems that use a nonvolatie. lithium bromide (LiBr)-water working material. Computer simulations of single-stage and double-stage heat transtormers and a single-stage chillor (Fig. 1) were validated against experimental data. Given the constraints of the testing. a close correbtion was found between the predictions and the measurements.

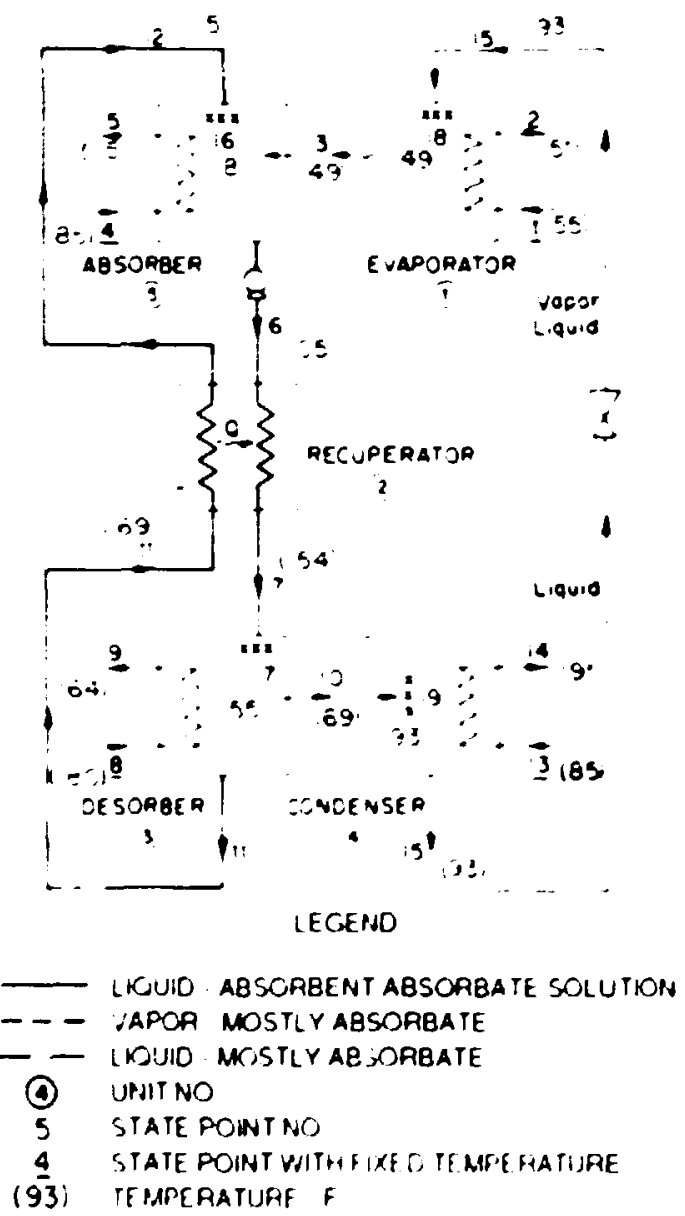

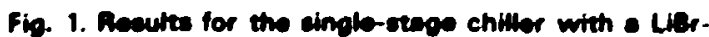
woter working moterial.

\section{Additionsl information:}

Office of Tecthology Applications

Martin Mariete Enargy Systems. Inc.

P.O. Bon 2008

Ock Ridos. TN $37831-6257$

Telaphone: (615) 574-4192: FTS 624-4192

Geration Grosamen end Erabech Michuleon, Absorption Heot Pump Simetrion and Sudies: A Moduter Computer Simintion of Abooption Systems. Find Report.

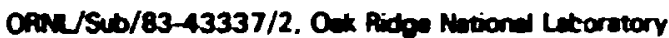
(Apri 1986).

Ficherd L Cox. mprovementas end Enhencuments of th ABSORB Computer Progren tor Modening Chenica Abuorption Mert Pump Sysums. OPav/TM-9957 Whit 1986). 


\section{ENERGY CONSERVATHON}

\section{INFILTRATION REDUCTION FOR SINGLE-FAMILY HOUSES}

Koy words: Conservation retrofits; low-income housing: infiltration reduction

Standard infittration retrofit procedures to improve a house's thermal efficiency often inciude routine caulking or weether-stripping of doors and windows. However, these areas may not be the major contributors to a home's infituration problems; walls, ceilings, attic accesses. fireplaces. electrical outlets, or other aress may also need attention. A house having too little infittration or ventilation can also have problems. Standards must be met to protect the integrity of the structure and the health and comfort of its occupants.

The DOE Office of Buildings and Community Systems' Buidding Energy Retrofit Research Program commissioned ORNL to develop a procedure by which retrofits could be made more efficiently. A joint proisct was carried out, during which ORNL's retrofit audit program was fieldtested and an infittration retrofit procedure developed by the Wisconsin Energy Conservation Corporation was evahuted.

The Wisconsin retrofit procedure employs a blower door, which is a device that either pressurizes or depressurizes a house to aid in locating loaks and to allow a measure of a house's laakiness. Proper use of the blower door can be a great help in identifying and repsiring significant infiltration leaks within a house. A fan is mounted into the envetope of a structure, normally a door (Fig. 1). Varying the speed of the

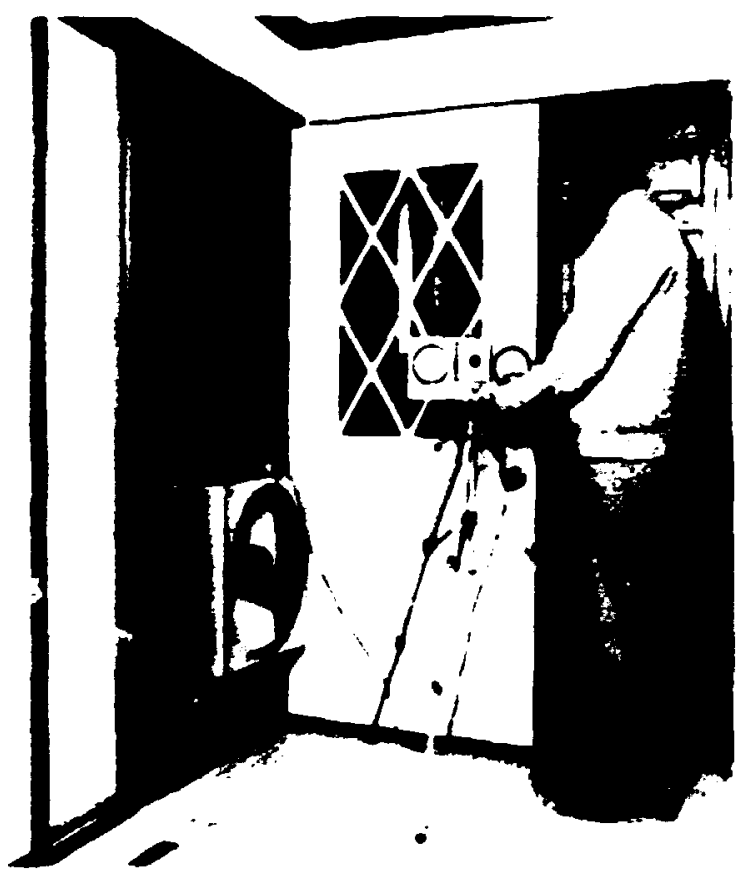

(a)

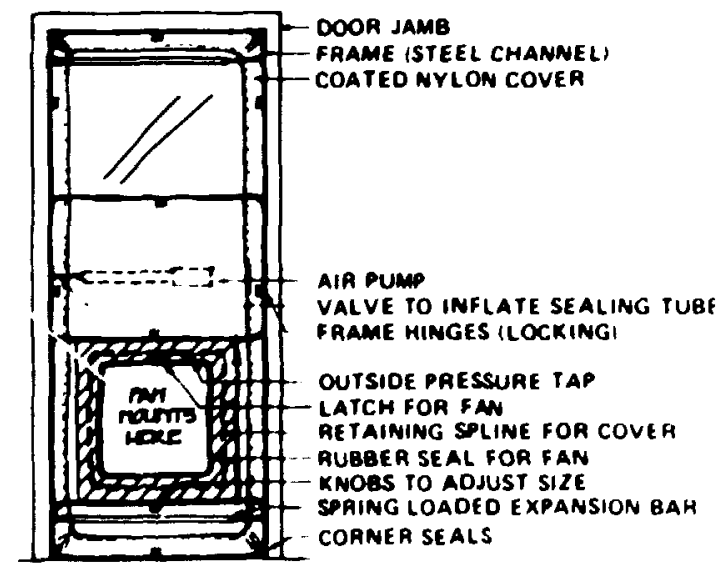

Fig. 1. (a) Blow 3 door installed. (b) Diagrem showing the componente of the blower door necembly. 
fan varies the indoor-outdoor pressure differential. Once this system is operating, leaks can be pinpointed by feeling for drafts or by observing the movement of smoke produced by smoke sticks.

To measuri the effects of infittration retrofits, both the pressure differential and the rate of air flow through the fan are measured. The flow rate through the fan must equal the air-loakage rate from the house at the measured pressure differential. Division of this volumetric flow rate by the house volume gives the number of air changes per unit of time at the pressure differential. For example, the number of air changes per hour at 50-Pa (n-ACH50) depressurization were used in the ORNL study to compare leakage rates before and after retrofits.

The retrofits in this study produced an average $16 \%$ reduction in air-leakage rate. For the seven houses recommended for retrofit, $89 \%$ of the targeted reductions were accomplished with $76 \%$ of the recommended expenditures. The average cost of retrofits per house was reduced by a factor of four compared with previous programs. The average payback period for recommended retrof ts was 4.4 years (based on predicted energy savings computed from achioved airleakage reductions). Although exceptions occurred, the procedure's 8-ACH50 minimum initial leakage rate for advising retrofits to be performed appeared a good choice, based on cost-effective air-leakage reduction. Houses with initial 7-ACH50 leakage rates or below consistently required substantially higher costs to achieve significant air-leakage reductions.

No statistically significant average annual energy savings were detected as a result of the study's retrofits. Measured savings for individual houses varied widely in both positive and negative directions, indicating that the results were affected by factors not considered in the study. Recommendations to improve the retrofit procedure include more extensive training of retrofit crews, checks for minimum air-exchange rates to ensure air quality, and addition of the basic cost of determining the initial leakage rate to the recommended expenditure level.

Recommendations for the field test of the proced. $e$ include increasing the number of houses in the sample, timely examination of metered data to detect anomalies, and monitoring indoor temperatures. Although inappropriate in a field-test procedure, an investigation into the effects of air-leakage rate reductions on heating loads needs to be pertormed.

\section{Additional information:}

Office of Tectunology Applications

Martin Merietta Enargy Systams, he.

P.0. Box 2008

Oat Richo. TN 37831-6257

Telophone: (615) 574-4192; FTS 624-4192

M. B. Gettings, L. N. MaCold, and J. A. Sctriegol, Find Test Evaluetion of Conservation Retrofits of Lowincoms. Singlo-Famity Buidinge in Wiaconain: Blower-Door-Directed infitrotion Procedere, Field Test mplementution and Reauts. ORNL/CON-228/P5, Oak Ridos National Leboratory (June 1988).

Energy-Contarving Rots ofit Audit for Sindo-family Buidings," Bubtin No. 685. Technology Applications Buletina, Oak Aidos Netional Leboratory. 


\section{ENERGY CONSERVATION}

\section{OCCUPANT EVALUATION OF COMMERCIAL OFFICE LIGHTING}

Key words: Commercial lighting: energy standards; design guidelines

Electric lighting accounts for an estimated one-third of the energy used in commercial buildings. Lighting energy standards and design guidelines are important determinants of errergy use in buidings, but because of inadequate empirical data and analysis, these standards and guidelines have been based primarity upon professional judgment. Thus. there is little assurance that recommended lighting values requiring the lowest possible energy use provide optimal user satisfaction and comfort.

A research effort was undertaken to begin developing an archival data base to aid in better understanding the relationship between measures of lighting power density and the quality of the lighting environment. Initiated by the American Institute of Architects Foundation, this research has received extensive review by members of the professional, industrial, and research communities. The results are summarized in a three-volume report published by OANL:

- Volume 1, a description of the research methodology and a bibliography;

- Volume 2, a preliminary analysis of the data; and

- Volume 3, a data archive and a data-base management system.

The research procedure included soliciting information from occuparis via questionnaires and obtaining expert judgments ffor the initiai buildings) from a teem of four experts who walked through the buildings and evaluated the sampled work stations. These subjective responses were complemented by a series of field measurements of photometric, acoustic, and thermal conditions. Conceptually. the process was to treat the subjective responses as the qualitative measures and to compare the unitpower-density and the photometric data against these measures.

This study is considered to be preliminary in nature; with further research, it may provide informed guidance for establishing ligiting standards and other policy issues. Many tentative findings emerged from the analysis. For example. one surprising finding was that lighting satisfaction tends to decrease as lighting power density increases (Fig. 1). Occupants who

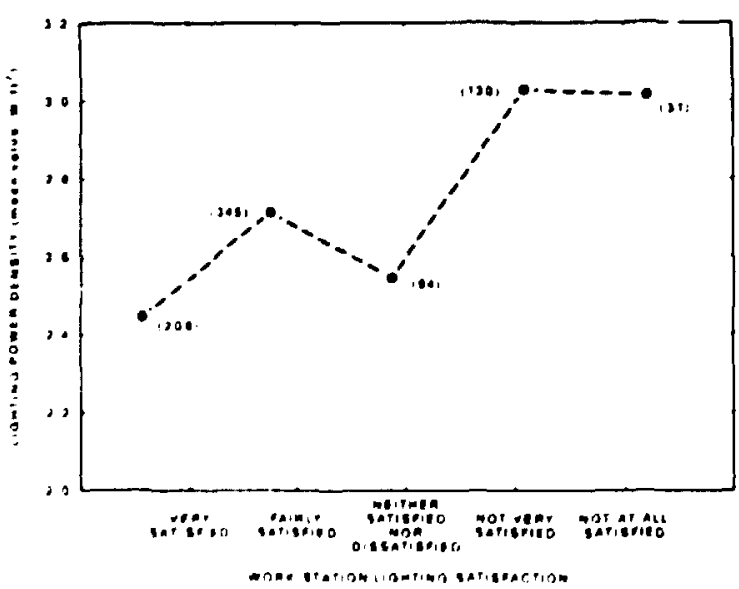

Fig. 1. Work stotion lighting satistaction compared with lighting power deneity. (Numbers in perentheses refer to the numbers of work stetions for which both lighting-power-deneity valuese end occupent responeas have been recorded.) 
described their work station spaces as "dim" a/so tended to be dissatisfied with the lighting at their work stations. Occupants who were most bothered by bright lights and glare were most likely to express dissatisfaction with the lighting at their work stations (Fig. 2). No relationship

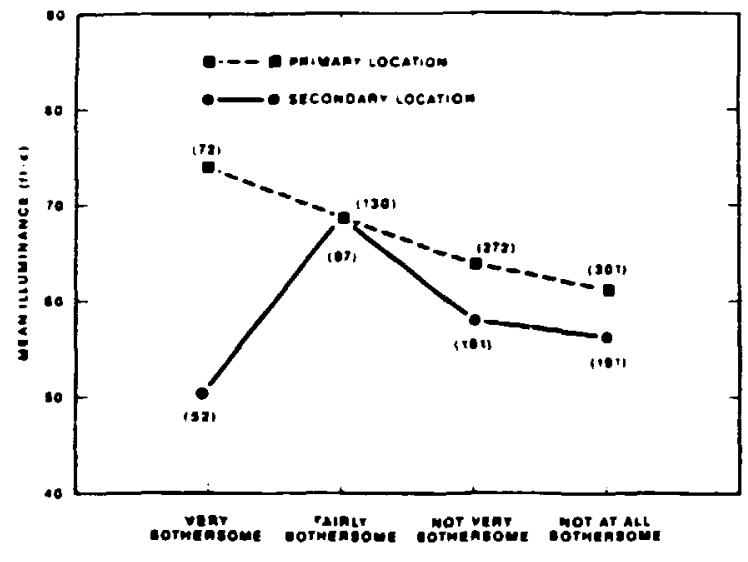

meflicteo elane

Fig. 2. Percelved diecomfore from reflected glere compared with mean imuminance. (Numbers in perentheeses refer to the numbere of work stedions for which both binting-pown-dencity values and cocupant responese hove bean recorded.) was found between work-related activities of employees and indicators of lighting quality.

\section{Additional information:}

National Technical information Service U.S. Depertunent of Commerce 5285 Port Royd Roed Springfiedd, VA 22161

Telephons: (703) 487-4450; FTS 737-4650

G. Gilette and M. A. Brown (ed.), Occupant Evatuation of Commorciel Office Lighting. Vatsme 1: Mothodalogy and Bibliography, ORNL/TM-10264/V1. Oak Ridon Nationd Loboratiry (November 1986).

R. W. Marens and M. A. Brown (ed.), Ocapent Evalution of Commercial Orfice Lighting, Voume If: Prelininery Doto Anaycis, ORNL/TM4-10264/N2, Oak Ridpo Nationel Leboratory (November 1987).

G. Gillotte and M. A. Brown (ed.), Occupent Evatution of Commerciel Office Lighting, Vatumo ill: Dota Arctive and Databece Managament System, ORNL/TM-10264/V3, Oak Ridpe Nationd Leboratory (Auguat 1987). 


\section{Technology Applicotions Bulletins}

Bulletin Number 690

Oak Ridge National Laboratory

\section{ENERGY CONSERVATION}

\section{DOCUMENTATION FOR RESIDENTIAL REFERENCE HOUSE ENERGY DEMAND MODEL.}

Koy words: Computer model; forecasting; energy demand; energy consumption; housing; heating; air-conditioning

The ORNL Residential Reference House Energy Demand Model (RRHED) is a computer-based end-use simulator that forecasts energy demand based on a datailed evaluation of now households use energy for particular appliances. RRHED is a mid- to long-term theory-based engineering and economic stock-adjustmer" model that simulates energy use and the impact of policies over a 20to 30-year period. Energy consumption and policy impects are forecast by fued type and category of equipment (Fig. 1).

The four-volume report. The ORNL Residential Reference House Energy Demand Model IORNLRRHED), documents the RRHED model. It contains an overviow and summary, a user

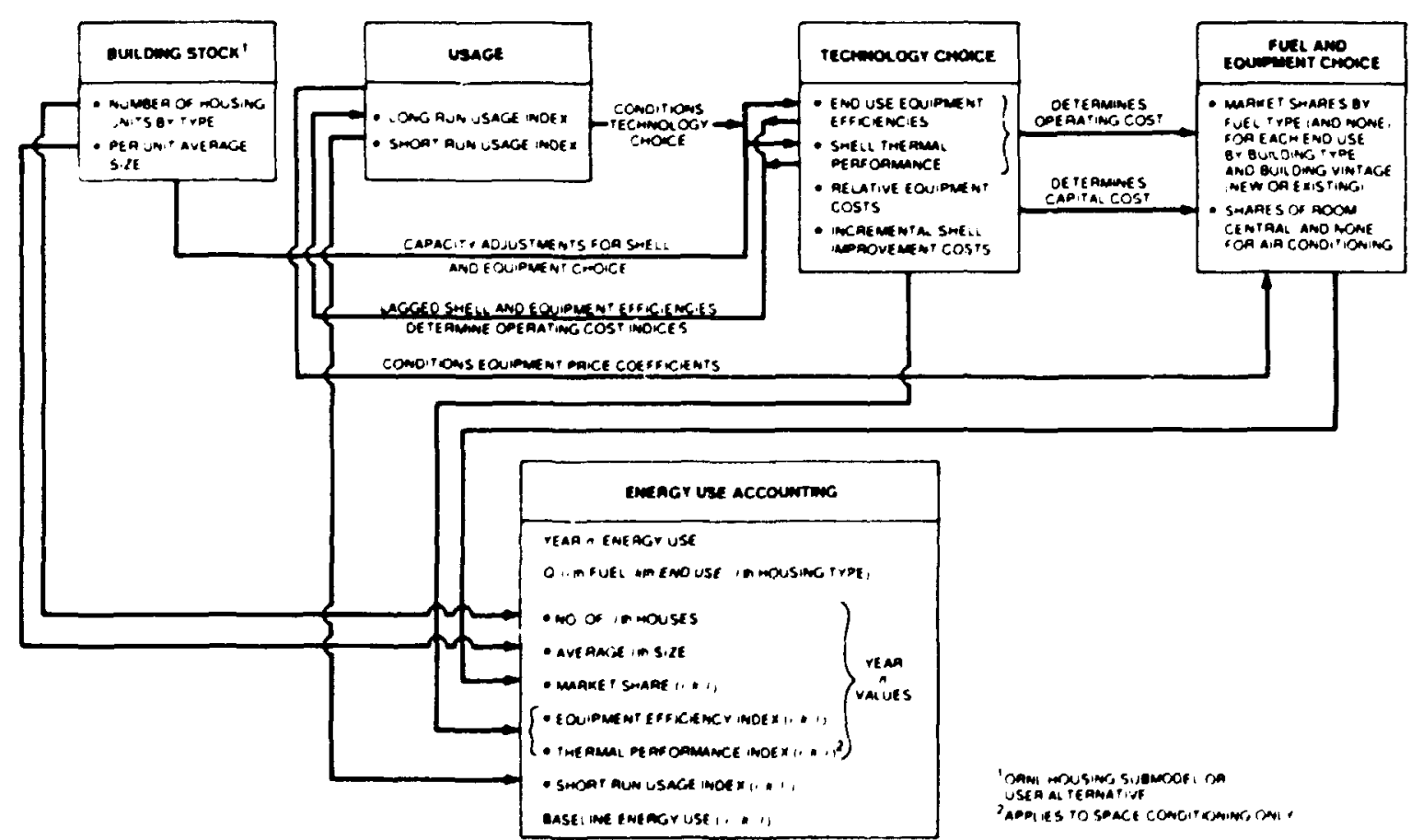

Fio. 1. Interection of modal componemte in the OANLL Reaidential Roference House Enorgy Domand Model. The energy use for each reference house is defined in terms of four major componenta: builling etock, wes, technologr choles, and fuel and equlpment choles. 
reference guide, a technical description of the RAHED model, and a collection of case studies. This report has two main objectives. First, it introduces RRHED to researchers with little background in end-use modeling. Second, it provides the details that a user needs to understand both the theory behind the model specification and the structure of the code. This information will allow the user to modify subroutines for particular applications.

RRHED is currenty being used by a number of analysts throughout the United States. This report provides them with a benchmark for consistent analysis. Also, the user reference guide is necessary because the model is relatively complex and the FORTRAN code used to run it is extensive. Some innovative approaches are applied to general economic problems, which involve the use of sophisticated modeling techniques and novel interactions between engineering and economic data bases. This documentation introduces these approaches to the research community.

The case studies provide examples of how the RRHED model can be used. For example, RRHED was used to predict the influence of proposed building-envelope standards on conservation and fuel choice. These standards were developed by the Northwest Power Planning Council in response to the Pacific Northwest Power Planning and Conservation Act of 1980 (P.L. 96-501). State or local governments within the region were originally required to implement these standards during or before 1986. The focus of the policy analysis study was whether the council standards were as costeffective as alternative supply options.

This analysis raised significant and unresolved issues about social policy and social versus private cost-effectiveness of policy. It is argued that as proposed, the standard policy is neither privately nor socially cost-effective. However, the social and private cost-effectiveness of this policy could be optimal if the standards were implemented in the presence of a market-clearing mechanism that would share benefits among builder, homeowner, and utility.

\section{Additional information:}

Nationd Technical information Service

U.S. Depertment of Commerce

5285 Port Royd Road

Springfield, VA 22161

Telephone: (703) 487-4650: FTS 737-4650

D. M. Hembin of al. The OPNL Residentid Roference Howso Energy Demend Moded (OANL-RAHED) Votume 1. Overview and Report Summery, ORNL/CON-17i, V1, Oak Ridoe Notional Leboratory (Februery 1986).

D. M. Hamblin of al., The ORNL Residentid Roference Howee Energy Demend Moded (OANL-RRHED) Voumo 2. Uner Reference Givid, ORNL/CON-177/V2, Oak Ridoe Nationd Leboratory (Februery 1986).

D. M. Hemblin of al. The ORNL Residential Reference House Energy Domand Moded (OANL-RAHED) Votmo 3. Tochnicel Description, ORNL/CON-177/V3, Oak Rioge Notions Laboratory (February 1986).

D. M. Hemblin ot al., The OANL Residential Roference Howes Energy Domend Model (OANL-RAHED) Votume 4. Cose Studies, ORNL/CON-177/V4. Oak Ridpe Notiond Leboretory (February 1986). 


\section{ENERGY CONSERVATION}

\section{THE PRINCETON SCOREKEEP!NG METHOD COMPARED WITH ENERGY END-USE LOAD DATA}

Key words: Space heating: residential electricity use; electricity consumption; Princeton

Scorekeeping Method; submetered ent-use load data

The Princeton Scorekeeping Method (PRISM) is perhaps the best known and most widely used method to adjust residential energy-use data for differences in winter severity. Research was conducted to determine the accuracy of PRISM results, especially the accuracy of its ability to break down total residential energy use into space-heating and non-space-heating components. PRISM results were compared with submetered data that were gathered as part of the Hood River Conservation Project (HRCP).

The submetered data include whole-house and space-heating electricity uses (recorded at 15-min intervals), weather data recorded at the Hood River Experiment Station lalso at 15-min intervals), and information obtained from detailed on-site home interviews. HRCP's collection of these comprehensive data provided a rare opportunity to examine the performance of PRISM and identify reasons for differences between PRISM estimates and submetered electric load data.

PRISM estimates were compared with monthly load data and actual monthly utility bills. In addition, data for 12 weeks (instead of the usual 1 year) were used to drive the PRISM model to determine if 3 months of data could provide accurate estimates.

The results of this study confirmed that PRISM estimates are in almost perfect agreement with whole-house, end-use load data, but that, on average, it overestimates space-heating eloctricity use (Table 1). The study also revealed that errors in billing data affect the accuracy of PRISM estimates. The accuracy of PRISM estimates based on only 12 weeks of data depends strongly on the season chosen. In general, PRISM

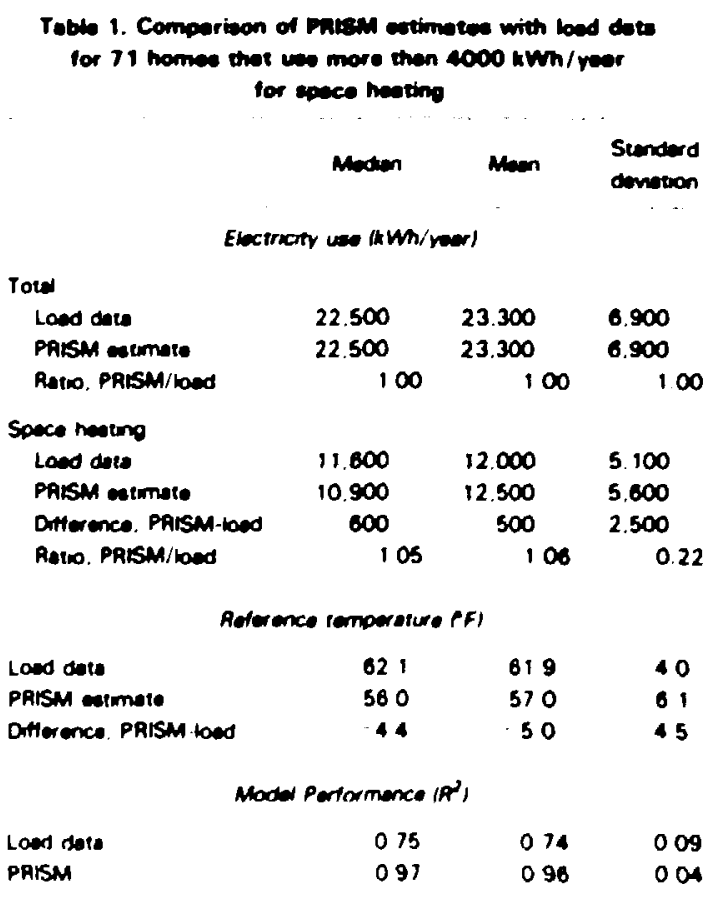


estimates of electricity use for space heating are more accurate for homes that rely primarily on electricity for space heating but do not use much electricity for air-conditioning.

\section{Additional information:}

Office of Technology Applications Martin Meriente Enaroy Systems. Inc. P.O. Bax 2003

Ont fidos. TN 37831-6257

Teluphone: (615) 574-4192; FTS 624-4192
E. Hirst and R. Goultr. Eloctricity Used for Rosidentiel Spect Hastrng: Comperison of the Princeton Scarekeaping Mathod with End Use Lasd Duts. ORN/CON-203. Ond Ridge National Luboratory (Apri 1986).

H. Hwang. Ascessmint of Princeron Scarkkemping Muthod Spece-Hating Estimetes Using End-Use Dote from the Hood River Conservacion Projact. ORN//CON-270. Onk Ridos National Leboratory (Jenuery 1989). 


\section{REVIEW OF NONRESIDENTIAL TRANSPORTATION ENERGY USE DATA}

Koy words: Nonresidential transportation; energy use: data source

\section{Because of the Residential Transportation} Energy Consumption Survey and other surveys. good data are available describing residential uransportation energy use. Data about nonresidential transportation energy use. however, range from very good to virtually nonexistent. An ORNL report written for the Enargy information Administration survers and evaluates the available data.

Data Source Compendium of Non-Residential Transportation Energy Use lists data sources, levels of detai, frequency of publication, time between data occurrence and data availability. and the probability of continued publication. To the extent pussible, the quality of the data is assessed. Data for all modes of nonresidential transportation-highway, air, rail, marine. pipeline, and military-are reviewed. Exhibits of tables from the virious data sources, showing energy-consumption estimates or other data from which messures of energy use may be derived, are inchuded.

For modes of transportation that are the most regulated, a significant amount of data is avaiable. Conversety. for those areas or modes where there is no regulation and the industry itself is rather disjointed. little information is available.

\section{Additional information:}

Office of Tectnoloog Apptications Murtin Mariette Energy Syotems, inc. P.O. Box 2008

Ont Ridos. TN $37831-6257$

Telophon: (615) 574-4192; FTS 624-4192

R. N. MoGil and M. C. Hokcomb, Dots Source Compendim of Nor-Recidentiel Tremeportation Energy Une, ORNL/1M-9329, Onk Ridos Nationel Leboratory (November 1985). 


\section{TECHNOLOGY TRANSFER FOR DOE'S OFFICE OF TRANSPORTATION SYSTEMS}

Ker words: Technology transfer; transportation; case studies; ceramics; reinforced ceramics

Successful transfer of automotive R\&D can have wide-ranging applications throughout the industrial community (Fig. 1). The OANL report, Technology Transfer for DOE's Office of Transportation Systems: Assessment and Strategies, contains a review and assessment of technology transfer efforts by the U.S. DOE Office of Transportation Srstems (OTS). Barriers to technology transfer are discussed, and

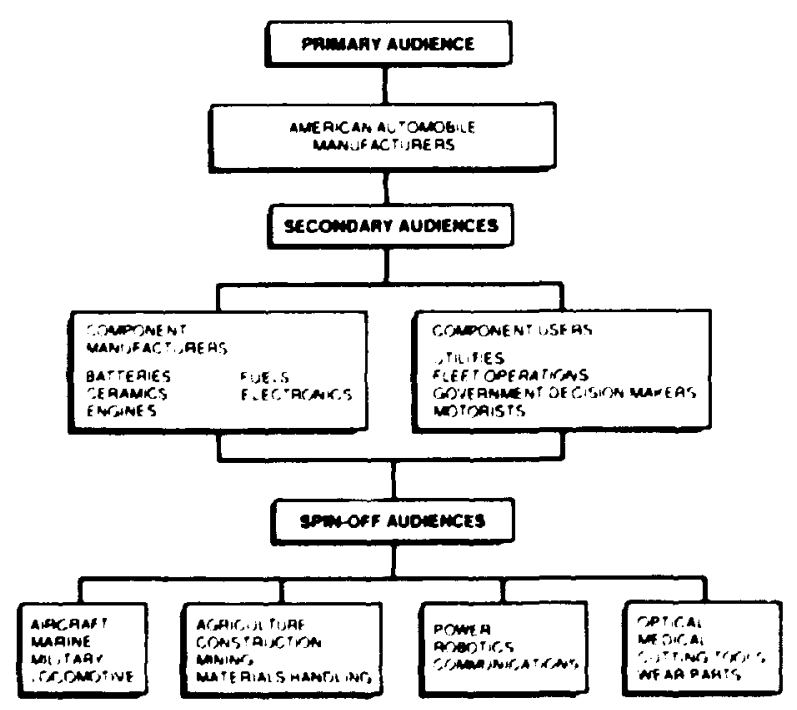

Fig. 1. The primary, eecondary, and spin-of eudiences for technology erenefer efforts by the U.8. DOE Office of Transportation 8yotems. recommendations to improve efficiency are made in this report. An inventory of recent OTS technology transfer efforts is supplemented by nine detailed case studies that demonstrate five distinct approaches to industry:

- contracting to industry.

- licensing.

- demonstration projects.

- user facilities, and

- financial incentives.

One example of how the technology transfer process operates is given in the case study invotving whisker treinforced ceramic composites. In an OTS heat-engine program, a major effort was directed at developing tougher and stronger ceramic materials to meet demanding gas-turbine performance criteria. Because the ceramics industry is typically made up of small concerns having limited RED budgets and research facilities, improvements necessary for the OTS heat-engine program needed to come from outside the private sector.

Development of whisker-reinforced ceramic composites began at ORNL with funding from DOE's Energy Conversion and Utilization Technologies program. OTS sulusequently funded ORNL scientists for further work. The resulting composite consisted of an alumina matrix reinforced with microscopic "whiskers" of silicon 
corbide, which double the toughness of the normally brittle alumina. The new material is $40 \%$ tougher and $25 \%$ stronger than nonreinforced ceramics.

Energy Systems obtained a patent waiver from DOE in 1986. In June 1986. Energy Systems granted a license for the composite to Atiantic Richfield's ARCO chemical subsidiary in exchange for a licensing fee, advenced rovalties, and future rovalties besed on product sales. The royalties are shared with the ORNL inventors as part of an incentives program. Remaining monies are placed in a technology transfer fund to support future development of products and processes.

Additional licenses have subsequently been signed with Energy Systems for this technology. primarily for manufacturing fast, long-lasting cutting tools and other wear parts. At least one of these companies may use the new ceramic in the production of next-generation auto parts. Potential audiences for spin-off development of this technology include manufacturers of siliconchip packaging, radioactive-waste containment. and spececraft external heat protection.

\section{Additional information:}

Office of Technology Application Martin Mariatta Enargy Systems, Inc. P.O. Box 2008

Oak Ridoe, TN $37831-6257$

Telephonv: (615) 574-4192: FTS 624-4192

S. A. Snell, M. A. Brown, and A. Zereas, Technolooy Trensefer for DOE's Office of Treneportation Srotums: Ascosement and Strategine. OANL/CON-244. Oak Ridos Nationd Leboretory (Apri 1988). 


\section{ENERGY PRODUCTION}

\section{WOOD-BURNING RETROFIT SAVES FUEL AT AN OIL-FIRED STEAM PLANT}

Koy words: Renewable resource; wood-burning boiler; waste wood; cost anal/sis

The military services are participating in the Department of Defense Energy Conservation Investment Program (ECIP), in which promising conservation retrofit proiects are identified. justified, and implemented. One such project was undertaken by the U.S. Army at Fort Stewart, Georgia, where a now wood-burning boiler and a wood-conveying system were added to the three oilfirod boilers of the central energy plant

(Fig. 1). This retrofit was undertaken to exploit the abundant waste wood available at Fort Stewart. Its success was validated by a team of researchers from ORNL's Energy and Instrumentation and Controls divisions.

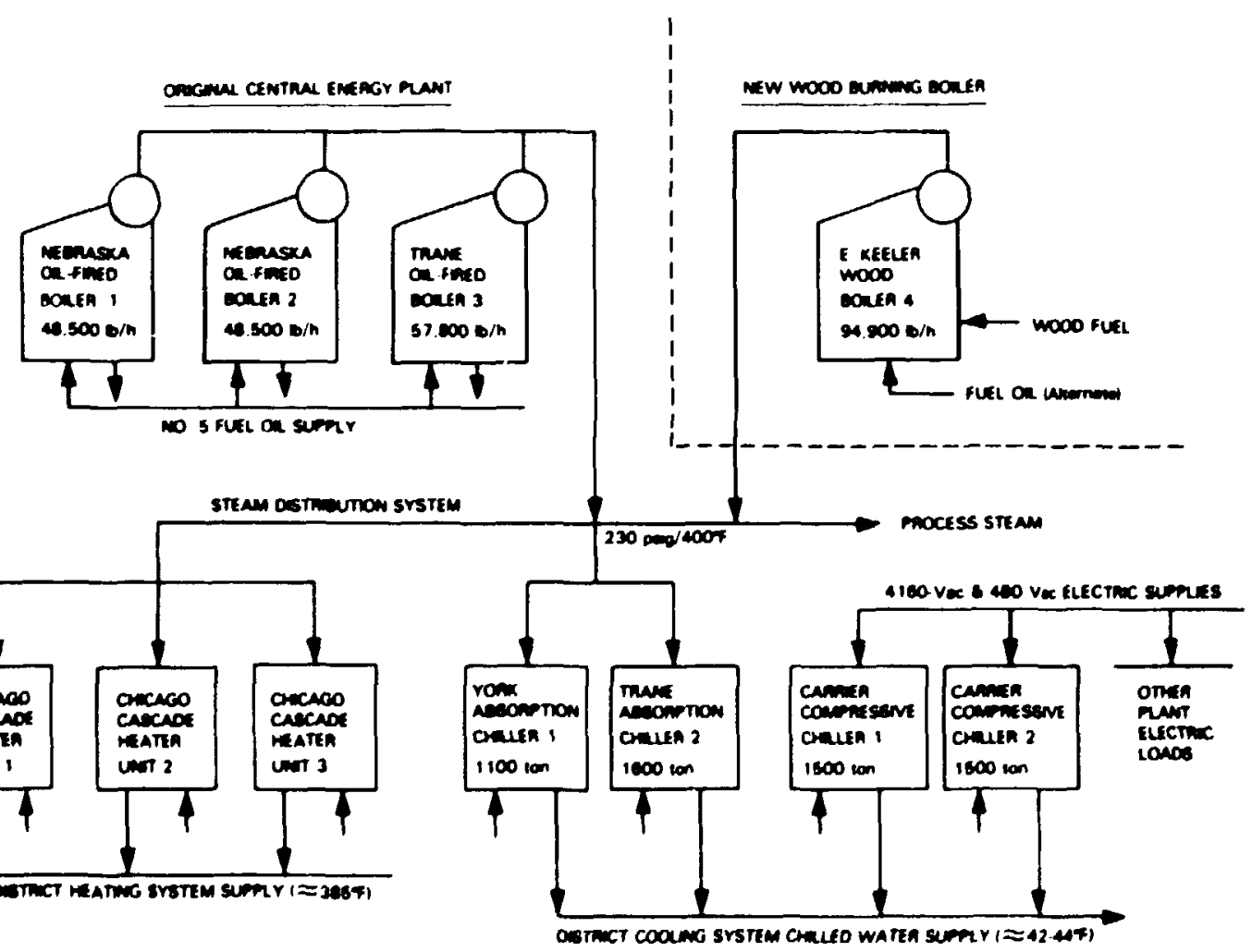

Fig. 1. Bytem degrem for Fort Btewert central energy plent, including the added wood-burning ovotem. 
During the 1-year postretrofit validation study. the ORNL team gathered data about steam production; wood, fuel od, and electrical energy consumption; other necessary plant operations; and ambient temperature. Preretrofit operations were simulated by treating actual postretrofit study data as if the new bolier were not in operation. Preretrofit and postretrofit date were compared to determine cost and energy savings.

During the postretrofit study period, the wood-burning boiler produced about $90 \%$ of the steam required by the central energy plant to meet seasonal heating and cooling demands. Consequently. over $2.88 \times 10^{6} \mathrm{gal}$ of fuel oil were conserved. It was estimated that about $4 \times 10^{5}$ Btu of norrenewable energy can be saved annually by burning waste wood. A lfecycle cost anahysis has projected first-year savings of more that $\$ 1.2$ million. The discounted savings ratio is 3.36, and the estimated simple payback period for the ECIP project is 6.7 years.

In addition to the valuable experience gained that can be applied in designing. building, and evaluating wood-burning boiler plants in the future, the study also shows that a postretrofit data can be used to develop preretrofit simulation data. which can then be used for energy and cost comparisons.

\section{Additional information:}

Natoonal Techncal information Service

U.S. Department of rommerce

5285 Port Royd Rood

Springfiedd. VA 22161

Telephone: (703) 487-4650: FTS 737-4650

M. A. Broders and D. R. Milor. ECP Project Vetidetion Pian: Wood Buming Boiler Plant, Project No. 193. Fort Stower

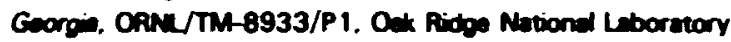
(Miry 1984).

M. A. Brodars and D. R. Milur. Phose H-Derion: ECP Project Vatidion Plan: Wood Buming Baier Pum, Project No. 193. Fort Stowert Goorgi. ORnL/TM-8933/P2, Odk Ridoe Netiond Lboratory (September 1984).

M. A. Broders and D. R. Miver. Phenes I and IL Docion: ECP Project Vatidition Plan: Wood Buming Botur Pient, Project No. 193, Fort Stewert Georgis. ORNu/TM-8933/P2/R1. Od Ridoe Netional Leboratory (Aupust 1985).

M. A. Broders and D. R. Miner, Enorgy and Cost Sovings Andyais of Wood Buming Boiler Plont, Fort Srower Goorgid, OANW/CON-219, Onk Ridos Notionel Leboratory (Auguat 1987) 


\section{ENERGY PRODUCTION}

\section{RELIABILITY STUDIES FOR COMPRESSED-GAS-INSULATED APPARATUS}

Koy words: Gas insulators: SF votrage: failure

Compressed sutfur hexafucorido gas (SF, is currently boing used by the utilities industry as electrical insulation in high-voltage electrical apperatus. Compressed-gas insulated equipment is relatively now in elactric-power technology. Consequenthy, long-term performance data and discriminating test procedures for these devices are somewhat lacking. Bases for comparison among manufacturers are sometimes dificut, and better information about the mechanisms. processes, and rates for low-voltage failures is needed. The uncertain reliability of compressedgas-insulated apparatus has been cause for concern to the vtilities industry.

Reliability studies and experiments were carried out for DOE's Office of Energy Storage and Distribution at the Massachusetts institute of Technology's High-Voltage Research Laboratory. partially with the support of ORNL's Energy Division staff. This project had four broad goals: identify processes important to insulator reliability, model these processes, verity model concepts, and establish criteria for equipment design and specification.

These studies have provided basic information about low-probebility insulation failures and have quantified the failures sufficiently to form the basis for improving insulator designs. They have also provided utilitios with a means 10 better assess the expected performance of specific equipment. For example. factors important to reliability in compressed-gas-insulated apparatus can now be better modeled. Low-probability faitures are better understood and more predictable as a resutt of this research, and recormmendations have been made that can be used for improving and monitoring insulator reliability.

Results of the investigations are summarized in the OANL report, Research Factors That Affect the Reliability of Compressed Gas Insulated Apparatus. This report contains a description of a reliability model, descriptions of the experimental apparatus, procedures and results for highvoltage tests of gas gaps and insulator surfaces. and the results of a full-scale application that combined the concepts developed during the gas-gap breakdown and surface flashover studies. In addition, a collection of journal articles that were generated by this research are reprinted as appendixes to this report.

\section{Additional information:}

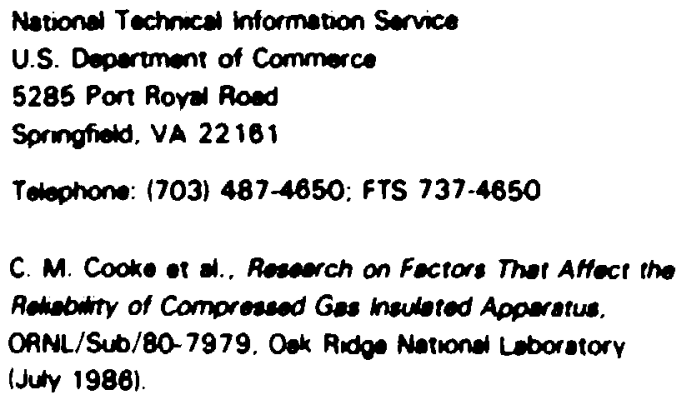




\section{ENERGY PRODUCTION}

\section{ASSESSMENT OF MATERIAL REQUIREMENTS FOR ADVANCED STEAM CYCLE SYSTEMS}

Key worda: Coat-fired generation; advanced steam cycle; tuel efficiency; computer modeling: materials requirements

To offset rising fuel costs and potential greenhouse effects, vtility companies may be lod to invest in higher-efficiency coal-fired power plants to meet future demends for electricity. Use of advanced stoam cycles will increase the operating efficiency of commercial power plants. but cost-effective application of these cycles will require improvements in both designs and materials. Recent Electric Power Research Institute (EPRI) studies have recommended using a supercritical steam cycle (4500 psi, $1100^{\circ}$ ) based on incremental improvements to current plant designs and materials. To this end, EPRI has initiated a 5-year R\&D program with tasks aimed at providing the necessary technology for these plants to meet utility operating requirements. The Japanese have under way a similar program that includes verification of the reliability of structural materials for advanced steam-cycle applications.

A study was performed at ORNL to identify areas in which DOE could carry out appropriate R\&D that would contribute to the required technological advancements, especially in developing materials for advanced steam-cycle coal-fired electric power plants. In general, advanced plant concepts used as a basis for the
ORNL study were derived from the EPRI studies because they considered the most recent industry requirements, including availability, on- and offcycling capability, low-load operation, and fuot flexibility. The Tennessee Valloy Authority's Bull Run Steam Plant was used as a reference for selecting steam-cycle design parameters. Results of the OANL study, including a discussion of steam-cycle modeling and criteria for advanced materials, are found in the ORNL report, Assessment of Material Requirements for Advanced Steam Cycle Systems $>1100^{\circ} \mathrm{F}$.

The thermodynamic performance of the turbine cycle was modeled using PRESTO, a computer code developed at ORNL to model conventional high-pressure and superheated steam turbine cycles (Fig. 1). This model was used to estimate improvements in thermal efficiency stemming from higher temperatures and pressures. From this study, several conclusions emerged about conventional coal-fired plants. For example, fixing main steam conditions at $\mathbf{4 5 0 0}$ ps., improved overall efficiencies, and lower fuel costs are achievable as temperature is increased from 1100 to $1400^{\circ} \mathrm{F}$. However, increases in steam temperature above $1100^{\circ} \mathrm{F}$ produce less significant increases in efficiency without attendant increases in steam throttle pressure. The model also showed that fuel savings over 30 years can offeet higher copital costs. providing that the improved materials have better reliability and strength at higher temperatures 


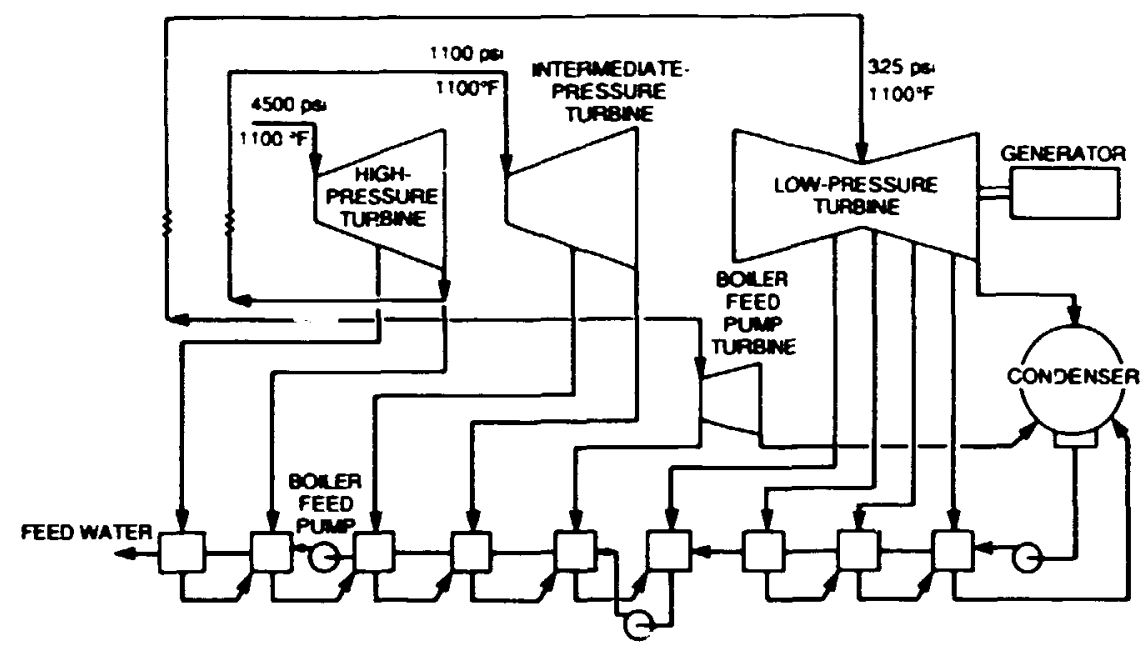

Fio. 1. Adranced steam plant, besed on the OANu PRESTO modeling computer code (eteam conditione: 4500 pei, 1100 F).

than currently used materials. Specification of plant designs required for operation above $1200^{\circ}$ await the development of specific flow charts and further modeling of advanced plant parameters.

The ORNL study concludes that materials developments for applications above 1400 to $1500^{\circ}$ F could be logically incorporated into current materials programs. Because of cost and corrosion considerations, development of improved boiler materials has greater pay-off than development of improved turbine materials.

Allowable materials costs are closely related to allowable design stress; consequently, the attainment of higher efficiency through the development of advanced systems depends on the development of cost-effective higher-strength materials.

\section{Additional information:}

Office of Technology Applications Mertin Meristu Eneroy Systems, inc. P.O. Box 2008

Dek Ridpo. TN 3783 1-6257

Tewophono: (615) 574-4192; FTS 624-4192

J. R. DStefano, J. H. DoVen, and L. C. Fuller, Aseasement of Material Aequirements for Advanced Steam Cyclo Systems D (100\%), ORNL/TM-10489. Oak Ridos Nationd Laboratory (Februery 1888). 


\section{ENERGY PRODUCTION}

\section{STUDY OF SOLAR POWER SUPPLY SYSTEM AT MISSISSIPPI COUNTY COMMUNITY COLLEGE}

Koy worda: Solar power; photovoltaic/thermal array

The installation of a solar-powered photovoltaic/thermal system at Mississippi County Community College in Btytheville, Arkansas, was completed in 1981 . Originally, this system was buitt to supply the college with heat, hot water, and electricity (Fig. 1). Installing this system was one of the earty major soler power projects funded by DOE.

In 1984 this system was converted for alt thermal output. It operated during the winter of 1984-85 until it was damaged by a severe winter storm. A study published by ORNL, Mississippi County Community College Solar Power Supply System: Final Summary Report.

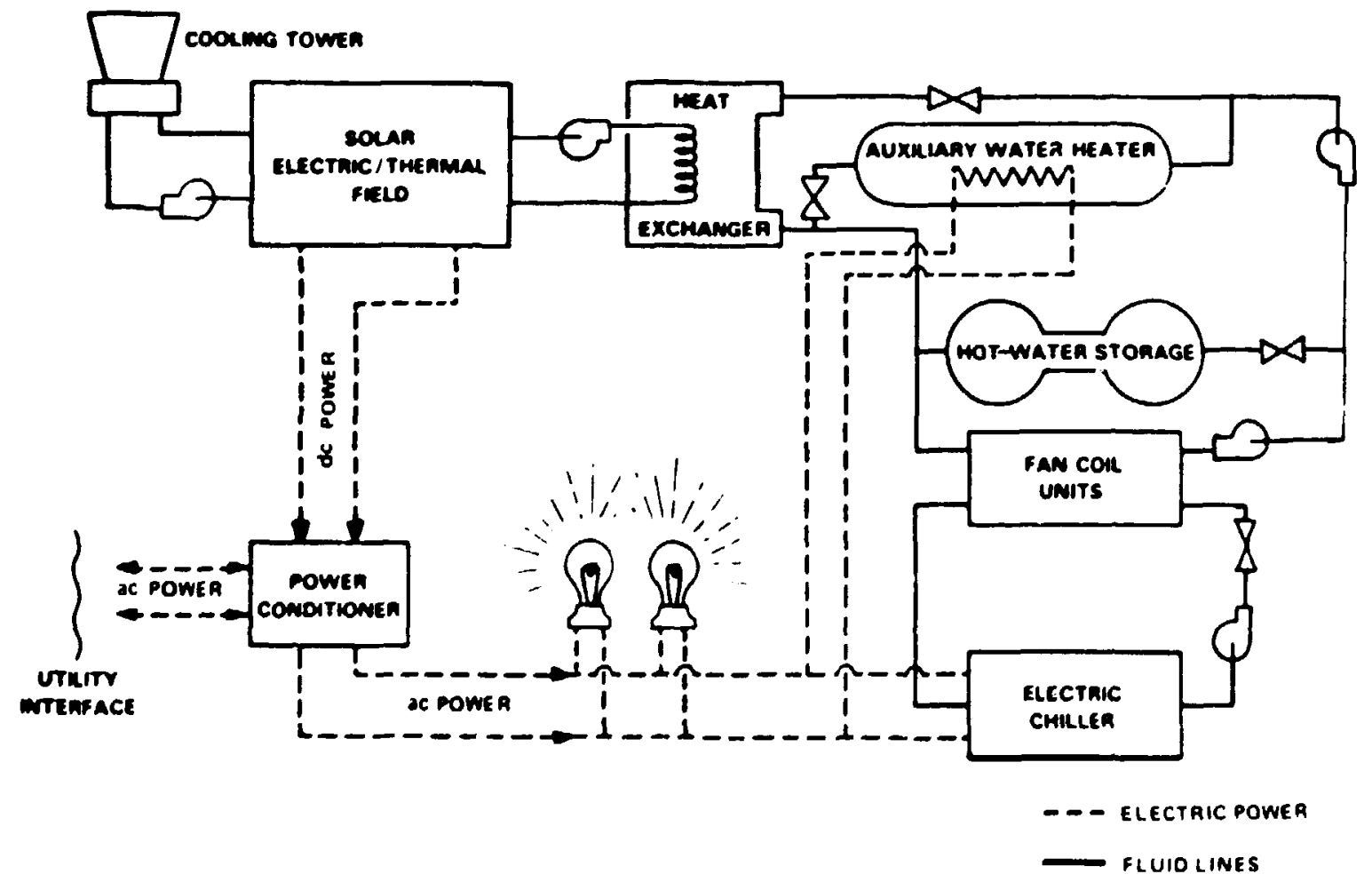

Fio. 1. Flowchert of Miselselppi County Community College soler eneroy aystem. 
summarizes ivhat was learned during

photovoltzic/thermal (PV/T) oporation. The less extensive information available for the all-thermal system is also reviewed in this report.

The PV/T array consisted of $\mathbf{4 5}$ rows of linear parabolic reflectors with their axes oriented north-south. Each row contained six reflectors (Fig. 2) mounted end to end on a common shaft that could be rotated through an arc of $270^{\circ}$. The system was operated and monitored by a Hewlett-Packard 9845 computer. In the conversion to all-thermal operation, the array was reduced from 4 is to 33 rows of reflectors.

The PV/T system was never able to exceed $55 \%$ of rated electrical output. The performance inadequacies are thought to have been caused $b_{y}$ inherent problems in the concentrating PV design rather than by operating or maintenance shortcomings. Preliminary estimates suggest that the all-thermal system was more successful; its thermal energy output exceeded that of the older $\mathrm{PV} / \mathrm{T}$ system in spite of the fact that its collector area was $27 \%$ smaller.

\section{Additional information:}

Office of Tectunology Applications Martir Marietta Energy Systems, inc. P.O. Box 2008

Oak Ridge. TN 37831-6257

Telephone: (6 15) 574-4192: FTS 624-4192

S. I. Kaplan. Mississippi County Community Callege Solar Power Supply System: Find Summary Report. OANL/TM-9859, Oak Ridge National Laboratory (February 1986)

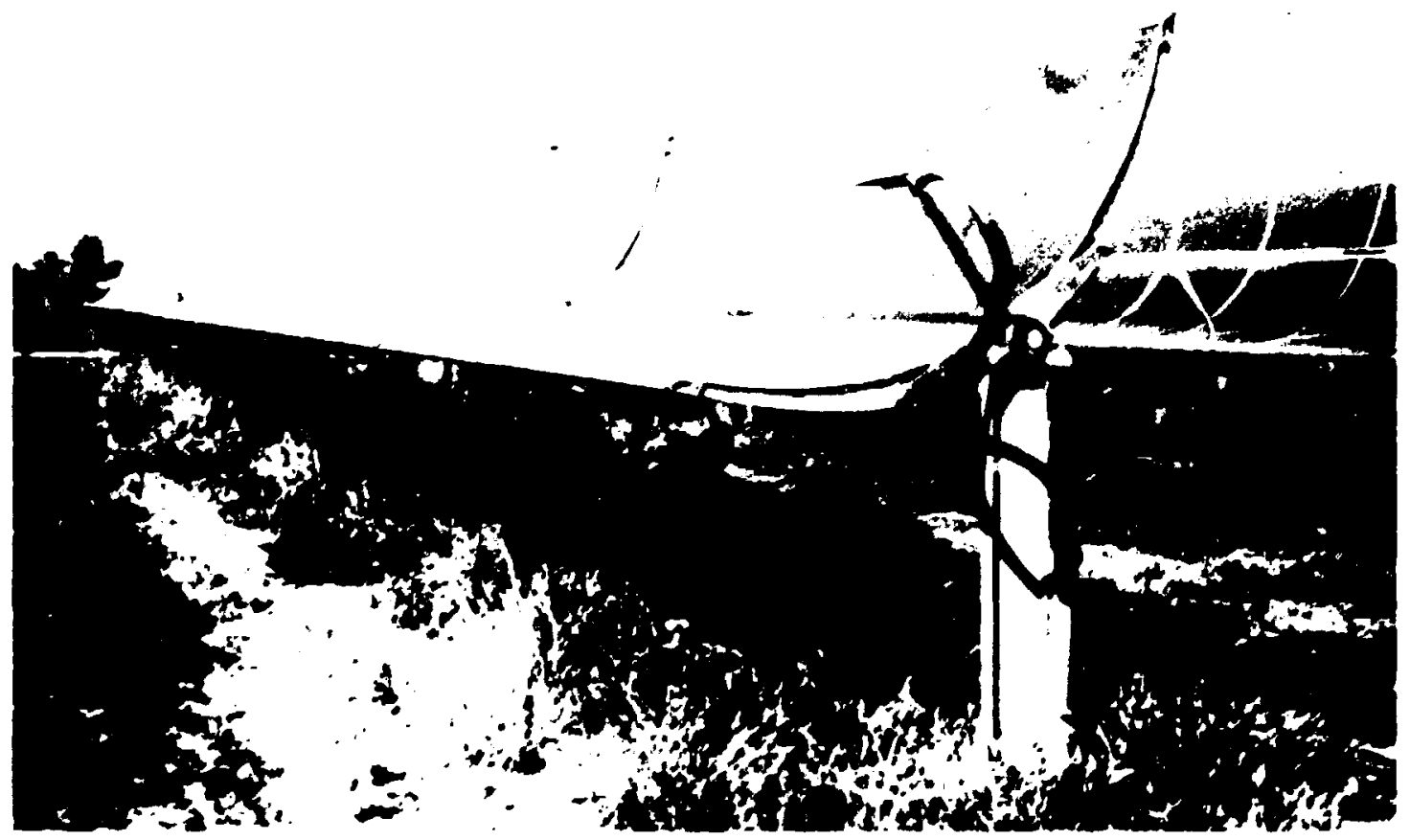

Fig. 2. Miediedippl County Community Colkge solar colbetor row. 


\section{ENERGY PRODUCTION}

\section{AN ALL-METAL REENTRANT VACUUM FEEDTHROUGH}

Key words: Vacuum seal; reentrant seal; allmetal

Researchers in ORNL's Fusion Energy Division have designed, built, and tested a demountable, all-metal reentrant vacuum feedthrough for use with the Advanced Toroidal Facility (ATF) diagnostics. This type of feedthrough is required for diagnostics containing electrical coils that $\pi$.ust permanently remain in place in the vacuum chamber. The new design is different from commercially available all-metal feedthroughs in that is allows the vacuum vesset port cover to be removed while leaving the internal diagnostics in situ. This new feedthrough has been proven to remain leaktight at temperatures above the bakeout tomperature of the ATF vacuum chamber $\left(150^{\circ} \mathrm{C}\right)$.

A cross-sectional view of the seal is given in Fig. 1. The seal is composed of two flanges whose mating suriaces are mbchined to accept a standard Conflat copper gasket (b). One flange (a) is woided to (or machined into) to the vacuum chamber's port cover, ar.jund the penetration that it will seal. The second flange (c) is attached to the base of an extension that passes through the penetration. The tube passing through the vacuum chamber port cover is welded to the external end of the extension. A jacking ring (e), which is drilled and tapped to accept a cirche of jackscrews (d), attaches to the extension by either a threaded connection or a

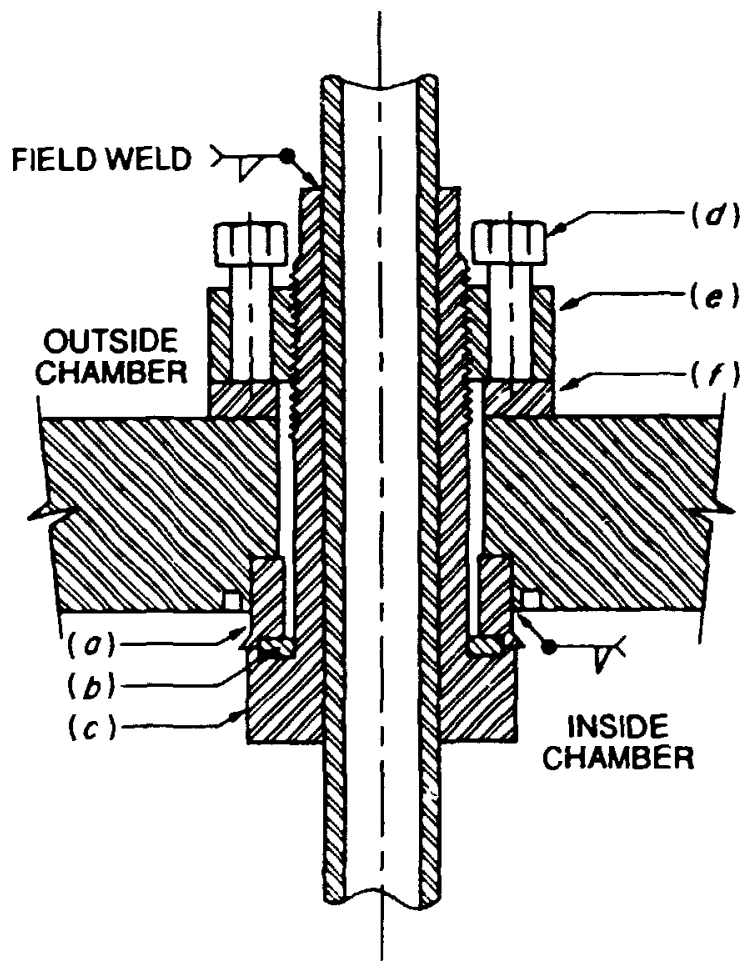

Fig. 1. Croses ecction of the aseambled eael, $(c)$ eal flange welded to the invide of vecuum chamber: (b) otandurd Conflet coppor gaeket; (c) ceal flange with extencion welded to fluid ine or tube; (d) jeckecrow; (o) pecking ring; (I) chrome-pleted thrust wacher.

circ-clip fitted into a machined groove. Tightening the jackscrews forces the two mating surfaces together, thus forming a seal. A chrome-plated thrust washer (f) between the or ter surface and jacking ring prevents the bolts from galling the chamber s outer surface. 
A minimum assembly diameter is maintained because the jackscrews are on the same radius as the sealing ring. which permits close spacing of the feedthroughs. In addition, no rotational torques are applied to the overall seal assembly during the sealing process, and no special keying or alignment is required for the reentrant seal or the overall assembly. The seal has a narrow sleeve section, which maintains some elasticity in the assembly and maximizes the clear aperture.

The prototype design criterion for use on the ATF was to generate a sealing force in excess of $2000 \mathrm{lb} / \mathrm{in}$. for the sealing surface. The properties of type 304 stainiess steel. considerations for a margin of safety, and the need to retain minimal spacing dictated the remaining dimensions. The feedthrough was tested with unlubricated, higil-strength screws and with lubricated, series 300 stainless-steel screws. Both types of bolts produced leaktight seals when torqued to 20 and 40 in. -16 . indicating a wide margin of sealing force. The assembly retained its seal (to $1 \times 10^{6} \mathrm{~atm} \mathrm{cc} / \mathrm{s}$ He) after $2 \mathrm{~h}$ in an oven at $250^{\circ} \mathrm{C}$. In addition. the seal can be broken and reassembled using the same gasket. Criteria can be established for any feedthrough diameter and suited to standard Conflat flange sizes.

\section{Additional information:}

Office of Tectnology Applications Martin Mariotto Energy Syotems, inc. P.O. Box 2008

Oak Ridoe, TN 37831-6257

Tolophona: (615) 574-4192; FTS 624-4192

P. H. Edmonde and W. D. Shipley, "A Reentrent Bekeble Al-Motal Feodthrough Vecuum Seal," J. Vac. Sai. Technol. A Q11) (1988), 165-67. 


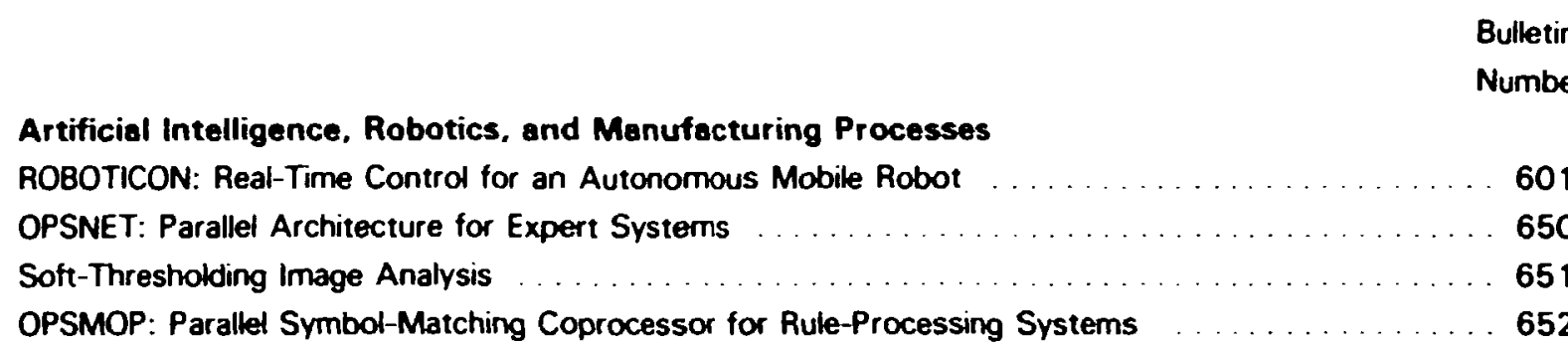

Measurements and Controls

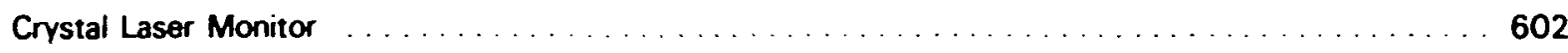

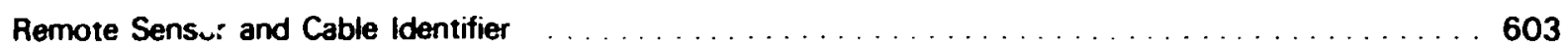

Portable, Surface-Enhanced Raman Spectroscopy System . . . . . . . . . . . . . . . . . 604

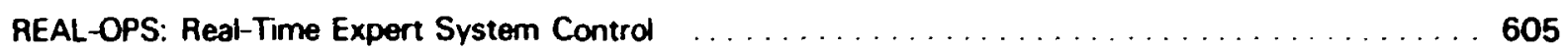

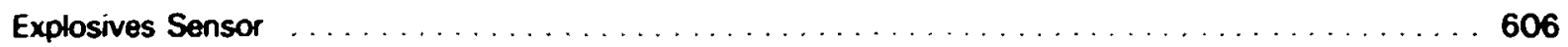

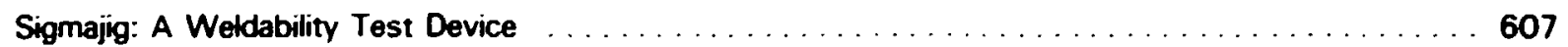

Motor Current Signature Analysis Process $\ldots \ldots \ldots \ldots \ldots \ldots \ldots \ldots \ldots \ldots \ldots \ldots \ldots . \ldots \ldots . \ldots \ldots$

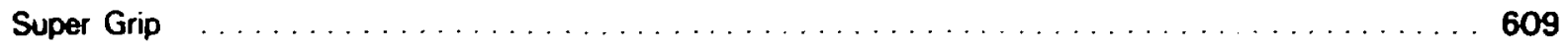

Differential Mechanical Properties Microprobe $\ldots \ldots \ldots \ldots \ldots \ldots \ldots \ldots \ldots \ldots \ldots \ldots . \ldots \ldots 10$

Ultrasonic Techniques for the Evaluation of Ceramic Joints $\ldots \ldots \ldots \ldots \ldots \ldots \ldots \ldots \ldots \ldots \ldots$

Advanced Software for the Efficient Manufacture of Complex Industrial Castings . . . . . . . 612

Atmospheric-Sampling Glow Discharge Ionization Source $\ldots \ldots \ldots \ldots \ldots \ldots \ldots \ldots \ldots \ldots . \ldots \ldots 25$

APIS: An Acoustical System for Identification of Subspecies of Honeybees $\ldots \ldots \ldots \ldots \ldots \ldots 6$

An Accurate Laboratory Test System Using Commercial Equipment

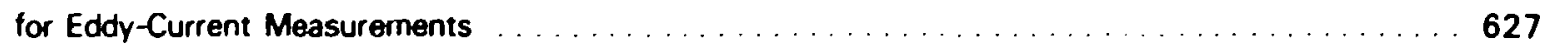

Californium-Source-Driven Subcriticality Monitor $\ldots \ldots \ldots \ldots \ldots \ldots \ldots \ldots \ldots \ldots \ldots \ldots$

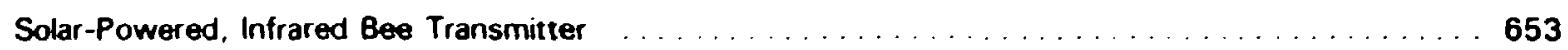

Nondestructive Testing with Pulsed Eddy Currents $\ldots \ldots \ldots \ldots \ldots \ldots \ldots \ldots \ldots \ldots \ldots \ldots$

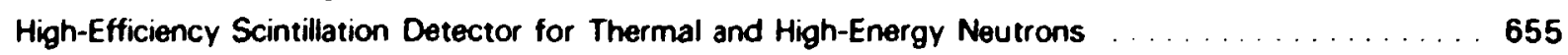

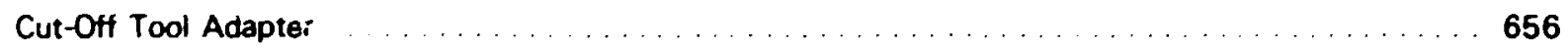

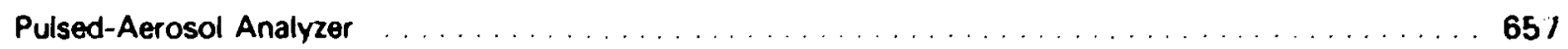

Strain-Gaged Bolt Process for the Direct Measurement of Valve-Stem Thrust $\ldots \ldots \ldots \ldots \ldots \ldots 6$

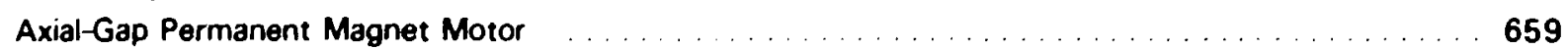

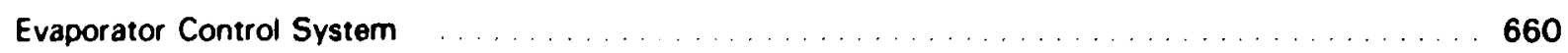

Modical and Biomedical Technology

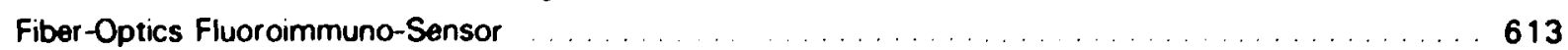

Information Science

Implementing and Managing Change: A Guide for Assessing Information Technology . . . . . . . 629

\section{Energy Conservation}

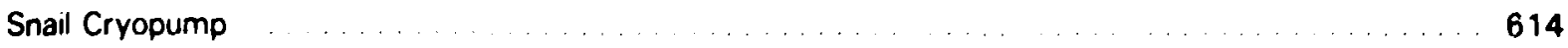

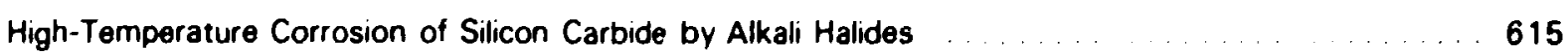

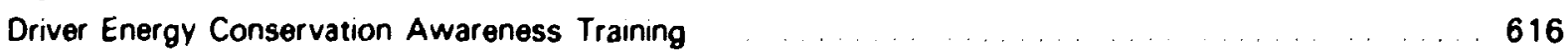

Horizontal Ground-Coil Heat Exchangers $\ldots \ldots \ldots \ldots 17$

Energy and Economic Efficiency Alternatives for Electric Lighting in Commercial Buildings _.. _ 618

Mor: ioring of Residential Groundwater-Source Heat Pumps the Northeast $\quad \ldots 19$

Single-Family Building Retrofit Research $\quad 630$ 
Energy Measurements Of Single-Family Houses

Passive Solar Structures Enhanced with Phase-Change Materials $\ldots \ldots \ldots \ldots \ldots \ldots \ldots \ldots \ldots .6 \ldots \ldots 2$

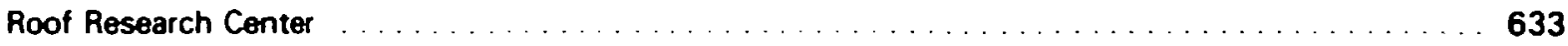

Assessment of the Energy-Savings Potential of Building Foundations Research $\ldots \ldots \ldots \ldots \ldots 64$

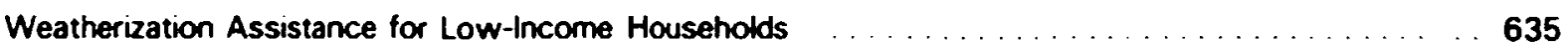

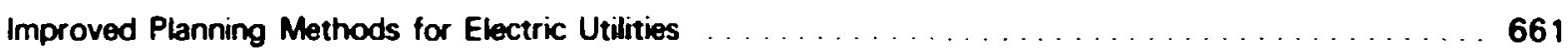

Residential Energy Conservation Shared-Savings Program $\ldots \ldots \ldots \ldots \ldots \ldots \ldots \ldots \ldots \ldots . \ldots 62$

Flow Regimes of Retrigerant Mixtures Condensing Inside Tubes $\ldots \ldots \ldots \ldots \ldots \ldots \ldots \ldots \ldots .6 \ldots$

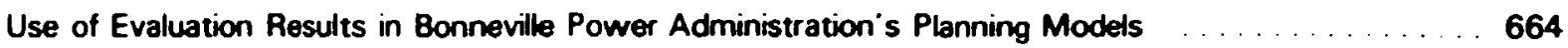

Energy-Conserving Retrofit Audit for Single-Family Buildings $\ldots \ldots \ldots \ldots \ldots \ldots \ldots \ldots \ldots \ldots$

\section{Environmental Technology}

Oak Ridge National Environmental Research Park $\ldots \ldots \ldots \ldots \ldots \ldots \ldots \ldots \ldots \ldots \ldots \ldots$

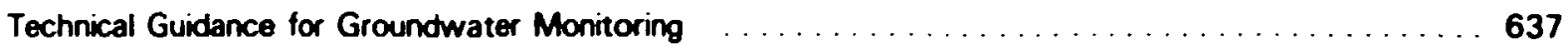

Ecological Research Needs at Hazardous Waste Disposal Sites $\ldots \ldots \ldots \ldots \ldots \ldots \ldots \ldots \ldots . \ldots 638$

Treatment of Low-Level Radiaactive Waste from Commercial Nuclear Reactors $\ldots \ldots \ldots \ldots \ldots .639$

A Three-Dimensional Finito-Element Model of Water Flow

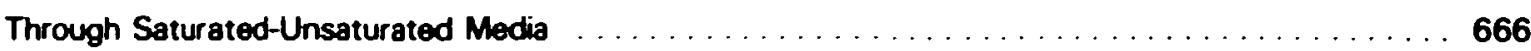

\section{Chemical and Waste Manegement}

Two-Pot: A Simplified Process for the Extractive Distillation of Nitric Acid $\ldots \ldots \ldots \ldots \ldots \ldots \ldots 60$

Update of Acute and Chronic Aquatic Toxicity Data for Heavy

Metals and Organic Chemicals Found at Hazardous Waste Sites $\ldots \ldots \ldots \ldots \ldots \ldots \ldots \ldots 61$

Treatment of Solvent Extraction Solvents with Activated Alumina $\ldots \ldots \ldots \ldots \ldots \ldots \ldots \ldots \ldots 642$

Chemical Hazard Information Profile of Tripheny Phosphite $\ldots \ldots \ldots \ldots \ldots \ldots \ldots \ldots \ldots . \ldots \ldots$

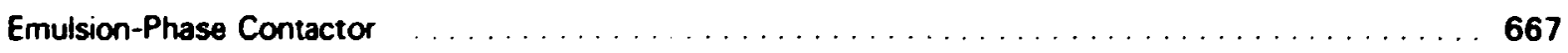

Grout Fixation of Variable Phosphate/Sulfate Waste $\ldots \ldots \ldots \ldots \ldots \ldots \ldots \ldots \ldots \ldots$

\section{Energy Production}

Determination of Effects of Atmospheric Contamination on

Photovoltaic Cells in Concentrating Systems

Study to Assess the Effects of High-Altitude Electromagnetic

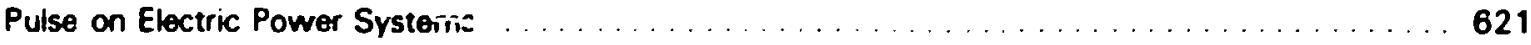

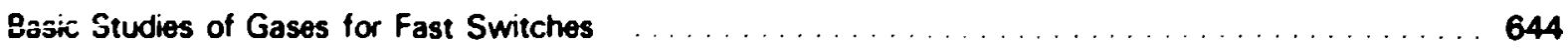

Elastomer Pump Seals for Coal Liquefaction Applications $\ldots \ldots \ldots \ldots \ldots \ldots \ldots \ldots \ldots \ldots \ldots$

A Process-Inherent, Ultimate Safety Boiling-Water Reactor $\ldots \ldots \ldots \ldots \ldots \ldots \ldots \ldots \ldots \ldots .669$

\section{Advanced Materials}

Lead-Indium Phosphate and Lead-Scandium Phosphate Glasses for Optical Applications $\ldots \ldots \ldots .622$

Active-Substrate Brazing Process $\ldots \ldots \ldots \ldots \ldots \ldots \ldots \ldots \ldots \ldots \ldots \ldots \ldots \ldots$

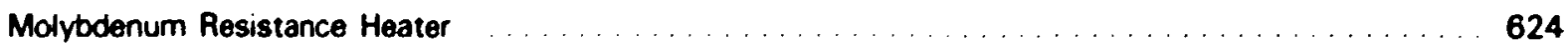

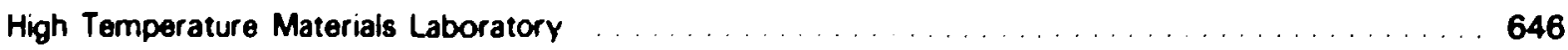

Advanced Process for Fabricating Optical Devices and Waveguides,

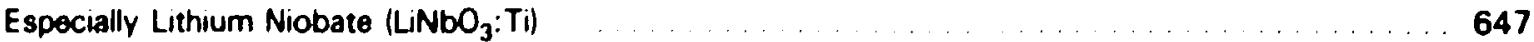

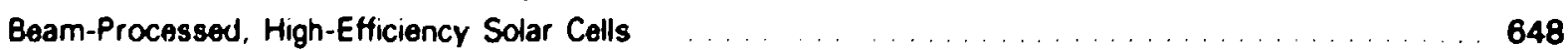

Process for Woar Inhibition of Artificial Hips and Knoes by lon Implantation . . . . . . . . . ... 649

Nickel-Iron Aluminides for Advanced Coal Conversion Systems $\ldots \ldots \ldots \ldots \ldots \ldots \ldots$

$X$-Ray Methods for Analyzing Rough Wear Surfaces $\ldots \ldots \ldots 71$

Platinized Chloroplast: A New Bioelectronic Material …... 672 
The Martin Marietta Energy Systems. Inc.. Office of Technology Applications publishes Teihnolugy teplications Bulletins three times a year. If you would like to be put on the mailing list. fill out and return one of the attached cards. A spare card is provided in case you know of a colleague who rould also like to receive the bulletins.

Yes, place my name on the mailing list to receive Technology Applications Bufletins. (Please type or print the following information.)

Name Title

Company

Address

City State and Zip

My interest areas are

D Artificial intelligence, Robotics, and Manufacturing Processes:

D Measurements and Controls:

D Medical and Biomedical Technology;

$\square$ Information Sciance;

Q Energy Conservation:

D Environmental Technology:

Transportation:

Aadioactive Materials;

Chemical and Waste Management;

$\square$ Energy Production; and

$\square$ Advanced Materials.

I am interested in licensing new technologies.

\section{$2 / 89$}

Yes. place my name on the mailing list to receive Technology Applications Bulletins. (Please type or print the following information.!

Name Title

Company

Address

City State and Zip

My interest areas are

D Artificial Intelligence. Robotics. and Manufacturing Processes:

C Measurements and Controls:

D Medical and Bi:medical Technology:

[. Information Science:

D Energy Conservation:

[ Environmental Technoloyy

Transportation;

$\square$ Radioactive Materials:

$\square$ Chemical and Waste Management:

[. Energy Production; and

[] Advancerd Materials.

r; 1 am interested in licensing new technologyes 
This report wes prepered es en eccoum of work sponeored by en apency of the United States Government. Noither the United Stated Government nor any acency thereof, nor any of their employeses, makes any werranty. expreas or impliod, or ascumes any leal liability or responebility for the scarrecy. comt pletenese, or uenfunese of amy information, apparatue. product, or proceses disclowed, or represents that its weo would not intringe privatidy owned rights. Reterence herein to any epecific commerciel product, proceses, or eavice by trede nams, tredenark, manufecturer, or otherwies, does not neceesierily conetitute or imply its endoreoment, recommendation, or favoring oy the United Sutes Governmem or any eqency thereot. The views and opinions of euthors expreseed herein do not necescerity etate or reflect thoes of the United Stuties Government or any equncy thereof.

This document was prepared under the sporizarship of the U.S. government by Martin Marietta Energy Systeris, Inc., under contract No. DE-ACO5-84OR21400. Nither the government nor any person acting on its behaff assumes any liability from the use of this information or warrants that this use will be free from privately owned rights. 